\title{
Ulrich von Liechtenstein's Service of Ladies
}

Translated by J.W. Thomas 
Ulrich von Liechtenstein's Service of Ladies 
From 1949 to 2004, UNC Press and the UNC Department of Germanic \& Slavic Languages and Literatures published the UNC Studies in the Germanic Languages and Literatures series. Monographs, anthologies, and critical editions in the series covered an array of topics including medieval and modern literature, theater, linguistics, philology, onomastics, and the history of ideas. Through the generous support of the National Endowment for the Humanities and the Andrew W. Mellon Foundation, books in the series have been reissued in new paperback and open access digital editions. For a complete list of books visit www.uncpress.org. 


\section{Ulrich von Liechtenstein's Service of Ladies}

TRANSLATED BY J. W. THOMAS

WITH AN INTRODUCTION BY KELLY DEVRIES

UNC Studies in the Germanic Languages and Literatures

Number 63 
Copyright (C) 1969

This work is licensed under a Creative Commons CC BY-NC-ND license. To view a copy of the license, visit http://creativecommons. org/licenses.

Suggested citation: Thomas, J. W. Ulrich von Liechtenstein's Service of Ladies. Chapel Hill: University of North Carolina Press, 1969. DOI: https://doi.org/10.5149/9781469658520_Thomas

Library of Congress Cataloging-in-Publication Data

Names: Thomas, John Wesley.

Title: Ulrich von Liechtenstein's Service of Ladies / by John Wesley Thomas.

Other titles: University of North Carolina Studies in the Germanic Languages and Literatures ; no. 63.

Description: Chapel Hill : University of North Carolina Press, [1969] Series: University of North Carolina Studies in the Germanic Languages and Literatures. | Includes bibliographical references. Identifiers: LCCN 70633196 | ISBN 978-1-4696-5851-3 (pbk: alk. paper) | ISBN 978-1-4696-5852-o (ebook)

Classification: LCC PT1564.F7 E57| DCC 831/.2 


\section{Contents}

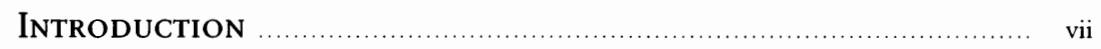

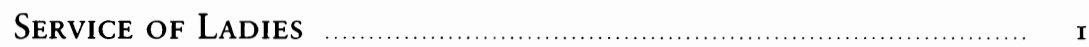

The First Dance Tune ....................................................... r $_{3}$

The Second Dance Tune .................................................. I9

The Adventure of How Sir Ulrich First Spoke With His Lady ............ 2 I

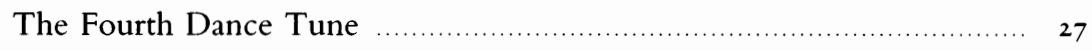

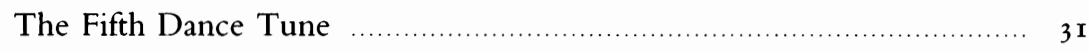

The Adventure of How Sir Ulrich Lost His Finger ........................ 33

The Adventure of How Sir Ulrich, Dressed as a Queen, Rode Tourneying

Through the Lands ..................................................... $4_{4} 8$

The Adventure of How Sir Ulrich Came as a Leper to His Lady and of

How He Saw Her .......................................................... r 30

The Sixteenth Tune, a March ............................................ 160

The Twentieth Dance Tune ................................................ I63

The Twenty-First Dance Tune ............................................ 164

The Twenty-Eighth Dance Tune ......................................... I 67 



\section{THE REAL ULRICH VON LIECHTENSTEIN ${ }^{1}$}

In the recent popular movie $A$ Knight's Tale (Columbia Tristar Pictures, 2001), when Geoffrey Chaucer (Paul Bettany) heralds the tournament appearance of poor-squire-turned-tournament-champion William Thatcher (Heath Ledger) as Ulrich von Liechtenstein, a new cinematic hero was born. In the movie, Ulrich's tournament victories pile up and pile up until he wins the world championship against the great and extremely malevolent French champion, Count Adhemar (Rufus Sewell)... and, of course, he wins the noble girl, Jocelyn (Shannyn Sossamon). However, this was not the first Ulrich von Liechtenstein in history, nor could it ever be said that $A$ Knight's Tale's Ulrich von Liechtenstein was more cinematic than the medieval one!

The real, the medieval Ulrich von Liechtenstein was born around 1200 however in Styria, in what today is southern Austria. He was the son of noble parents, hence the von in his name, but there is no record of his being the eldest son or heir to his father's nobility. Still, Ulrich's nobility meant that he would be well educated. This education consisted of all the arts and letters popular during his time, perhaps even the seven liberal arts. He certainly learned to read and write, in his own vernacular dialect if not also in Latin, and perhaps also in Medieval French and Italian. His own later writings were written in what is now called Middle High German, but show signs of a knowledge of these other Romance languages. Yet Ulrich von Liechtenstein would be schooled in other arts befitting his class and status. He would have learned martial arts: how to fight with different arms and armor, on horseback and on foot. Unlike many of his noble counterparts, Ulrich would combine all of this education together, providing the twenty-first century medieval enthusiast with an example of one of the most celebrated jousting poets or, perhaps, poetic jousters the world has ever known.

The early thirteenth century of Ulrich von Liechtenstein's youth was one of relative peace. The Crusades were still being fought, but after the fall of Constantinople to the Latin soldiers of the Fourth Crusade, later crusading endeavors became less European-wide and more individual. Crusades would still be waged, but by separate kings and princes, such as Emperor Frederick II and King Louis IX, and sometimes even without the permission of the papacy. This meant that the general call for western European Christian warriors to fight in the Holy Land which had always been sent previously from Rome was quieted. Noble soldiers were still required; no one who wished to participate on Crusade would be turned away. But there was certainly less pressure for 
men like Ulrich von Liechtenstein to travel to the Holy Land for much of their youth. Like other young warriors of his time and region, Ulrich appears to have promised to go on Crusade, but, also like these other young warriors, he never went.

There was also no warfare in Austria, Italy, Switzerland, or any of the southern German principalities during the early thirteenth century. This was a good thing, of course, and quite rare for the Middle Ages. But it also meant that young would-be warriors had difficulty in practicing their martial arts. It also meant that many of them had few ways of acquiring knighthood, their most sought after goal. Most, it is true, would have served their fathers, uncles, cousins, or, perhaps, non-relatives as pages and squires. But they would usually have needed to show some type of valor during combat to earn their knightly spurs. At times a special occasion might suffice to allow young men unable to prove themselves in warfare to become a knight. So it was for Ulrich von Liechtenstein. As a young boy he served as a page, and as a young man as a squire, the latter between 1215 and 1219 to the Markgraf (or Marquis) Heinrich von Istria. And in 1222, at the occasion of his daughter's marriage, Duke Leopold of Austria, granted Ulrich von Liechtenstein's greatest wish when he made him, and 199 other young warriors, a knight.

Where young thirteenth-century knights and squires practiced their skills during times of peace, and sometimes also during times of war, was the tournament. A tournament might be held for any reason, sometimes to celebrate a special event and sometimes only to hold a sporting event. Actually, there was not a single "tournament" at this time, but a number of different types of tournament. One of these types was the mélée. This really was the tournament proper, where two "armies" vied against each other in a mock battle fought on a tournament plain. These armies would consist of both cavalry and infantry soldiers; even archers might take part. All weapons could be permitted in this mock battle, although of course they would be blunted. A cavalry charge would initiate the mélee, with further warfare between all of the forces continuing until one "army" was declared the victor.

A second type of tournament was the joust or tilt. This was a one-on-one combat fought on horseback. It also generally took part on a tournament field, although this field would of necessity be narrowed until there was but a double lane divided by a barrier. The jousters would approach each other on opposite sides of this barrier, dropping their lances at the last moment in an effort to break them against their opponent's armor. Points would be given for whether and where these lances struck, and special effects -- lances breaking in a "cinematic" way - might bring extra points. Unfortunately, no thirteenthcentury lance has survived, but it is known that they were blunted. Some historians also wonder if sometimes these weapons were not cut or trimmed by their users in order to increase the effect. 
Although single jousts were known, in a tournament situation several jousts would be held during which the participants might be decreased as they lost. Ultimately, only the final two jousters would face off against each other in one final match to decide the tournament championship. Every rider would therefore need to fight several jousts before he could win the top prize, which was generally given by the tournament sponsors, although often awards were given by the participants to their victors in the form of ransom for their "lost" horses and armor. In some tournaments the more professional jousters might be "seeded", meaning that they would be able to skip some of the preliminary rounds of the meet.

Of course, each tournament participant would wear their finest armor, in this case a full coat of chain armor covering all extremities, with chain-mail mittens and boots to cover the hands and feet, and a mail coif to cover the neck and head. Atop this would sit the warrior's helmet, likely a Great Helm. He would also carry a shield; on this and on his horse's barding would be his heraldic decoration, identifying the rider's nobility and lineage. This can be seen in Ulrich von Liechtenstein's portrait painted as a manuscript illumination during the early fourteenth century by an anonymous illustrator (Heidelberg, Universitätsbibliothek, MS Cod. pal. Germ 848, f.237; see cover illustration) which, although painted later, fairly correctly portrays the arms, armor, and even possibly the heraldry of the previous century.

Ulrich von Liechtenstein was a champion jouster. How do we know? Because he told us. This should not be seen as egotistical, however. Chroniclers might be interested enough to record the holding of a tournament and the event which prompted it, but they rarely report the participants or even the winners. Instead, most of the great jousters of the day are mentioned in chivalric tales, poems and prose romances, which almost as a matter of course included at least one tournament. Ulrich von Liechtenstein not only appears in one of these, but in fact he wrote it. And it was quite good, and seemingly quite popular. Its title is Frauendienst, or in English translation, The Service of Women.

Ulrich von Liechtenstein is the hero of Frauendienst. In it he tells his story, as a knight and a jouster. As a boy of twelve Ulrich fell in love, or at least he realized that the greatest happiness and honor for a knight came in the service of a woman, so Ulrich chose one. She was a beautiful noble woman, older and more noble than he was, and she was married, but in the tales of love and chivalry that hardly mattered. What did matter was that she initially spurned his advances. Of course, Ulrich von Liechtenstein was still a child at the time so this did not come as a surprise to him, but he also used this rejection, in the way so may other authors had done and would continue to do, to recognize that his goal, the winning of his lady's heart, would come only after a life full of obstacles, frustrations, and adventures. He would have to earn her love. 
From age twelve to age seventeen, as he grew into manhood, Ulrich von Liechtenstein adored this lady from afar. He managed to stay close by her, however, by becoming a page in her court. As such, he was able to touch what she touched and cherish the things that were hers. He writes that sometimes he stole into her chamber after she had bathed so that he could wash his hands in her water; on some of these occasions he would even drink from her bath.

Once he learned to joust he found that he had a new means of expressing his love for his lady. He would enter tournaments wearing her colors. It is hard to know at this stage if his unnamed love interest was aware of Ulrich's advances. Certainly she must have seen Ulrich von Liechtenstein, once her page, wearing her colors and participating in tournaments. She may even have seen him stealing out of her chamber after her baths. If so, she did nothing to encourage his continuing interests, but little also to stop them. That was until, after he had gained a few tournament victories, Ulrich asked his niece to approach the lady as a mouthpiece for his affection. His lady would not listen to Ulrich's love appeals. She told his niece that she was repulsed by her uncle's appearance, that he had a harelip, and that he was lower-born than she.

Such a rejection still did not stop Ulrich von Liechtenstein's pursuit of the lady. He had his harelip removed by surgery, recuperated - for six weeks and wrote a love song for her. This softened her a little, and she allowed Ulrich to attend a riding party in which she was present, indicating to him that should he ride close to her they might have a chance to talk. He joined the party but when he rode close to his beloved he became so nervous that he could not say a word to her. Again she spurned him, this time tearing a lock from his hair to emphasize her rejection of him.

Ulrich von Liechtenstein returned to the tournament circuit, all the time fighting not only for victories in the mélée and joust but also fighting for the love of this beautiful woman. But for three years she would not even allow him to fight in her name nor to carry her colors. He constantly sent her letters and poems, but these were ridiculed and rejected by her. In one letter he claimed that he had wounded a finger in a joust fought that day; she derided him, saying that he exaggerated the severity of his wound. In response, Ulrich cut off one of fingers and sent it to her. With this gesture, his lady finally gave in, writing back that she would look at his severed digit every day and remember the sacrifice he had made for her.

Having won some affection from her, Ulrich von Liechtenstein determined that an even larger display would win her over entirely. He decided that he would fight a series of jousts from Venice to the borders of Bohemia. This he called the Venusfahrt (Venus Journey), in honor of that goddess of love and of all women. To further spotlight this trek, Ulrich would dress as "Lady Venus" both in the joust and when not fighting. He does not record how he pulled off such a stunt, although he does insist that no one saw through his feminine 
disguise. However unlikely this was, and Ulrich does write that his appearance as Venus at times aroused quite a bit of laughter, the chance to fight a joust interested many nobles along his path. During the five week period of the Venusfahrt Ulrich claims to have broken 307 lances with opponents, fighting sometimes eight jousts in a day. Should an opponent be successful in breaking his lance on Ulrich, in other words actually hitting Ulrich's armor, he would be presented with a ring. 271 of these rings were awarded during his journey.

At the end of his Venusfahrt Ulrich von Liechtenstein returned to his lady, hoping that his spectacle would have appealed to her. She knew that he had undertaken the Venusfahrt, and she had sent word to Ulrich that she wished to speak with him. However, she instructed the love-smitten knight to come to her dressed as a leper and to sit with the other lepers begging outside her door. When he was so attired she passed by Ulrich but did not greet him, instead making him sleep outside in the rain. The next morning she sent a message to this "beggar" that he could climb the rope to her bedroom window, but, after he had further fulfilled her instructions by wading across a lake, as he ascended the rope his lady unhooked it and Ulrich fell into the foul moat below. Ultimately, it was only after Ulrich von Liechtenstein promised his lady that he would go on Crusade in her name and began to prepare for such a venture that she called it off and offered him her love.

What symbols, tokens, or acts these were is not indicated by Ulrich in Frauendienst. One hopes that it was worth it in the end, for the poor knight, it seems, had been made to perform the most difficult of tasks to earn this woman's favors. However, it was not as if he was without female companionship. It appears that Ulrich von Liechtenstein was married throughout most of these chivalric displays. On one occasion during the Venusfahrt he stopped off for three days to be with his wife. He also reports that she was quite good at managing his estate and raising his children. So there must have been something more. His lady had become a symbol for the great jouster. She was a symbol of the honor and love for women that he held as such a principle for his and seemingly every other young nobleman's life.

Then there was the tournament. His lady became a means for Ulrich von Liechtenstein to participate in tournaments. This was a sporting pastime that not only displayed chivalric valor and fighting skill, but it was fun, too! It appears that young knights of Ulrich's ilk wanted to fight mélées and jousts whenever and wherever they could. So enthusiastic were they, Ulrich writes, that when, gathered together for negotiations between the lords of Istria and Neustria, the opportunity arose to joust at Freisach in May 1224, at Ulrich's urging, the peace conference was held up until a full-scale tournament could be organized.

By the Venusfahrt, Ulrich von Liechtenstein had given up the mélée. He was too good and too well known to participate in that form of tournament any 
longer. Although well armored, tournament injuries could still happen, and it is clear that as a well-known jouster Ulrich may have been singled out for particular attention by any number of younger men willing to gain their own renown at the expense of his own. This may also have been the reason why he fought the Venusfahrt in disguise. Still, it is difficult to know how anyone could miss the great jousting knight's style of fighting on the tiltyard. Nor does it seem that they could miss the participation of his entourage in the processions leading up to the jousts which he was to fight in. In these processions large heraldic banners would be flown, musicians would play, squires would bear lances, and knights would parade through town to the tournament field. At Neunkirchen during the Venusfalirt, Ulrich reports, more than one hundred knights, their squires and banners, marched and rode to the tournament. At times the procession was not large, such as at Korneuburg, also during his Venusfahrt, only a single bugler and one banner paraded before him onto the field, although then, perhaps in order to make this procession longer, Ulrich had his pieces of armor also carried in piece by piece.

In later life Ulrich von Liechtenstein continued to joust. In 1240 he organized another large series of jousts which he called the Artusfahrt (Journey for Arthur) in which he would again joust against all comers. The jousters would naturally not fight under their own names but instead would carry the names of Arthur's greatest knights, Gawain, Lancelot, etc. Should an opponent break three lances against him, he would have a right to join Ulrich's "Round Table," a special chivalric circle the joining of which would bring the honor that later in the Middle Ages would be reserved for members of Chivalric Orders such as the Golden Fleece or the Garter. Again Ulrich von Liechtenstein traveled throughout the lands near to his home, jousting to his and his opponents' hearts' content; on one occasion, at Neustadt, after the Artusfahrt joust was set up for a fortnight's time, the intervening time was spent by Ulrich and his fellow knights, of course, in jousting. Unfortunately, the final joust of the Artusfahrt was delayed and then banned altogether by Duke Frederick of Austria. His reasoning: political events meant a need for cautious sobriety rather than celebratory sport.

In later life, when he had retired from jousting, Ulrich von Liechtenstein played several minor political roles in Styria and Austria. As an administrative official, a ministerialis, Ulrich had some power to wield, although not enough to strike out on his own. Instead, he submitted to those whom he wisely thought could benefit and protect him. In 1250 this was the archbishop of Salzburg, with whom Ulrich made a military treaty to provide soldiers and castles for the archbishop; in return, Ulrich gained the archbishop's blessing of the marriage between two of Ulrich's children and two of the archbishop's richest ministeriales' children. In one of these marriages, Ulrich von Liechtenstein's son and heir, Ulrich, married Cunegunde of Goldegg, the daughter of the rich 
and powerful Conrad of Goldegg, thereby ensuring his father's name and legacy. Liechtenstein today remains as free and independent as its jousting namesake so many years before.

Was this all true? Did Ulrich von Liechtenstein really take part in all of the tournaments he said he did, sometimes dressed as Venus and sometime calling himself Arthur? Do we really care? After all, half the fun of having a cinematic hero, in this case the real Ulrich von Liechtenstein, is not knowing if all his adventures are real or fiction.

\footnotetext{
'This article originally appeared in Medicval History Magazine, 1 (Sept 2003), 34-39. Because of the medium, no footnotes appeared with the article originally; nor was there a bibliography with the article, except in the Middle High German edition of Frauendienst (ed. Franz Viktor Spechtler [Göppingen: Kümmerle, 1987]), and a modern German translation of it by same Middle High German editor (Klagenfurt: Wieser Verlag, 2000). This is because, despite the interesting character that Ulrich von Liechtenstein was historically and literally, despite the existence of the famous manuscript illumination depiction of him, portrayed with his rather exaggerated female headpiece (Heidelberg, Universitätsbibliothek, Ms. Cod. pal. Germ. 848, f.327), and despite the fact that nearly every historian of chivalry refers to Ulrich and his role in the history of tournaments and jousting, not much more is known about him than he writes about himself. Of course, this, as every historian knows, means that the credibility of the source is somewhat suspect. Or does it just add to the playfulness of a medieval tale understood in the atmosphere of merriment and celebration, as all historical, literary, and artistic sources suggest the tournaments were supposed to be?

For a recent collection of studies on Ulrich von Liechtenstein's literary corpus see Ich, Ulrich von Liechtenstein: Literatur und Politik im Mittelalter: Akten der Akademie Friesach "Stadt und Kultur im Mittelalter," Friesach (Kärnten), 2-6, September 1996, ed. Franz Viktor Spechtler and barbara Maier (Klagenfurt: Wieser, 1999). On the history of chivalry and tournaments see Maurice Keen, Chivalry (New Haven: Yale University Press, 1984); Richard Barber, The Knight and Chivalry, 2nd ed. (Woodbridge: The Boydell Press, 1975); Richard Barber, The Reign of Chivalry (New York: St. Martin's Press, 1980); Richard Barber and Juliet Barker, Tournaments: Jousts, Chivalry and Pageants in the Middle Ages (New York: Weidenfeld and Nicolson, 1989); and Das ritterliche Turnier im Mittelalter: Beiträge zu ciner verglecihenden Formen- und Verhaltensgeschichte des Ritertums, ed. Josef Fleckenstein (Göttingen, Vandenhoeck \& Ruprecht, 1985).
} 

SERVICE OF LADIES 

I greet the ladies, one and all, though my reward was ever small for serving them, I must confess. What wealth of virtue they possess! They're all the world can have of bliss, for God made nothing else like this: a noble woman. That is why my praise of them must be so high.

You must admit it, for it's true, none give the honor that is due to woman's goodness, though their praise outstrips the light of summer days. Where does the sunlight start and end? If one on whom I can depend can tell me that, then I'll declare that he has travelled everywhere.

Their splendor lights up every land; I do not know what distant strand may mark the limit of their splendor! Each word must change and be more tender, each passing year must leave the earth more fair before a woman's worth and goodness can be rightly heard, completely told in song and word.

How can the story be completed and all their virtues fully treated? There is no end of what to say. And when the world shall pass away the praise of women shall suffice for poets up in paradise. I fear, although I wish to speak their praise, my thoughts are all too weak.

Women are pure, refined are they, women are beautiful and gay, women can still love's deepest pain, women are never cruel and vain, women make kind and noble men. Well for him who deserves it when the women greet him as a friend! His sorrow and distress will end. 
Women are rich in charm and grace. To match their lovely form and face is more than angels hope to do. A woman, virtuous and true, who has no faults of any kind, must have an angel's heart and mind and like an angel seems to glow. You have my word that this is so.

My praise is finished. Now I plan to tell a tale as best I can and pray to God as I begin that I may interest you therein, that all will listen as one should, and all of you will think it good. My labors then will satisfy.

I swear the story is no lie.

When I was still a little child my fancy often was beguiled by what the poets sang and read and what the wise men always said: that none win fame who do not serve good women as they all deserve, but he who serves them with his sword and heart receives a rich reward.

This I heard the wise men say: none can be happy, none can stay contented in this world but he who loves and with such loyalty a noble woman that he'd die if it would save her from a sigh. For thus all men have loved who gain the honor others can't obtain.

I was a child when they spoke so and knew no more than children know, a hobbyhorse was still my steed; I was so simple then indeed, I thought, "Since lovely women raise a man to such esteem and praise, I'll serve the ladies faithfully however it may go with me. 
"I'll give my body, all my mind, and life itself to womankind and serve them all the best I can. And when I grow to be a man I'll always be their loyal thane; though I succeed or serve in vain I'll not despair and never part from them," thus spoke my childish heart.

While lost in thoughts like these I grew to twelve-I swear it all is true. I pondered everywhere I went just as my youthful fancy bent, and, asking questions, rode around wherever ladies could be found. Their ways, the customs they enjoy I learned while I was still a boy.

Whoever spoke of women's praise I followed, just to hear each phrase, for it would make my heart so light and fill me with a true delight. I heard from many a learned tongue their excellence and honor sung; they praised one here and praised one there, they praised the ladies everywhere.

I heard the virtues of them all but there is one whom I recall whose fame was spread on every hand. The best of singers in the land commended her and her alone. To whom her excellence was known, who knew her virtue and good name, would have to join in her acclaim.

She was extolled by knight and sage. I later was the lady's page and served her gladly four years throughwhat I am telling you is true. My youthful eyes could never see a thing in her which should not be, for she was always kind and good, the very flower of womanhood. 
My heart then spoke to me and said, "Dearest friend, if you are led to yield yourself to woman's spell and only live to serve her well, then she alone will ever do. This counsel I must give to you: since she's the one whom all prefer we ought to go and live with her."

"I'll do, my heart, as you advise, but do you think it would be wise for us to labor for the pay that lovely women give away? This woman whom I am to serve is far beyond what we deserve. She is too high for us, we'll gain but little for our work and pain.

"Heart, I'll swear an oath to this: as I may gain eternal bliss, I love her more than all the rest and more than self. At your request and in the hope that I may win her affection, I'll begin to serve my love this very day and ever after, come what may."

My heart and body then conspired to win the prize which both desired. I went to her with longing sighs and looked at her with loving eyes. I thought with joy, "Can this be she to whom I give my loyalty, with whom I'll stay while I have breath, who'll bring me happiness or death!"

I thought, "What can I do for her that will induce her to prefer me to the other noble boys whom she presently employs? If one should serve her better here then I would be despised, I fear. I just don't know what else to do but serve her late, and early too." 
Many times in summer hours

I would gather pretty flowers

in fields and meadows, everywhere, and bring them to my lady fair.

If she should take them in her hand my joy was all that I could stand. I thought, "Your fingers hold each stem just where I was holding them."

Great was my happiness when I could be with others standing by at meals and see the water poured on those white hands which I adored. I took the water secretly with which she washed away with me and, filled with love, I drank it all; because of this my grief was small.

I served her as a child, but well and more than I can ever tell. Whate'er a child can do or may I did for her until the day my father took me home again. $I$ learned of longing sadness then and knew the pain within my heart that lovers feel when they must part.

I had to leave but, unresigned, my stubborn heart remained behind and would not go with me from there. That surely was a strange affair, that I should rule my body so but could not force my heart to go. It stayed with her both night and day and had no rest from sad dismay.

Wherever I might walk or ride my heart was always by her side, and through the day and all night long my love for her remained so strong that I beheld her constantly.

Such was the love she won from me. No matter what the time or place, within my heart I saw her face. 
I'll speak no more of this. It brought me misery with every thought. While thus my heart and body warred I went to serve the noble lord of Istria, a knight whose worth was not surpassed in all the earth. Margrave Henry was his name; his virtue well deserved its fame.

He lived for honor; none has heard him ever speak an evil word. He was merry, he was bold, his knightly traits were manifold. He was loyal, he was true, and he was honest, through and through. He worshipped God and helped his friend; so lived the prince until the end.

He helped me, still a simple lad, to gain the knowledge which he had: to talk with ladies and, of course, to ride with skill on any horse, to write sweet phrases in a letterhe said, "I know of nothing better; it shows a young man is refined when he speaks well of womankind.

"Sweet words when joined to noble deeds are what a noble lady needs. I speak the truth and nothing less, that you can never have success with high-born ladies if you try to flatter with an empty lie.

You'll gain no more than disbelief and all your hopes will come to grief."

Had I been able to fulfil such noble deeds as was his will, I'd surely be a better man.

The years passed by as they beganfour years I longed for her and sighed. While I was there my father died and I went home, as those must do whom parents leave possessions to. 
My lord then gave me leave, and sent me forth so well equipped I went as proud as he, and looked as fine. I travelled then to Liechtenstein, my childhood home in Steierland. I found there many a youthful band which jousted. This was custom still; so young men learned this knightly skill.

When I found them jousting there I knew how I might win the fair and charming one whose love I sought. "If I'm to serve her," so I thought, "I'll do it as an errant knight. With sword and lance I'll boldly fight for her each day and never waver. God grant that I may win her favor."

I rode to many a tournament and tilted everywhere I went. Three years I wandered with my steed and then became a knight indeed. It happened in Vienna where a feast was held beyond compare, a wedding festival so grand that thousands came from every land.

Prince Leopold of Austria gave his lovely daughter to a brave and noble Saxon who desired her for his wife whom all admired. The festival would suit a queen; the like of it I've never seen at any wedding anywhere. It's nothing but the truth, I swear.

Those whom the worthy prince invitedtwo hundred fifty squires - were knighted with all due honor at the feast.

He gave a thousand knights, at least: vassals, barons, even counts, gold and silver, clothes and mounts. The prince did this, and all could see therein his noble majesty. 
Five thousand knights and maybe more ate from the goodly prince's store.

After melees dances came and many another knightly game.

The duchess and her retinue were there, her charming daughter, too. The host of lovely ladies' eyes upon us made our spirits rise.

The light of all my joy was there, my sweet and faultless lady fair. I saw her whom my heart preferred but still I could not say a word to her throughout the feast we had; because of this I long was sad. The watchers would not let it be; their spying quite discouraged me.

But when the sweet and lovely charmer saw me mounted, clad in armor, she addressed a friend of mine, "I think that it is really fine that yon Sir Ulrich was among those knighted. While still very young he was my page, some years agothe Knight of Liechtenstein, you know."

Later, when my friend told me and I found out how greatly she was pleased, then I was happy, too, and wondered thus, "Would she have you to serve her as a faithful knight?" The thought itself was true delight; it was sweet and it was goodI felt as proud as a young knight could.

Then came the festival's last day and each one went his separate way merrily from land to land. Tournaments on every hand to honor ladies were begun. I could not miss a single one but splintered lances everywhere because I loved my lady fair. 
I rode about and could attend

twelve tourneys ere the summer's end, and there was many a cavalier of note with whom I broke a spear.

'T was then I grew to man's full strength and learned the nightly skills at length so I was never overthrown.

For this I thank my love alone.

The joys of summer disappeared as soon as icy winter neared. Then I was forced, although so ill with love, to cease my warlike drillI'd suffered little pain thereby. I now was sad and knew not why. A longing sorrow came to me and seldom let my heart be free.

I felt the pangs of love in vain and could not tell her of my pain, which often filled my heart with woe. My ladylove was guarded so that never did I have a chance to tell her with a word or glance that I had always loved her best, more than myself and all the rest.

They would not let me see her ever, and so it was that I could never disclose to her what I would say. This made me sadder, day by day, like any other lovesick man. I had no messenger or plan to tell her what my wishes were and of the love I had for her.

Shall I reveal my suffering and not conceal a single thing: she didn't even know that I was serving her with deed and sigh. I often went to bed in sorrow and nursed my pain until the morrow, arose still burdened down with care and took it with me everywhere. 
I was the gloomiest of men, but only hear what happened when I stopped once at a citadel.

The master there received me well with all the honor that was due. His wife, my aunt, was friendly, too. "My dearest nephew," she spoke thus, "you are most welcome here with us."

My aunt soon took me by the hand. I followed at her soft command to where no one could hear a word. Now listen, this is what I heard: "I'm pleased to see you once again; now won't you tell me how you've been? Have you been feeling good, or bad? If you've been happy, I am glad."

She smiled and said, "You make me laugh; what women say on your behalf I'll tell you, though you shouldn't know. I travelled several days ago to see a friend, a lady who, while we were talking, mentioned you. She asked how you and I were kin and I explained the truth therein.

"She then continued, 'It's been said, . . . . . [line missing] . . . . . that this young knight speaks always good of women, as a noble should. He'd like to serve, the rumor goes, a certain lady whom he knows. His service, should it prove a fact, will surely be a knightly act.'

"I spoke, ' 'T was also said to me that he admires a lady. She is more to him than all the rest, more than the life within his breast. But who she is, I cannot say, although he praises her each day and tells that she is good and kind and has a pure and noble mind.' 
"Suddenly she begged that I

should speak at once with you and try

to learn her name whom you prefer.

I ask because I promised her and said, I'd quickly let her know and would not wait or let it go.

Now save me, nephew, from her blame and tell me, what's the lady's name?"

"But, auntie, you should know full well, the lady's name I'll never tellat least I won't till I have heard you promise not to breathe a word to anyone of this affair.

And also I must hear you swear that you will be my messenger and make my service known to her."

"I'll bear no messages for you but I will swear, whate'er I do, by God and all my hopes of bliss, I'll never say a word amiss;

for you deserve as much, I'm sure.

With me her name will be secure.

If I can help in any way

all you need to do is say."

60

"I must tell you, I'm afraid,

for I can really use your aid.

It's this lady friend of yours

whom indeed my heart adores, who's my delight and my desire, she who asked you to inquire what my lady's name might be; that best of women, it is she."

"I can't believe what you have saiddear friend, you've truly been misled. For you she's much too highly born; you'll only gain her wrath and scorn. You cannot be successful there, so hear my counsel and forbear. It's best that you give up this thought of serving her. 'T will come to naught." 
"Whether joys or cares come thronging, I'm so overcome with longing and love that I shall have to try to serve her, even though I die while in her service. You will find that you can never change my mind. I'll serve my lady with each breath and faithfully until my death.

"If you won't come to my support or render aid of any sort then all my joy will turn to pain and life itself will be in vain. Would you prevent such misery, then you must tell her this from me: It's she I love. Without design I offer her this heart of mine."

"Nephew, what more is there to say? God grant that you will get your way and that the lady will be kind.

I'll tell her what is on your mind and not withhold a single thing. In several hours I can bring your message and can tell her of your wish to serve her and your love."

"In reverence at your feet I kneel. Lady, I shall always feel thankful if your lips will tell my lady I shall serve her well, that I shall be her own true knight, and that my heart and soul and might belong to her. I'll freely give them all as long as I shall live.

"I've sung a new and pretty song of her, which you must take along with you and bring it to her ear and, on returning, let me hear if she believes the song is good. I praise her always, as I should and as I've done since I was young. Her virtues can't be fully sung. 
"God bless you, aunt, for what you do."

"I hope He does the same for you."

"Now you must do your best for me."

"Trust only in my loyalty."

"By your leave, I now must go."

"May God protect you, friend." And so

I parted from my aunt, but sent

this song with her before I went.

\section{THIS IS THE FIRST DANCE TUNE}

No one can tell all about

a woman's goodness. Days ago

my heart began to blossom out.

She frees me from the cares I know

when, dressed in all her finery,

she walks along in front of me.

No angel is more fair than she.

By storm a woman seized my heart and I must always be her knight. Her form is lovely, every part; her greeting fills me with delight. All one could wish in her I find; she leaves the others far behind or I'm no judge of womankind.

You have shown more friendliness to me than ever I deserve You alone, I now confess, are she whom I shall ever serve. I'm always happy on the day I see you, more than I can say. My heart is joyful then and gay.

All the cheer that now is mine I owe to no one else but you. You are dear, without design, and I would serve you and be true. If you'll permit I'll show you how I'll give away my freedom now. I'll serve you faithfully. I vow. 
I journeyed on with spirits high and reasoned thus, "As long as I have found a messenger to go for me and let my lady know about my wishes and my vow, why, I can be lighthearted now and need not sorrow anymore and be much gayer than before.

And so I travelled unconcernedit wasn't long till I returned. Five weeks I visited about and in this time, as I found out, my aunt had kept her word to me, had made the trip and gone to see my lady and was back again. I soon received a message then.

It pleased me much, without delay I rode to learn what she would say. My aunt was kind to me and good, receiving me as all friends should. "I did what you insisted on," she said, "but wish I hadn't gone. For, though I did what I could do, I've been no help at all to you.

"Now just sit down beside me here; I'll tell you very soon, my dear, every single thing we said so you can ncver be misled, what she to me and I to her. I was a faithful messenger and told her that you loved her best, more than yourself and all the rest.

"I said much more; before I closed I read the song which you composed. Then spoke your charming lady fair, 'It really is a pretty air, but one he might as well have kept; his service I cannot accept and want to hear no more of this. The topic we shall now dismiss. 
" 'Your nephew may be a worthy man; I'll grant him this and all I can.

I know him; at an early age he came and lived here as a page, and to his credit I can tell he served me loyally and well. But I insist he keep his peace. Requests like that will have to cease.'

" 'But, lady, they should not provoke your anger,' thus I quickly spoke, 'for young men often want and love an object they're not worthy of. They show their honor by their goal: the high desire, the lofty soul, and say a knight should prove his worth by wooing one of noble birth.'

" 'That he excels I'll take your word (although it's more than I have heard) in every virtue, every skill, yet for a woman it must still prevent a close relationship to see his most unsightly lip. You must forgive my saying so: it isn't pretty, as you know.'

"She wouldn't listen anymore. I counsel you as once before, let her wishes be your guide; since she has such exalted pride let her remain of service free however dear your honor be. Forget about her and display a lofty soul another way."

"I cannot follow your advice, dear aunt, for I would sacrifice such fervent hopes that she'll be kind; no words will ever change my mind. This counsel you should never give to me; I'll serve her while I live and only bitter death shall part me from the one who holds my heart." 
"Well I'll not help, make no mistake."

"No, auntie dear, for Heaven's sake you mustn't give me up this way.

Now listen to what I've got to say:

I'll have a doctor operate

upon my mouth. I shall not wait

and do not fear the consequence

since it's the cause of such offense."

"This I beg you not to do;

why it could be the death of you!

Live as God wanted you to live

and take whatever He may give

as being best for you and right;

this is the spirit of a knight.

To want what God does not ordain

reveals a spirit much too vain."

"God bless you, aunt, but I'm afraid that my decision has been made.

Be sure, no matter how things go, I'll not neglect to let you know.

I'll send you quickly any news and only ask that you will lose no time in giving it to her, yourself, or by a messenger."

87 "I'll do it, nephew, this I swear, but how I wish that you'd forbear and not go on with this you've planned." I rode away to Steierland and into Graz, a city blessed by many doctors; one was best. I went to see him and inquired if he would do what I desired.

He spoke, "Next spring come back again, sometime in May, I'll cut you then but not before. Return to me and on my honor you will see I'll make your mouth to such a fit that you'll be really pleased with it. I'm quite a master at this art and, what is more, I'm pretty smart." 
I spent the winter visiting the ladies all around. When spring and brighter days were coming on and winter's ice and snow were gone and birds were singing on every bough, I thought, "I must be going now to Graz and to the doctor's knife. May God in mercy spare my life!"

In Heavens's care I left that day. I soon encountered on the way my lady's page, a youth I knew, who saw and recognized me too. He said, "Hello," and asked where I was travelling, then asked me why. "I'll tell you all about it friend; it's rather strange what I intend.

"You see how well I am and strong, yet I'll be sick enough ere long and badly wounded in the head." The fellow crossed himself and said, "But, sir, what for, this thing is queer." I spoke, "My friend, see here, and here. It looks like three lips, when they're done with cutting, I'll be missing one."

"God help you if it's true," he spoke, "I quite agree, and do not joke, it's most surprising, every bit. My lady hasn't heard of it, I fancy, and I'll let her know. You must be mad in acting so, to take such chances with no need; why it could cost your life, indeed."

He rode his way and I rode mine, to get to Graz was my design. I sought and found the doctor there, at once he took me in his care. ' $T$ was Monday morning, not yet late, when he began to operate.

He wished me bound but I would not. He said, "You know, this hurts a lot. 
"And if you move by just a hair you'll come to harm, so best take care." I spoke, "You needn't be concerned for I came freely when I learned that you could fix this mouth for me. No matter what the pain may be no one will ever see me flinch, not by a fraction of an inch."

My fear was not so great at that. Before him on a bench I sat. He took the blade and with a slash he cut into my face a gash. Down to the teeth his razor went, which I endured without lament and, with the surgery complete, had yet to tremble on my seat.

Ios But now I think enough's been said of how my mouth was cut and bled to suit my lady. Now I'll tell you all about what then befell. My stay at Graz was long extendeduntil my face was fully mended. Then on my way I quickly rode until I came to my aunt's abode.

I06 While she was still far off she spied my mouth. Now hark to what she cried, "No one will e'er again decline you for your mouth. It looks just fine. I'm really very pleased about the way your suit is turning out. The tale already has been told to me of how you were so bold.

"The story will not go to waste. I wrote the whole thing up in haste and soon shall send it to the place where you so bravely seek for grace; I mean your charming lady fair. I'll tell her what you did and swear on all my hope of Heaven's bliss that she's responsible for this." 
"May God send rich rewards to you, my messenger so sweet and true!

Oh aunt, you make me feel so good and I'd repay you if I could

but you have done so much, I know, I'll never pay the debt I owe.

I always knew I could rely

on you. But here's a song that I

"composed. Please write it carefully

and send it on to her from me.

In Graz while I so long was ill

I worked on it with all my skill.

Her praises turn my grief aside,

her praises fill my heart with pride,

her praises always make me gay,

but hear! The song has this to say:"

\section{THIS IS THE SECOND DANCE TUNE}

What shall I sing

about the night? I have no pleasure then.

The day must bring

fulfillment of my hopes-I see again.

Besides, its light

recalls the sight

of her I love, and is a true delight.

Well may he praise

the night who lies with love and shares its bliss, but it dismays

my lonely heart. I hate the night for this

and praise the day

for then I may

see her who drives my sorrows all away.

I celebrate

the day when first I saw my lady fair.

Since then I wait

for dawn with more and more of grief and care.

The night's to blame

that I became

so sad. But, Day, most blessed be thy name. 
I am possessed

at night by grief and hosts of anxious fears.

They're put to rest

at once as soon as day's first light appears.

For then I know

that I must go

and watch in secret her whom I love so.

Oh gladly would

I praise the night if it were not in vain, or if I could

lie beside the one who brings me pain.

If it might be,

what ecstasy!

Alas, she will not grant this joy to me.

I I I

"The song and letter I shall send

and to the words already penned

shall add the other things I've learned.

I'll tell her that you've just returned

and see it's clearly understood

that now your mouth looks just as good

as any other man's. Thereby

I'll not be telling her a lie.

I I 2

"The answer which I get from her

I'll send to you, if you prefer,

so you will know what's on her mind."

"Do, aunt, your messenger will find

me at the castle on the Mur."

With this I left her; feeling sure

and happy with this suit of mine,

I took the road to Liechtenstein.

My aunt, as soon as I had gone, took song and note and sent them on directly to the castle where her servant found my lady fair.

He didn't have to wait for long; as soon as she had read the song and note, she penned a letter such that, when I got it, pleased me much. 
The letter reached my aunt and she dispatched it quickly on to me. The servant didn't spare his horse; I've her to thank for this, of course. The letter made my heart so light and filled my soul with proud delight. No message ever brought such cheer to me. But only listen here:

"My best wishes and my devotion I gladly extend to you and inform you that next Monday I shall leave the castle where I am still residing and shall journey to the castle which you well know, and shall stay overnight at the market which lies near you. Now I beg that you will not fail to visit me there. Then I shall respond to everything which you spoke of in your message. If your nephew wishes to come too I shall be glad to see him-to find out how his mouth looks and for no other reason."

\section{The Adventure of How Sir Ulrich First Spoke With His Lady}

I started when the contents were made known to me and rode to her, and I was very happy then in thoughts of seeing her again. I came with spirits high, but oh, the lovely one was guarded so that evening that I never had a glimpse of her, which made me sad.

16 I didn't sleep at all that night and with the early morning light got up and went to where I knew were staying all her retinue.

Knights and many a page were there. When greeted with a friendly air at once they answered with respect and manners cordial and correct.

How quickly did the hour pass! My lady's chaplain sang a mass which filled my heart with joy for I could watch the lady on the sly. I'd gone with fear to where she met her guests and I was trembling yet. She'd bowed to me when she had heard my greeting, but had said no word. 
The mass was over. Speedily they told the other men and me to leave the chamber. It was plain they wouldn't let a man remain. My lady ate and rode away. I went to see what aunt would say. She laughed and tenderly began, "You surely are a lucky man.

"My lady says that she'll permit you now to come and talk a bit and say whatever's on your mind; she's rather favorably inclined. You'll follow when she starts to ride and chance to come up by her side; then you may tell what's on your heart, but tell it quickly and depart."

This made me happy and, of course, I very soon was on my horse. When I beheld her up ahead my heart spoke out with joy and said, "Now there! Now you at last will speak with her and tell her what you seek. She rides before you all alone. Go up and make your wishes known!"

Without delay I hurried there, but when the lady was aware of me she turned away her face, which made me feel quite out of place and I became so shy therefrom that tongue and lips at once were dumb. My head sank down irresolute and I was silent as a mute.

There rode up then another knight and I dropped back, still dumb with fright. I rode behind subdued by fear. This time my heart was more severe, "You coward, why should you retreat before a lady who's so sweet, who wouldn't do you any harm?

Why lose your voice in such alarm?" 
Again I rode up to her side, quite pale with fear I could not hide, my dread of speaking plagued me so. My heart then gave me many a blow and leaped within me ever higher, to talk right out was its desire.

It spoke, "Now speak, now speak, now speak! She's all alone, don't be so weak!"

I opened my mouth ten times at least to talk. Each time my fear increased. My tongue was still so tightly bound I couldn't utter a word or sound. I'll not discuss this any more; I left her as I'd done before and didn't say a single word. Five times that day the same occurred.

There came at last the journey's end.

The lady stopped where she would spend the night; they'd saved for her a room. The parting filled my heart with gloom. I took the stirrup which one needs to lift the ladies from their steeds and helped them down with this device. (Some of them were really nice.)

She waited there, the kind and good, upon her steed. Around her stood many a knight and page. With these my lady liked to joke and tease.

I took the stirrup to where she sat; she spoke, "You've not the strength for that. You cannot lift me down, for you are frail and weak, and tired too."

I34 Loud was the laughter of the men. She stepped upon the stirrup then and from the saddle down she slipped, but, as I lowered her, she gripped my hair and, so that none could see, she quickly tore a lock from me. "That's what you get for being shy! What I've been told of you's a lie." 
She joined her friends when this was said.

I stayed behind with lowered head and thought, "What happened to me indeed!

I must in honesty concede

no one was ever such a dunce;

she must have thought that more than once!

She'll surely never let me serve

her now. I got what I deserve."

I36 I lingered on in dark despair.

A knight said I should go from there:

't was time the ladies got some rest.

I rode downtown where I could best

secure myself a lodging place.

I prayed to God that by His grace

He'd take this life which was so sad

and all the other things I had.

Why should I tell the night's sad tale, of each lament and every wail

until the coming of the day?

Sometimes I sat, sometimes I lay, sometimes got up and walked about, now in the room and now without.

I often wrung my hands with woe;

a cousin came and found me so.

'T was early yet. Without ado he spoke to me, "What's wrong with you?" I said, "I've got a frightful ache, my heart feels like it soon would break, the pain increases more and more, and that's what I'm so troubled for. I cannot lie nor stand nor sit but walking helps a little bit."

I44 "They've got a doctor here," he said. "Bring him to me." Away he sped to find out where the man might be. I had them get a horse for me, a servant too. We then took flight from the hostel where I'd spent the night and raced like a crazy man might run to where I'd left the lovely one. 
As I approached at breakneck speed I saw her mounted on her steed and riding toward me down the street. 'T was just like I had hoped we'd meet. In handsome dress along she rode with hooded cape as is the mode. When she looked up, she made a bow. I was no longer silent now.

I spoke, "My lady, let me find for love of God that you are kind to me, and through the nobleness that God permits you to possess. Be kind, O lady, full of grace, may I see favor in your face. In you do all my joys unite; you are my feast of pure delight.

"You must believe what now you hear, that I have served you every year since that sweet hour I'll ne'er forget, so long ago when first we met. I'm in your service as your man, I'll serve you just the best I can and never anyone but you.

You can be sure that I'll be true.

"For you, my lady kind and good, I'd risk my life whene' $\mathrm{cr}$ I could in any knightly deed or game and always do it in your name. Whatever way a knight can serve I'll serve you well, as you deserve. I should, I will, indeed I must remain your knight till I am dust."

"Silence, you're nothing but a youth, for these high things still too uncouth. You'll stop such childish chattering if my regard is worth a thing and ride away from me at once. You still are something of a dunce! This talk can bring you grief and care and will not get you anywhere." 
"It's true, dear lady, I am still too simple, for I lack the skill to speak to you the way I ought or tell my feelings as I sought. In some respects I'm much more wise and win from other knights the prize. I'll serve you thus and shall not fail; for things like this I'm not too frail."

"Just leave me now is my advice, I shouldn't have to tell you twice. I don't like talking secretly; you ought to know they're watching me. If any knight or lady guessed what you have said I'd be distressed. You must be still at once and go! You're very troublesome, you know."

There wasn't any more to say so I took leave and rode away, quite pleased. As far as I could tell, my suit was going rather well. At least I'd told my ladylove in part what I'd been thinking of. My spirits mounted more and more; I'd never felt such joy before.

I57 At once I joined a knightly band. Where'er they gathered in the land there I was always seen, and none could fail to know that I was one. That summer I had so much luck that one time in a joust I struck a worthy knight clear off his steed. (She thanked me later for this deed.)

I 58 Of my achievements I'd reveal much more but think that some might feel I praised myself a bit too much; so I'll be still for fear of such. All summer I was filled with pride, and as a lady's knight should ride I rode. If I had some success ' $t$ was quite deserved, I must confess. 
With happy heart I journeyed then to see my gracious aunt again, just as a man in love would do. I got a kindly welcome too. I said, "I pray that God will grant rewards, my messenger and aunt, to you whose friendship cannot fade. My joy depends upon your aid."

"If I can help with your request, nephew, I'll gladly do my best. Once more to meet your wish I'll send a message to your lady friend and tell her, if this be your will, at Friesach no one showed more skill or bravery than you. And I am sure that this will be no lie."

"Dear aunt, you always do me good, I'll always thank you, as I should. Please send along this poem here; I do not have the slightest fear that she'll not like the words or air for she's so kindly and so fair and ever generous with praises. The song describes her with these phrases:"

\section{THE FOURTH DANCE TUNE}

Little birds in forest bowers sing as one their sweetest lay. On the meadow pretty flowers bloom against the light of May. So now blooms my self-esteen in the thought of her devotion which enriches my emotion as a beggar by a dream. 
High the hopes I hold and nourish in the presence of her charms that my fortune still may flourish till I hold her in my arms. Such desire is all my joy. Now may God in fullest measure grant that these, the hopes I treasure, she I love will not destroy.

May the gentle one I cherish free of fault or broken vow never cause this dream to perish which is all I have for now. May my pleasure never wane, may I not in tears awaken, may I laugh, with courage taken from the solace I shall gain.

Pleasant thoughts and fond desires, thesc are all the joys I sing. But my love for her requires little more if I may bring both into her company that she willingly may tender something of her charm and splendor and be ever kind to me.

Blessed May, your gentle weather warms the whole world with its kiss. You and all the world together bring me not a mite of bliss. For what pleasure could you give were the lovely one not near me? She alone has power to cheer me, from her solace I must live.

I left my aunt ere very long. She sent the letter and the song to where the charming lady stayed and answered thus my plea for aid. When the messenger appeared the one whom all so much revered said, "You are welcome. Tell me how is your dear lady doing now?" 
He then replied, "Her health is good and she conveys, as well she should, her great devotion here to you, but she has sent a letter too.

Please read it now and let me go and God will bless you, this I know. My lady told me to bestir myself-the letter came from her."

She read the letter, laid it by, and wrote another in reply. She gave it to the page: "Now tell your mistress I am glad she's well, and give her my regards, and let her have this message. Don't forget to tell her frankly that I doubt the contents of her note throughout."

The messenger quite soon returned and sought his mistress. When she learned he had a note she sent him on to Leibnitz; that's where I had gonc to take part in a tournament. Three hundred knights at this event strove for honor and for gain; to some came wealth, to others pain.

I warmly greeted him who brought the message and at once we sought a private place. He gave me then the note-so kind my aunt has been! I thought the letter would impart that which would please my longing heart; it took away my joy instead.

Now listen here to what it said:

"This nephew the loftiest praise you give, perhaps since he's a relative.

But other folks never praised him at all, which makes your praise seem rather small. When you're so lavish in your praises I censure you for empty phrases." 
I never in my life felt worse than when he read to me this verse; the message covered me with shame. I thought, "I'll have to win the fame that knightly deeds alone can bring or I shall soon lose everything: the life, the goods for which I've striven, and all besides that God has given."

I journeyed far to foreign ground wherever knightly games were found, be they in earnest or in fun, I could be seen at any one. My body and my wealth I spent quite willingly, ' $t$ was my intent. To show my lady great respect my steed and I were richly decked.

But now the winter's cold came on, the forest greenery was gone and silent was the cheerful chant of birds. I went to see my aunt and told her of my grief and pain. She spoke, "I need to make it plain that you can't send my page once more to take your message as before.

"She has forbidden me, in truth, to send her e'er again this youth. She fears the evil talk of some and won't permit that he should come. I'd be so foolish were I still to act contrary to her will and send him there, and quite in vain; for this I'd have to be insane."

"Auntie, since your messenger can ne'er again be sent to her I'll have to find another who will go. She shan't forbid me to. For whether joy or pain prevail my loyalty will never fail.

My heart has thought the whole thing out; of this there'll never be a doubt. 
"Aunt, for what you've done for me I'm just as thankful as can be.

I'll always feel a debt to you; you may be sure that this is true." I said goodbye and went along and, while I rode, composed a song, quite as my loving heart advised, about the lady whom I prized.

\section{THE FIFTH DANCE TUNE}

Summer now is gone away, the birds will sing no more this year.

I am left forlorn today: my heart's sad song alone I hear.

Winter and another grief together give my heart much pain:

the two conspire against my heart's relief.

Summer's joys do well prepare the lover's spirit (this I know) for the service of the fairOh blest be summer's lovely glow! Hateful winter I despise, but summer's bliss I love, for then can one serve well the lady he does prize.

What does winter mean to me, what good are long, cold winter nights?

Indifferent to this is she who could grant me such delights. Would that my distress might end in the same sweet repose as his who lies within the arms of his sweet friend.

Sorrow follows love fulfilled:

so should rejoicing follow pain.

Since my sorrow is not stilled, therefore my hopes all green remain. Lady, you could change my state from sadness into greatest joy.

While others dance, my woe does not abate. 
Lady dear, oh lady mine, why do you hate and wound me so? Service is my sole design, as you (and God as well) do know. Never have I gone astray or let my heart to others turn since narrow path I knew from crooked way.

I rode that winter up and down to visit ladies near the town by which she dwelt. I was, I own, more constant than a precious stone. My faithful heart considered much how I might find a servant such that I could send her, just to tell how I desired to serve her well.

Unhappily the proper kind of messenger I could not find. I searched the country end to end and found not one whom I could send. This caused my longing heart to grieve with sorrow nothing could relieve; my life was nearly empty of all joy because of thwarted love.

Delight was almost gone, but then the merry summer came again and brought its charm, as is its way, and many a beautiful summer day. I thought, "I'll serve my lady dcar most gladly through another year and better than I have before, and so perhaps I'll please her more."

No time was wasted, I confess, till I had steeds and battle dress. I'd soon forsaken my abode, to Carinthia and Krain I rode and down to Istria. ' $T$ was there that Meinhart von Gorze bade them prepare Triest for many a knightly game, which served to further spread his fame. 
Before the knightly sport was done a name for many a man was won who so excelled in knightly arts that he subdued the ladies' hearts. Count Meinhart jousted very well, as oft before and since befell. I know at least a hundred spears were broken there by cavaliers.

I used up fifteen spears with skill and bravery. I stayed until the games were over. Then I went to Brixen to a tournament. My dress was courtly as can be, my only thought was chivalry. I wished to serve my lady sweet with many a bold and daring feat.

The Adventure of How Sir Ulrich Lost His Finger

When I arrived there many a knight received me warmly, as was right; their courtly manners were the best. They knew how one receives a guest and greeted me with such display that I felt welcome right away, for one could tell they wished to please. I thanked them all and felt at ease.

The sides were chosen for the game and with the morning light we came onto the Merre, a nearby field; we hurried there with spear and shield. It soon began; so I was told, a hundred valiant knights and bold strove with each other up and down the field that day and won renown. 
At last it was empty of steeds and men but only hear what happened then.

Sir Ulschalk von Bozen challenged me to show my lady constancy

and break with him a spear or two;

this I was very glad to do.

Before another word was said

each tied his helmet on his head.

343

With heavy lances poised in air we charged upon each other there;

the joust was finely executed.

Sir Ulschalk, who is well reputed, struck my hand while passing by and knocked a finger off, so I had to remove my helmet then to show I couldn't joust again.

We rode at once to town to find a doctor who would come and bind my hand. Soon one was at my side. He saw the wound was deep and wide but thought the hand could be restored (the finger hung by a single cord) He said, "If treated right, I feel that hand and finger both will heal."

These tidings filled my heart with cheer. I told the doctor, "Listen here, if what you say to me is true I'll willingly present to you more wealth than you will ever need, enough to make you glad indeed. Just save the finger and you'll get a thousand pounds to pay my debt."

At once the doctor took command. $\mathrm{He}$ carefully tied up my hand and in the bandages it lay right up to the seventh day. But, when the doctor then unbound the hand to see the wound, he found that it was swollen and so black that even he was taken aback. 
My heart was filled with deep dismay. A worthy doctor, I'd heard say, was near, at Bozen, so I spurred my horse and left for I had heard, if I should come before too late, the doctor's learning was so great that he would surely save my finger. I rode to him and did not linger.

I entered Bozen then in haste. The doctor also did not waste much time but came to do my will; I'd sent him word that I was ill. He saw my wound, examined it, and said, "You need not fret a bit. It won't take long for me to cure your hand and finger, I am sure."

I sought a messenger whom I could send. I'll tell you, it's no lie, there simply wasn't one to find, which quite disturbed my peace of mind. I couldn't even let her know that all for her I suffered so. This worried me; the truth to tell, I didn't like it very well.

My thoughts were troubled, but in vain; my finger also caused me pain. The wound was often bound for me which made it bleed quite heavily. Twice daily I endured this curse but still my spirit pained me worse. To find no person to employ as messenger killed every joy.

A messenger at any cost I had to have or all was lost; with great concern my heart was stirred. But listen now to what occurred: Not far away there lived a youth, my friend, and one who spoke the truth. He came to see me and express his sympathy in my distress. 
"God knows I wouldn't say to you," he spoke, "a thing that wasn't true; I pledge my hope of Heaven's bliss that I am worried over this. If I could have my way, I know I'd gladly take on me your woe and every pain I'd gladly bear. I'd do it, on my word I swear."

I spoke, "I do not doubt you would and I believe you, as I should; you've been a friend. My heart will break with sorrow more than it can take in thinking of a lady sweet whom I have served with many a feat. Could I but find a messenger to say I got this wound for her!"

"Sir Friend, hear this I have to say: it's not two weeks ago today since I have seen your lady fair. If I may do so, I declare that I have known her just the same although you never spoke her name. I know her well enough to state that you're no object of her hate."

I spoke, "It's well that you're my friend. That I've done nothing to offend you, I am very glad to hear, especially since you are dear to her. That you can tell her what you wish, this cheers my heart a lot. For you, my friend, will have to be the messenger to her from me."

"I'll be the messenger you need and carry any news indeed which you may want her to receive. That I'll do this you must believe. I'll quickly tell her what you will and bring the answer, good or ill, to you at once. I'll not suppress a thing, though it be 'No' or 'Yes.'" 
"Friend, I pray that God requite your help to me in this sad plight. Now tell the lady from us both and swear to her a solemn oath that I have always loved her best, more than myself and all the rest, and also more than any thing. I serve her with no wavering.

"You ought to let the lady know that only several days ago I lost a finger which was born to serve her. This I've often sworn. ' $T$ was in a joust. I'll not complain but gladly suffer loss or gain for her, and never seek relief from either happiness or grief.

"Now ask the lady if she'll let me be her knight, and don't forget to beg her by the charm in which God in his kindness made her rich that she will send me cheerful news to end the sorrow that subdues my heart. You ought to talk about these things with her. Leave nothing out."

He said goodbye and then he rode until he came to her abode.

When he arrived my lady fair at once bade him be welcome there. She said, "Friend, you must tell me how your mistress is; what's she doing now? Be sure you tell me just the truth and only that, well-mannered youth."

The page's answer was refined:

"Gracious lady fair and kind, since it's the truth that you prefer, well then, I haven't come from her. A knight has sent me here, I own, whose sore distress I long have known. He sends you, lady good and pure, a loyalty which will endure. 
"He bade me tell you his distress and hopes you'll grant his suit success. Quite recently he was so true that he was wounded serving you. I ought to tell you what it cost: a finger from his hand was lost. He used it just to serve you right and lost it as a gallant knight.

"He's chosen you, is what he swore, to be his lady evermore, and with such constant loyalty that he will ne'er be sorrow free unless you're favorably inclined to him, my lady good and kind. You're more than all the world to him, than riches, ladies, life and limb."

"Tell me who has been so bold and sent the message you have told. God knows that I don't care for it. What man could have so little wit to send you here with such a claim? Speak up! I'd like to learn his name. And you should know that you don't please me when you bring me words like these."

"Lady, the name I'll gladly tell for he has always kept it well. He's called The Knight of Liechtenstein, Sir Ulrich; he's a friend of mine whom you can trust, and I am sure that his devotion will endure; he's never won so great a prize as you, dear lady fair and wise.

"My lady sweet, if you would yield and let him be a while concealed alone with you 't would be such bliss. He'd not exchange the Grail for this which valiant Parzifal did gain with knightly deeds and bitter pain. His heaven and his paradise is you, so lovely and so nice." 
"Tell him from me, you courtly boy, I'll not permit him to destroy my peace this way. He must console himself and find another goal more suitable to him, for I shall certainly grow old and die and all the while learn nothing of that which is known as secret love.

"Here's the message you're to bring (take care and don't forget a thing): he'll quit the service he's begun or lose the honor he has won. If he believes my mind will change he'll quickly find that I'll arrange that he shall suffer such disgrace he'll never want to show his face."

"I'll tell him, lady, as I should, though it will surely do no good. His mind is fixed, dear lady, so that he'll not let his service go. He can't be stopped by pain or need or even fear of death, indeed, and will not leave your service now no matter what may come, I vow."

He said goodbye and then returned to where I waited, quite concerned. I saw the messenger come near and what I said you now shall hear, "Be welcomed by both God and me, you page, so skilled in courtesy.

Tell me, were you successful there? How did you leave my lady fair?"

"She is healthy, she is gay. She instructed me to say. you'll leave her service without ado if life and honor are dear to you. Should you not heed the words she sends, through other means she'll gain her ends and bring such mischief on your head that you'll be overcome with dread." 
"My friend, no matter what may come, no matter what I suffer from, my service shall continue on until my life itsclf is gone.

Though things go well, though things go ill, ' $t$ is she I'll serve, such is my will, and while $I$ live no joy shall stir my heart but that which comes from her."

I spent the summer in Steierland and often tied my helmet band. To earn my lady's love I meant to joust with knights where'er I went, and very eagerly I fought.

With constant faithfulness I sought to serve her as a suitor should who hopes that his reward is good.

The summer and every summer joy wcre gone. Once more I urged the boy (I mean the messenger) that he would see the lady fair for me. He spoke, "To her I'll gladly ride and tell whatever you confide, of how you sorrow and you pine, and speak as if the thoughts were mine."

I told to him without delay just what I wanted him to say and sent to her a song again. With joy he parted from me then. When he had reached her dwelling place she welcomed him with friendly grace. "Pardon," he said, "if I intrude, I hope you're in a better mood

"than you were in when last we met." The lady answered with regret, "What have I done to cause offense? Now tell me that without pretense. You know, you always have been dear to me. You can be happy here, and though I may not always please you never need feel ill at ease." 
"God pay you from his boundless store!

I come as messenger once more to bring a message from a knight who seeks for favor in your sight and offers, lady dear, to you a greeting and his service too, esteem and loyalty and love, and all a man is master of."

"You're both quite good at flattering but I shall tell you this one thing: you said (it really makes me mad), in serving me Sir Ulrich had lost a finger. I deny the boast and think it just a lie. I'm told, he has the finger still. I wish you wouldn't do his will."

"Lady, he has it, I'll admit, and yet, so badly bent is it, it cannot do him any good and doesn't help him as it should for he can't move it very well. But one thing I'll be glad to tell: it firmly holds, so it appears, in serving you some heavy spears."

'I'm glad his finger's on his hand but lies as this I cannot stand. He has it still, and you have told a lie in part; that's why I scold. Now I shall talk with you no more, so go back where you were before and, courtly boy, you'd better sec you bring no messages to me."

My messenger departed then and soon was back with me again. When I caught sight of him I cried, "Dear messenger, come right inside and tell what happened right away. What did the lovely lady say? If I should hear good news at last my heart will never be downcast." 
"She didn't send a word to you but she told me a thing or two. I'm not to be your messenger; she said, it greatly vexes her and gives her cause to be irate that I should come to her and state, you lost a finger and were maimed for her. It was a lie, she claimed.

"She heard the finger was all right and she believes the wound was slight; what I have told of you is lies and I've deceived her, she implies. She's peeved at me and quite upset but glad you have the finger yet. She wouldn't have the wound be bad, it's just the lie that makes her mad."

I thought, "Because my lady dear is vexed about this finger here, that I still have it, 't would be best (since it's less useful than the rest) to cut it off and have him leave the thing with her. For she'll believe it's really lost when she looks at it then. It goes, and that is that."

I left him and at once began to seek a certain honest man, von Hasendorf, so he was named, Sir Ulrich, who was widely famed for courage and a level head.

He wished to serve me, so he said. I bade him show his loyalty and cut a finger off for me.

"I'll do your will, you may depend on me for truly I'm your friend, and vassal too. I wish to serve you always, as you well deserve." I took his knife and unafraid across my finger set the blade. I spoke, "Now strike, good man, and well!" He struck, and from my hand it fell. 
While still the blood was running strong my well-bred courier came along and quickly whispered in my ear, "What now? What are you doing here? Did you cut off your finger? Oh, for this my heart condemns me so because of what I've seen and heard and that I told you a single word."

“My friend, you needn't start a row, just take to her my finger now and tell her that she can depend on this: I'll serve her to the end with loyalty that's never swayed. And if this service is not paidthat, of all women everywhere, I've chosen her-it won't be fair."

"It grieves me so to see you bleed but now that you have done the deed you should compose a note of praise with many a pretty word and phrase to send, whatever else you do. Of course I'll take the finger too. I'm pleased to help in your distress; God grant my trip completc success."

"I'll gladly do it since I can." At once I started and began a very nice and clever lay. With it my finger rode away to where the lady dear was seen. In velvet, soft and grassy green, they wound the verses speedily. I had a goldsmith make for me

without delay two bands of gold. In these the lay was put. To hold it firm was made a little clasp in shape like tiny hands that grasp each other-all was formed with care. The finger now was put in there. When everything would satisfy the messenger then said goodbye. 
I spoke, "God care for you, I pray, while there as well as on the way!" With this, I watched the page depart and stayed behind with heavy heart. The verse was hidden in his coat when he arrived, so none took note. He went to her with fear and dread; the lady looked at him and said,

"I welcome you again, young squire, although you really stirred my ire. If you have something new to tell I'll let you speak. What now befell?" "Dear lady," quickly spoke the boy, "my lord has chosen to employ me once again, and to entrust me with the finger we discussed."

He showed her then the little book which the lovely lady took, and you'll believe her great surprise when the finger met her eyes. "Alas," she said, "what have you brought? I'm sure I never would have thought that any person sound of mind could be so foolish or so blind."

She read my verses to the end and spoke at once, "My youthful friend, what can I tell you? I'll not hide my sorrow that the finger died but that's not fondness for the knight. I'm sad because you may be right in saying that it thus was slain because of me. This gives me pain."

"Lady, I'll tell you how it went. Not long ago when I was sent away from here he then received the news that you were very peeved at me for saying, lady grand, he'd lost a finger from his hand in knightly service, and that you were mad because it wasn't true. 
"He left me quickly when he heard the story. Lady, take my word that almost on the very spot he found a vassal whom he got to cut his finger off and maim him thus. Right after that I came and when I saw him bleeding still, I must confess, it made me ill."

"Go back and tell him my regret; he' $d$ serve the ladies better yet, were it not that his hand is shy a finger. Tell him too that I shall always keep the finger near, buricd in my dresser herc, that I shall see it every day, and that I mean just what I say.

"Tell him from me now, courtly youth: I'll keep the finger-not, in truth, bccause my heart at last is moved so that his prospects are improved by a single hair. Make sure he hears this: should he serve a thousand years, the service I would always scorn. By my constancy I've sworn."

With this the messenger returned. When he recounted all he'd learned I was pleased with the whole affair; that she had kept the finger there was enough to fill my heart with joy and so I said this to the boy, "I'm very glad to hear that she will keep the finger there for me.

"Whene'er she sees it, this is plain, she cannot possibly refrain from thinking that I serve her well. She has it and her mind will dwell on me. The prospect does me good. I'll serve her always as I should, on her my pleasures all depend, she is my May and winter's end. 
"My service must be God's command. Now let me tell you what I've planned. I'll take on woman's dress and name and thus disguised will strive for fame. Swcet God protect me and sustain! I'll travel with a knightly train up to Bohemia from the sea. A host of knights shall fight with me.

"This very winter I shall steal out of the land and shall conceal my goal from everyone but you. I'll travel as a pilgrim who to honor God is bound for Rome (no one will question this at home). I'll stop in Venice and shall stay in hiding till the first of May.

"I'll carefully remain unseen but deck myself out like a queen; it should be easy to acquire some lovely feminine attire which I'll put on-now hear this lastand when St. George's day is past, the morning afterwards, I'll ride (I pray that God is on my side)

"from the sea to Mestre, near by Venice. He who breaks a spear with me to serve, by tourneying, his lady fair will get a ring of gold and it will be quite nice. I'll give it to him with this advice, that he present it to his love, the one he's in the service of.

"Messenger, I'll make the trip so there will never be a slip and no one possibly can guess whose form is hid beneath the dress. For I'll be clad from head to toe in woman's garb where'er I go, fully concealed from people's eyes. They'll see me only in disguise. 
"If you would please me, messenger, then travel once again to her. Just tell her what I have in mind and ask if she will be so kind as to permit that I should fight throughout this journey as her knight. It's something she will not repent and I'll be glad of her assent."

He rode at once to tell her this and swore upon his hope of bliss my loyalty would never falter, that I was true and would not alter. He told my plan in full detail and said, "My lady, should you fail to let him serve and show your trust in him, it wouldn't seem quite just."

"Messenger," she spoke, "just let him have this message, don't forget. This trip, if I have understood you right, will surely do him good and he will win a rich reward in praise from many a lady and lord. Whether it helps with me or not, from others he will gain a lot."

468 The messenger was pleased and sure. $\mathrm{He}$ found me by the river Mur at Liechtenstein where I was then. ' $T$ was nice to have him there again. I spoke, "O courtly youth, now tell me if the lady's feeling well. For, if my darling's doing fine, then shall rejoice this heart of mine."

He spoke, "She's fair and happy too; she bade me bring this word to you about your journey. If you should go through with it ' $t$ will do you good and, whether it helps with her or not, from others you will gain a lot. She certainly supports your aim and says that you'll be rich in fame. 
The Adventure of How Sir Ulrich, Dressed as a Queen, Rode Tourneying Through the Lands

470

I listened to the news he had, and heart and body both were glad.

It was a joy for me to know

my undertaking pleased her so.

I didn't linger but began

at once to carry out my plan

and was quite happy, I admit,

that he also approved of it.

471

I soon was ready, I assure

you, to begin my knightly tour.

I started out as pilgrim dressed

and left the land. I thought it best

to take a staff and pouch at least, for looks (I got them from a priest);

one would have thought me bound for Rome.

I prayed God bring me safely home.

472 I got to Venice without delay and found a house in which to stay, right on the edge of town, a place where none would ever see my face who might have recognized me there. I was as cautious everywhere and all the winter long I hid. But let me tell you what I did:

I had some woman's clothing made to wear throughout the masquerade. They cut and sewed for me twelve skirts and thirty fancy lady's shirts.

I bought two braids for my disguise, the prettiest they could devise, and wound them with some pearls I got which didn't cost an awful lot. 
I bade the tailors then prepare three velvet cloaks for me to wear, all white. The saddles too on which the master labored, stitch by stitch, were silver white. As for a king was made the saddle covering, long and broad and gleaming white. The bridles all were rich and bright.

The tailors sewed for every squire (there were a dozen) white attire. A hundred spears were made for me and all as white as they could be. But I need not continue so, for all I wore was white as snow and everything the squires had on was just as white as any swan.

My shield was white, the helmet too. I had them make ere they were through a velvet cover for each steed as armor. These were white, indeed, as was the battle cape which I should wear for jousting by and by, the cloth of which was very fine. I was quite pleased to call it mine.

At last I had my horses sent to me (none knew just where they went) and got some servants, as I'd planned, each native to a foreign land. They carefully did not let slip a thing about my coming trip and I took heed that those who came to serve me never learned my name.

Soon we were all prepared to go; how pleased was I that this was so. I sent a letter on apace by messenger to every place where I had planned to stop awhile and urged upon him craft and guile that none might ever guess or hear my name. He said I needn't fear. 
"The noble Queen Venus, Goddess of Love, sends to all of the knights who reside in Lombardy, Friuli, Carinthia, Styria, Austria, and Bohemia her good wishes and her greeting and announces that, because of her love, she will journey to them and will teach them with what sort of things they should earn or win the love of noble ladies. She announces to them that the day after Saint George's Day she will rise from the sea at Mestre and will travel as far as Bohemia on this mission. Whichever knight comes against her and breaks a spear in two against her she will reward with a golden ring which he is to send to the lady whom he loves most. The ring has the power to make the lady to whom it is sent all the more beautiful and to cause her to love faithfully him who sent it to her. If my Lady Venus unhorses a knight, he is to bow toward the four ends of the world in honor of a woman. If she however, is unhorsed by a knight, he is to have all of the horses which she brings with her. She will ride the first day to Treviso, the next day to the Piave River, the third day to Sacile, the fourth day to St. Odorico, the fifth day to Gemona, the sixth day to Chiusa Pass, the seventh day to Tarvisio, the eighth day to Villach. She will spend the ninth day there quietly. The tenth day to Feldkirchen, the eleventh day to St. Veith, the twelfth day to Friesach, the thirteenth day to Scheifling, the fourteenth day to Judenburg, the fifteenth day to Knittelfeld, the sixteenth day to Leoben, the seventcenth day to Kapfenberg, the eighteenth day to Mürzzuschlag, the nineteenth day to Gloggnitz. She will remain there for the twentieth day. On the twenty-first day she will be in Neunkirchen, on the twenty-second day she will be at Neustadt, on the twenty-third day she will be at Traiskirchen, on the twentyfourth day she will be at Vienna where she will remain over the twenty-fifth day, on the twenty-sixth day she will be at Korneuburg, on the twentyseventh day she will be at Mistelbach, on the twenty-eighth day she will be at Feldsberg, on the twenty-ninth day she will be beyond the Thaya River in Bohemia; there her journey will end. On the journey she will let no one see either her face or her hands; she will also not say a word to anyone. She decrees that on the eighth day after the end of her journey there shall be a tournament at Korneuburg. Whichever knight hears of her journey and does not come against her she places under the ban of love and of all good women. She has listed all of her stopping places that each knight may know where or when he may come against her, so that it may be most convenient for him." 

or read to make my journey known it made a lot of happy men. In German lands the custom then was such that none had honored names who did not strive in knightly games or win through ladies joy and pride. I wish this custom had not died.

Each knight prepared with joyful heart to welcome me. 'T was time to start; now that Saint Georges's Day was past my journey could begin at last. ' $T$ was early when I started out but soon the people thronged about and many walked along behind. Great feats of valor filled my mind.

482 My marshal and my cook, with three to help them, led the company; they cared for food and bed and more. Behind them came a man who bore a banner, white as any swan; two rode beside him, playing on their horns. They made so loud a sound that Mestre echoed round and round.

My three pack horses then were led along, a groom at each one's headgood lads and fit for any deeds. There followed them three battle steeds, each with its groom that it not lack for care, and on each horse's back was fixed a saddle, silver white.

The saddler knew his trade all right.

484 Beside a battle steed was born my shield of white. I would have sworn a finer one I'd never seen nor one as suited for a queen. My helmet too was carried there; none shone like this one anywhere. On top of it a crown was wrought which was quite splendid, so I thought. 
A flutist was the next to come who beat with skill upon a drum. Four squires were riding after him in uniforms of modish trim and each had brought three spears along, well-made and large, which with a thong were bound together. One could praise these bearers for their courtly ways.

Two maidens rode behind the squires and every bit of their attires was gleaming white from head to toe. They both looked very pretty so. A fiddler rode behind each maid; my heart was happy when they played, and when the two would fiddle high a marching tune most pleased was I.

487 I followed after all the rest, in shining raiment richly dressed. My cloak was velvet and was white as was my hat, but this was bright with many pearls on every side. My loving heart was filled with pride that I should serve my lady now with knightly deeds and keep my vow.

The braids I had were thick and brown and were so long that they hung down below my sash, just like a girl's.

They too were richly decked with pearls and in a most artistic way.

My heart has seldom been so gay.

Nobody ever owned before

a fairer skirt than that I wore.

I had a white and glossy shirt which was as long as was the skirt with woman's sleeves of quality that made me proud as I could be. My gloves were silk and finely made. Attired like this and unafraid I left the sea as I had vowed, and soon collected quite a crowd. 
They'd only come to look at us.

I had a servant question thus, "Are there no jousters hereabout?" They answered, "Lady, yes. No doubt there are at least a thousand here who would most gladly break a spear with you but jousting in this state is outlawed by the magistrate.

"The Lord of Treviso has decreed that anyone who doesn't heed and jousts with you upon these grounds must pay at least five thousand pounds. We're greatly troubled by this ban. He's such a grim, forbidding man and never stops to play awhile. One almost never sees him smile."

I journeyed forth without delay, dressed in a woman's fine array, on to Treviso merrily.

A famous count rode up to me with fifty well-clad mounted men. We quickly recognized him then and he was greeted as he came. Count Meinhart von Gorze was his name.

The worthy noble was concerned when he found out what we had learned: that we could do no jousting there. He said, "How's that? Why, who would care?" "The magistrate," a squire replied. "It's wrong that this should be denied," spoke he, "and knightly games be banned. Can't we have pleasure in this land?"

"I'll go and see why," said the count. At once he sprang upon his mount and with his fifty knights behind him quickly rode away to find the magistrate. When this was done he spoke, "Sir, we would have some fun and this with your permission too. I ask this favor now of you," 
He said, "I gladly shall permit such fun as brings no harm with it; of joy I'm really not a foe.

But here is something you must know.

I certainly shall not allow

a knight into Treviso now with armor on and spear in hand. This is denied by my command.

"Too many strangers journey here; that's why I need to be severe and make each knight obey this rule. In truth, I'd really be a fool were I to let these people arm. It easily could bring us harm; so who would joust must travel thence. Of course, I mean you no offense."

With this he left the magistrate and in a rage he hurried straight to where he found the womenfolk and of his grievance quickly spoke, "You fair and noble ladies sweet, by all your virtues I entreat that you will hear as I complain. The magistrate bade us refrain

"from jousting further in this place. No knight has suffered such disgrace here in Treviso e'er before. He'll not allow it, so he swore, that anyone of us should arm. $\mathrm{He}$ fears the town will come to harm and says he has commanded thus since many strangers come to us."

The women spoke without delay, "He ought to take the ban away. We'll send and ask him to come by and do not think he'll then deny us women such a small request. When we present it in our best and sweetest manner he'll consent to what will make us all content." 
A courier rode away to seek him out and say they wished to speak with him. 'T was then I came inside the city. People watched me ride with music playing as we passed (I'd told them not to go too fast). With happy heart I entered there, greeted by many a lady fair.

I could not help my feeling proud surrounded by so great a crowd, but we got to the inn all right in which I planned to spend the night. The magistrate arrived meanwhile among the ladies. With a smile each warmly welcomed him and said a greeting with her lips so red.

He bowed as does a courtly man. The pretty ladies then began to speak, "You ought to grant us, sire, the favor which we all desire. We hope you'll let the queen fulfill her quest and tourney if she will; we want to see some lances break. You should permit it for our sake."

"I can't refuse you, it appears,

I'll let Count Meinhart break two spears, since all you ladies so incline. Sir Leutfried, Lord of Eppenstein, at once stepped forward from his place to ask of him with courtly grace that he receive this favor too. The women spoke, "Grant it, lord, do!"

"I shall," he said, "but only one.

There'll be no more when this is done." The count meanwhile with joy had gone to get his armor quickly on.

His trappings all were very nice and must have cost the highest price; his clothing was the very best. I'll tell you how this knight was dressed. 
His helmet shone with gold, and it was hard as diamond, every bit. A crest of feathers on the crown, though thick, was almost weighted down with wealth. The feathers' tops were trimmed and all the crest was decked and rimmed with silver leaflets which with skill were tightly bound to every quill.

The cape worn over his cuirass was velvet and as green as grass. The saddle cover too was green and everywhere on both were seen the coat of arms which decked his shield. The heavy spears that he could wield so cleverly were like the clover, his cape, and saddle-green all over.

He had a buckle and a sash and both would brightly gleam and flash; his collar and his hose were good and sparkled just as iron should whenever it's been rightly wrought. The gallant noble feared for nought. He wore two spurs of shining gold. Thus was attired this knight so bold.

The noble Meinhart rode along upon a charger, swift and strong, that leaped and bounded as it came. I heard a lot of folks exclaim with anxious cries, "Get back, watch out!" The rider, though, was brave and stout and had a very knightly air.

The ladies begged him to beware.

I too was ready and was bright in my battle dress of white. The helmet which I wore was crowned and sent a glitter all around. My braids were very long and hung down to the saddle where they swung. A net of pearls enclosed each tress, but one could see them none the less. 
I thus came riding like a queen with woman's clothes and knightly mien. So many folks were in the street my horse could hardly move his feet. Whate'er Treviso's ruler said, although he ordered and he pled that they would clear for us a ring, his scolding didn't change a thing.

I tell the truth when I declare so many folks were gathered there there wasn't any open space in all Treviso, not a place where we could joust or that allowed our steeds to gallop through the crowd. We met upon a bridge at last but even there were people massed.

5I6 Beneath the bridge a river ran. The magistrate at once began to drive the people off. He gained his object; only few remained and we prepared to joust right here. The pretty ladies who were near said prayers that there would be no slips. These came from many rose-red lips.

When I beheld him start his course without delay I spurred my horse. He did the same, and so we two were hurled together, this is true, as if our horses now could fly. Each hand was steady, and each eye; the spears both struck with practiced art right where the shield and helmet part.

The lances made a crashing sound and splinters flew for yards around; his shield struck mine, we came so near. At once each got another spear. Again we jousted, hard and well, and so that neither of us fell. I and this nobleman so bold broke skilfully six spears, all told. 
This done, Count Meinhart, good and brave, untied his helmet. Then I gave

to him a little golden ring,

a gift he was supposed to bring

the lady whom he loved the best

and in so doing manifest

his loyalty and constant mind.

No better token could one find.

520

Sir Leutfried, Lord of Eppenstein, prepared to joust. His clothes were fine and all his trappings, every stitch.

The sturdy man was very rich and known throughout the Mur's high land. The spear he carried in his hand was heavy and was painted red, to show his valor, it was said.

I thought, "He's heavy and robust and certainly knows how to joust." I took a long approach, for speed; his spear dropped down too low indeed and struck my horse's neck. My spear was shattered on his chest. In fear and pain my wounded horse sprang high and quickly on the ground was I.

By then the day was almost past. The jousting had to end at last, and so I hastened to the inn.

The knights would all have liked to win a better chance to look at me but I could never let this be. I hid from everybody's eyes throughout the trip, save in disguise.

The morning after, when the day was well advanced (though I still lay upon my bed) outside the door two hundred women, maybe more, had gathered and they wished to know at what time I had planned to go to church; and, while they waited, some began to ask when I would come. 
As soon as I became aware

that all these women waited there, I dressed myself in clothes so good that any noblewomen would be glad to wear, and this is true. What they were like I'll tell to you: I put a shirt on, gleaming white and rather long, just as was right, and after that a pair of sleeves; no one who's looked at them believes that he's seen others just as nice or prettier at any price.

A lovely skirt I then put on which was as white as any swan. I'm sure no lady ever had a better onc, and that's not bad.

A heavy veil concealed my face for I took care that not a trace of nie should show and none should spy more than the glimmer of an eye. Thus like a woman I was dressed and all I had was of the best. The peacock feathers on my hat were rather dear, I'll tell you that.

I had a glove on cither hand, the best that money could command. I left the room lightheartedly and rosy lips then grceted mc of one accord when I was seen with "Welcome Venus, welcome qucen!" Many were held in high repute and some of them were really cute.

Before we'd gotten on our way Count Meinhart started in to play at knightly games. A tournament began and knightly riders went careering past us on their steeds to show us ladies valiant deeds. The struggle moved from place to place, now here, now there, at furious pacc. 
You must believe that this is so:

At least five hundred knights, I know, were tourneying upon the field.

One heard the clash of many a shield and heard the breaking lances' crash and saw there many a rider dash into the middle of the strife for a ladylove to risk his life.

I asked the knights that they arrest the game. They honored my request; so we went on to church at last. A countess held my mantle fast and sometimes lifted up my skirt that they not draggle in the dirt. Like this she led me to the pew; I took her service as my due.

A priest then sang a pretty mass. The crowd was such I could not pass to go and give my offering. They asked the ladies not to cling so close and let me out and in. I tripped along so feminine they laughed - the women and the men. The kiss of peace was started then.

I got the peace kiss from a book but through my veil, which didn't look quite right. I wished to pass the kiss on to the countess; she said this:

"You'll have to move the veil aside for such a kiss I can't abide." When she spoke thus I did not quail but from my lips drew back the veil.

The charming lady then began to laugh and said, "Why you're a man! I caught a glimpse of you just now. What then? I'll kiss you anyhow.

From all good women everywhere I'll give a kiss. Because you wear a woman's dress and honor thus us all, I'll kiss for all of us." 
When she spoke up so merrily and took the kiss of peace from me my heart and mind were filled with bliss for joy is but a lady's kiss.

I'm sure that everybody who has kissed a lady knows it's true, that there's no pleasure so complete as kissing ladies fair and sweet.

The mass was over soon and I with many a pretty one close by went from the church but then we found a teeming throng was all around, the streets were swarming with the crowd. Before us ladies, long and loud, a mighty trumpet blast rang out; the throng was pleased without a doubt.

S42 We came back to the inn again and at the door I parted then from all that lovely company, I was as happy as can be.

That God would care for me they prayed and from their hearts invoked His aidit's brought me luck in many a task. God grants such ladies what they ask.

To the Piave rode our band where, on a pretty meadowland, I saw awaiting me a knight. I recognized him at first sightSir Reinprecht von Murecke, a name that all fair ladies should acclaim for he made all of them his own and seldom ever slept alone.

The wealthy man was of this ilk. His shirt was made from finest silk and it was just as white as snow. No other armor did he show but only helmet, spear, and shield; clad thus he galloped down the field. His horse was seen enveloped in rich velvet cloth and baldachin. 
I had to change my clothes, of course; he stopped and waited on his horse.

It was no time at all, I guess, till I had on my battle dress.

I tied my helmet with a band and took a goodly spear in hand (of middle size and painted white). The prospect filled me with delight.

His reins were hanging loose and low, his spear gave off a golden glow, beneath his arm he let it lie; I held mine upright on my thigh. His spear came through my shield and broke to many pieces with the stroke; I never lowered mine to thrust. That's how we both performed the joust.

We did as well as any can. I gave the very wealthy man a little ring which was of gold; he earned it well, as I have told, and tendered me the thanks he owed. Hermann von Plintenbach next rode against me, three Italians then, which made them happy-hearted men.

They all rode daringly and well and since no rider missed or fell to each was readily allowed a ring, of which they seemed quite proud. I broke a spear with every one and just as soon as this was done we hurried on so that I might within Sacile spend the night.

No better welcome could one find for all the balconies were lined with ladies. I was well received and didn't feel at all aggrieved. I went to bed and rested from the journey. When the day had come I rose at once, made haste to don my battle dress and travelled on. 
Before a very pretty wood already waited then the good Meinhart von Gorze and a lot of knights whose names I've long forgot. Twelve were wearing helmets then; as I saw this I told my men, "Here are some knights who want to joust. We'll give them what they like, I trust."

I changed my horses speedily, they handed up my shield to me, I quickly bound my helmet fast, and took a spear in hand at last. Meanwhile the knights had ridden near. The count broke off a shining spear when it upon my helmet smoteI shattered mine against his throat.

Seven lances broke that day on me and in as skilled a way as any noble could desire.

With spirits rising ever higher I broke eleven, quite a few, and in a courtly manner too.

Five knights there were who failed to hit me square and got no ring for it.

When I stopped jousting and unbound my helmet, quickly all around a lot of other jousts began.

The Count of Gorze struck a man and knocked his helmet off. I know I never saw a finer blow. The fellow almost lost his seat and fell beneath the horse's feet.

A hundred knights were on the field to show their skilfulness and wield their lances in the courtly game. For love of ladies and of fame some gallant men so bravely fought that they served ladies as one ought. This knight was glad, another one had only grief when all was done. 
I had to leave, for it was late.

The knights began to separate;

some were so kind and courteous

they rode to St. Odorico with us-

' $t$ was there I planned to spend the night.

The next day, when the morning light drove off the darkness with its power, we didn't tarry there an hour.

I quickly put my armor on and shortly afterwards was gone. I sought the field with spears of white and wished to joust with any knight who'd come to serve his lady fair. One knight, of whom I'd heard, was there who had with him his lady's veil. He'd want to tourney without fail.

Sir Otte von Spengenberg was he, a noble knight, who rode toward me with gleaming armor, richly dressed as fits a lady's suitor best.

His trappings glittered far and wide, around his helmet there was tied a veil of an expensive kind, and thus came he of lofty mind.

We both would serve a lady dear; each had a very heavy spear and wished to ride a lengthy course. He hoped to knock me from my horse and I thought also, "When we meet I'll see if he can hold his seat. He will if he would keep his name untouched by either scorn or shame."

Toward me the rider quickly swepthis spear sank low the horse so leapt. I turned a little from the man (to knock him sprawling was my plan) and swerved back onto him again; I struck him in the collar then. I turned and jousted with such skill Sir Otte almost took a spill. 
You can believe me that he broke a sturdy spear against my cloak and with the lances' crashing sound a lot of splinters flew around. His reins and stirrups at the blow were lost. He seized the saddlebow at once and with its help could rise. $\mathrm{He}$ would have fallen otherwise.

Five others followed, all did well. They broke their spears and no one fell, so I gave each of them a ring and then untied my helmet string for at Gemona we should stay. A knight was waiting on the way. He had a handsome tent pitched where it overlooked the thoroughfare.

Sir Mathie was the noble's name. He strove for honor and for fame and many virtues he displayed. He sent to me a lovely maid who met our company before we'd travelled far. A lance she bore in hand and rode a pretty steed. Her clothes were very fine indeed.

This pure and charming maiden said (on seeing me) with lips of red, "Queen Venus, let me welcome you! Sir Mathie sends me hither to announce from him that hereabout you're really welcome. There's no doubt he's glad to see you. Know that I tell what he said and not a lie.

"My lord has also sent me here to bring you, lady fair, this spear and, as his messenger, request that you would break it on his breast. This favor he commanded me to ask with every courtesy. So take it, lady, if you care to honor women everywhere." 
I took the spear which she had brought and thanked her warmly, as one ought, for bringing me these words. I bade a servant say that I'd be glad to grant the favor she did ask and willingly perform the task. The maiden thanked me much for this and then departed, filled with bliss.

I armed myself when she was gone. I tied my helmet firmly on and quickly seized a spear and shield. Then he came riding o'er the field. ' $T$ was thus that I first came to know this knight who longed for honor so. His dress was costly at our meeting; he well deserved a lady's greeting.

We soon were not so far apart and it was time for us to start a charge or it would be too late. Both his concern and mine were great that his should be a pretty joust and that he'd not fall in the dust. We spurred together for the stroke and neither spear remained unbroke.

The joust was splendid, I declare.

I knocked his helmet through the air. The veil he'd fastened to his lance was hanging from my shield, by chance; a broad and gaping hole now marred the shield where it was meant to guard the shoulder bone on my left side. It was a joust to suit his pride.

He got his helmet back again. I noticed others riding then toward me, a half-a-dozen strong. The spears were neither thick nor long which each one carried in his hand. In turn I jousted with the band and did not miss a single one. Four had struck me when all was done. 
That eve while resting at an inn I saw knights coming to begin a combat, which was very good. They rode as well as any could and tourneyed right in front of me. No knightly game could ever be more lively or reveal more skill. I watched it from my window sill.

And when at last the game was o'er at my command a servant bore the knights good wine, and quite a lot, for after labor men have got a thirst. I treated every soul in goblet, cup, and silver bowl. They bowed to me with courtly grace and went to find their resting place.

My steward took four dresses out to have them washed some place about. A lady learned to whom he went; at once the lovely lady sent the laundress who was there a dress and bade her by her happiness to hide it under those of mine. On it there was a buckle fine.

A jeweled band, a belt, a note were wrapped therein. Though she who wrote and sent the gifts was virtuous, without my will she acted thus. The clothing then was folded so my steward wasn't apt to know all that was there. And so he brought away more dresses than he thought.

He took the gifts with my attire, for which he later earned my ire. Night passed, the sun came into view. I went to church but no one knew.

On my return I soon was clad in battle dress, the best I had. I never until then had worn such splendid things as on that morn. 
My buglers played a melody, a pretty tune in a treble key, and thus they told all people near that I was shortly to appear.

Then many a proud, high-minded man in battle dress at once began to leave the houses. They revealed themselves with helmet, spear, and shield.

Thirty knights or more soon came out of the town to start a game. In fine array and galloping they spurred their horses to the ring. The men fought well on either side and many noble riders tried to break their store of spears in haste. The tourney's object was this waste.

The knights were jousting all around till splinters almost hid the ground and several shields lay there as well which during fierce encounter fell. I charged eleven knights that day and broke a lance in each affray but two. I finally untied my helmet band and rode aside.

To seven knights could I accord a ring. ' $T$ was thought a great reward and those who won the prizes then by jousting well were happy men, but those whose lances hadn't broke seemed angry every time they spoke. That they had missed me and thus had not won a present made them sad.

Gemona soon was left behind and many nobles I had wined took leave with knightly courtesy. The ones who came with us were three: Sir Heinrich of Lüenz rode along and two Italians, brave and strong, whose names I now cannot recall. Good men they were, respected all. 
At Chiusa I passed the night and just as soon as it was light I tourneyed with Sir Heinrich, who was praised by all, as well I knew. So were his fellows; those who served me gave them rings, which they deserved. And so in company like this six lances broke without a miss.

That day my heart could feel no woe.

We travelled to Tarvisio but there I found no jousting since Carinthia's most noble prince had conquered in the selfsame night with all the country's martial might a Castle Goldberg. He employed his men to have the place destroyed.

I went next morning with the dawn before the city. Resting on

a pretty meadow, broad and green, the vassals and the prince were seen. They'd halted to have breakfast there; he liked to eat in the open air. At least a hundred knights, no less, were with their ruler, I would guess.

The prince and vassals on the ground then heard my bugles' piercing sound. They asked, "Who's coming to us, who?" One said, "The queen is passing through just as her letter said she would." Another spoke, "She's welcome! Good! We'll receive her very well." Their reception thus befell:

The prince and all his company together warmly welcomed me in Slavic, "Venus, may our God receive you!" With a friendly nod I returned the greeting of the men. They had my servant ask me then if I had come to them to joust. I answered, "Yes, and soon, I trust." 
Many a good and sturdy man arose directly and began to arm himself and soon were dressed full fifty riders in their best.

All wished to tourney, it was clear; each quickly got a shield and spear. I too was now prepared to ride and filled with confidence and pride.

The first to come was richly decked in all the splendor you'd expect of one of the prince's favorites. Sir Hermann, Lord of Osterwitz, thus was the kindly noble named. For many virtues rightly famed, a man of spirit and desire, no one could value honor higher.

We charged as though we wished to slay each other there. "Give way! Give way!" I heard the knights around us shout. It was a most successful bout: they all could see the lances break against our heads, and no mistake. The sparks flew from our helmet so the others thanked us for the show.

I got another weapon from my squire at once. The next to come at me was Kol von Finkenstein. His joust was also very fine.

It certainly was not by chance that he so deftly broke his lance against my helmet; he could wield a spear! I broke mine on his shield.

I'll tell you how it went in short and yet shall give a true report. On me broke fifteen spears before the morning ended and no more. The knights who held them jousted well; if I the names of all should tell to whom their ladies' thanks were due my tale would be too long for you. 
Eighteen lances for my part I broke and with a happy heart at last untied my helmet strings and quickly gave out fifteen rings to those who'd jousted well that day. This done, I started on the way to Villach and without a care.

The folks were glad to see me there.

600

The rooms at Villach which we had were very nice, and I was glad. At dawn I left the inn to pass a morning hour hearing mass; in woman's clothing I was dressed and wore, of course, my very best. I tripped to church so merrily that many had to laugh at me.

601

When I returned from there I ate my breakfast. Since it wasn't late I looked to see what I should wear the next few days. Without a care, my heart was light, my spirit gay. 1 checked on all the skirts that lay in front of me, and all was fine till I found one that wasn't mine.

602

When I beheld it on the bed I called my steward in and said, "Now tell me who has dared to give me this, if you would like to live." He spoke, "My lady, I don't know. I think it most peculiar though. Who gave the skirt and who could bring it so you'd not observe a thing?"

603 Without delay I then unbound the skirt and this is what I found: a buckle, belt, and jeweled band; I've ne'er had finer in my hand. There was a German letter too which made my wrath break forth anew. I told the steward then, "You should believe, for you this means no good." 
"My dearest lady," he replied,

"do let your anger now subside.

I do not know (and hope to die

if this is false) who brought them by."

I took the letter, opened it,

and had him read what there was writ.

He read the message, which explained

the presents. Hear what it contained:

"Noble Venus, I extend

a greeting and would like to lend

to you my service faithfully.

All ladies everywhere should be grateful that you in friendliness

have put on you a woman's dress and thereby honored womankind. May all our praises be assigned

to you. I hope that you will prize these gifts of mine and not despise what I have sent for love of you.

I must remain unknown, it's true, because discretion counsels it.

If you are honored, I admit

that I am happy, very much, my thought regarding you is such.

God guard your honor, stand beside you, and on your knightly journeys guide you, may nothing needful be denied you."

Just as I heard the letter read

a messenger appeared and said to me, "Most noble queen, I'd say you ought to arm without delay. And I must tell you anyhow, the knights are all quite ready now and riding to the field nearby.

Their messenger to you am I." 
I spoke, "I'm glad that they are here."

I put my armor on with cheer and soon was all prepared to go in battle dress as white as snow. I rode at once into the field and found with armor, lance, and shield some forty knights awaiting me.

That they would joust was plain to see.

"Crash!" and "Crash!" It filled the air upon the common everywhere.

The riders tourneyed fast and hard; the ground was covered with many a shard. I broke a spear at every run, fifteen in all; when this was done I went back to the inn again and sent twelve rings out to the men

who'd earned a prize from me that day. I put my armor all away and donned a woman's dress and hat and on the balcony I sat.

But when they saw me--listen well and you shall know what then befella knightly game of war began, including every single man.

6I3 The evening now began to fade. From early morning they had stayed in armor which was hard and tight and many of them longed for night who suffered much from weariness. Yet others there felt no distress and wished to serve their ladies more, but darkness fell; the game was o'er.

6I4 The next day was the third, and I soon was ready to say goodbye and with my train to journey on. I was quite anxious to be gone and in a happy frame of mind when we left Villach far behind. Twenty good nobles with me rode to Feldkirchen, my next abode. 
A lot of people were aware of when I'd promised to be there. They rode in from the countryside to see me, came from far and wide with shining armor and richly dressed. I'll name you several of the best. To joust with me came Sir Gottfried von Havenerburg, a knight indeed.

His brother, Sir Arnold, also came. It wasn't long till both could claim a ring; ' $t$ was earned with a valiant thrust. Sir Kol von Treven was there to joust and Bernhart and Ulrich von Treven too. Von Himmelberg, a noble who (the bold Sir Zacheus was he) was known for song and poetry,

had come there wearing on his back, over his armor, cloth of black. He wore a monk's cape; it was big and on his helmet was a wig in which a tonsure had been shorn. With many oaths the knight had sworn he'd knock Queen Venus from her horse, and that was his intent, of course.

I faced eleven knights, and they had skill and courage to display. I broke a spear on each of ten, and every one of these good men broke off his lance on me. That's right. I then beheld the monkish knight; he rode toward me inside the ring but that was quite a useless thing.

6 i9 When I beheld him coming so I took my helmet off to go and sent a messenger to tell him, since he liked such cloth so well and seemed a monk and not a knight, the queen did not believe it right to joust with him. Chivalric sport was not for people of his sort. 
where food and ease awaited me.

I went to bed when day was done, and in the morning as the sun shone brightly down I journeyed thence. The monk had caused me some offense and I took care my anger showed. Ere long into St. Veith we rode.

While we were still some distance out my coming was proclaimed about, and some decided not to wait but welcome me before the gate. Their joyful greeting I commend; they met me as one meets a friend, their words were courteous and good. I bowed as warmly as I could.

We rode to town with great delight. I asked a servant bid who might desire to joust with me begone and come back with his armor on. At this the nobles all were glad, and twenty-five of them soon had armor and spear, and would employ them both to seek renown and joy.

625 At once upon the field I came and found the ones who longed for fame awaiting me with shield and spear so they might do some jousting here. Without delay I took a lance and saw a worthy knight advance, Sir Reinher von Eichelsberg was he, a man of honor and honesty.

626 We both performed a pretty joust, and neither tumbled in the dust. We proved ourselves both sharp of eyethe splinters of our spears flew high. As soon as this fine joust was through Sir Konrad von Lebnach rode into the circle; brave and in the prime of life, he won much praise in time. 
Then came Sir Kone von Friedberg, in might and skill with arms a noble knight but not with property or gold (that's what those who knew him told). Sir Jacob von Berg who spent his days in seeking for renown and praise tourneyed with me and won a prize. Sir Konrad von Teinach did likewise.

The monk appeared again at last inside the circle. He held fast a heavy weapon in his hand; to joust with me he took his stand. When I beheld the monkish cloak and recognized him, thus I spoke, "I shall not meet you, I declare and truly, here or anywhere."

I took my helmet off and went to the inn, where I could rest content from all my labors. There I lay until the breaking of the day. We packed to leave; but, nonetheless, I first put on my battle dress and asked a squire to find out how the knights would like to tourney now.

632 When my intentions were revealed they came with helmet, lance, and shield. Six were waiting and no more with spear in hand before the door, ready for jousting to begin.

When I beheld them from the inn, each one as eager as a squire, I thought, "You'll get what you desire."

At once I took a spear in hand to joust the first one of the band; it was Sir Ortold von Osterwitz. His lance and mine were broke to bits and splinters scattered high and low we raced against each other so.

The joust was good, both lances smote and shattered squarely on the throat. 
Sir Wichard von Karlsberg took his place but rode at much too slow a pace and didn't break his spear on me. The next one galloped valiantly, Sir Engelram von Strassburg; I rode just as fast and that is why his joust soon brought him his reward. Then came Sir Engelbrecht, a Lord

of Strassburg and a worthy knight to whom high praises brought delight; his manners were refined indeed. The next to joust was Sir Siegfried, the Saxon, as the lord was named, who in Carinthia was famed and truly never did amiss; he won a lot of friends for this.

636 Once more the knight in monkish guise appeared. He hoped to win the prize from me of all the goods I had. My messenger did as I bade and quickly went to him to say that while he wore a monk's array I would not meet him, for it must offend my honor should we joust.

The monk addressed the messenger, "Then I shall follow after her to every place she may appear, none has the right to interfere. She's going to prove to me her skill; I am determined that she will, and only death can hinder it.

No pain could change my mind a bit.

638 The knights were very courteous but came to me and all spoke thus, "Lady, we pray that you'll allow that we politely beg you now to grant the wish of this monk here and, jousting with him, break a spear; for, no matter how he's dressed, he seeks for honor as do the rest." 
I said, "Since you have asked me to I'll grant him this, but just for you. I got a spear and rode my horse where it could run a lengthy course. You can believe me when I tell you that I did not like him well and was resolved that I'd take care to strike him on the head, and square.

I'll tell you quickly what transpired. He broke his lance as he desired, but I delivered such a blow he landed in the dirt below and lay unconscious from the fall, which didn't worry me at all. Many were glad of it; thereafter his fall provoked a lot of laughter.

I'd struck his helmet as I'd planned with all the strength at my command. To him and to the others I gave fourteen rings and said goodbye. I left the city and began my journey as a happy man. We came to Friesach-in the gown of Venus I rode into town.

The knights were riding with a will and wielding spears with knightly skill, a lot of shields were broke that day. The noble riders' courtly play continued till ' $t$ was almost night and all their steeds with foam were white. When day and evening both were past the knights gave up their sport at last.

646 But soon enough the night was gone and with the coming of the dawn once more they dressed them for a game in armor, and I did the same. Onto the field we hastened then; I was the happiest of men since I could serve my lady fair that day before the nobles there. 
On the field before the gate I saw Sir Konrad von Nidecke wait, adorned as worthy knights should be. He made a gallant charge at me, his course was long and did not waver, he sought to earn a lady's favor and spurred his charger to great speed. Mine too was not so slow indeed.

648 I'll tell you how the tourney went. He broke his spear just as he meant and on my throat I felt it land. I wounded him in his right hand, which really caused me great distress because of his true nobleness. He was a valiant knight, it's true, fearless and manly through and through.

649 Sir Otto and Sir Dietrich, Lords of Buches, earned them no rewards and there were angry murmurings because they both had lost their rings. Their hearts were-strongly set on gain; they wished for riches more, ' $t$ was plain, than lover's pay of any kinds.

Broad fields and meadows filled their minds.

$650 \quad$ On seven knights I broke a spear and promptly journeyed forth from here. Five golden rings to them were sent. who'd jousted well before I went along toward Scheifling with my band in Styria, a lovely land.

Nineteen nobles travelled down with us. Five waited in the town.

652 In Scheifling then I passed the night. When it was banished by the light of day I rose and soon was dressed in armor, as were all the rest who'd come to share our knightly sport.

On all of them the richest sort of robes and armor were revealed. At once we hastened to the field. 
Of such as these I'm glad to tell.

The first had clothed him very well as any courtly noble must who knows good manners and can joust. Sir Ilsung von Scheifling was his name; his heart has never ceased to claim those things which make one good and wise. He sought to win a worthy prize.

Five hundred bells and maybe more the lofty-minded noble wore.

With little bounds his charger sprang and as he moved the metal rang until one couldn't hear a word. The gleaming gold and silver sherd was on a red and green brocade and all was very nicely made.

655 My countryman was decked so fine that not a knight along the $\mathrm{Rhine}$ was ever better dressed, and few as well; what I have said is true. The spear he carried in his hand was decorated with a band to which were fastened bells, but all of these were really very small.

656 So often and so well he strove that one might call him Waste-The-Grove. He spurred his horse into a race and then a pretty joust took place. My shield went flying with his stroke, for all the thongs which held it broke. Like thunder did the joust resound; the shield was lying on the ground.

My spear was snapped in two on him just as a dry and heavy limb bent down and broken from a tree. I do not think there'll ever be from jousting such a mighty crack as sounded forth from our attack. The bells flew all around like dust, the shields were shattered by the joust. 
As soon as this fine course was run four others followed, one by one, and then I gave away five rings. I heard them say, "Queen Venus brings us on her journey sport and cheer. God has preserved her well till here; may He protect her from all foes in tenderness where'er she goes."

Toward Judenburg at once I went with spirits high and pleasure bent, but still I wished that things were so that my dear lady fair might know how she had occupied my mind. For I thought thus, "She is so kind, if she discovered how I felt toward her alone her heart would melt."

In Judenburg they greeted me with eagerness; immediately I thanked them with a friendly air. They gave a hearty welcome there. I had a quiet place to stay that night and with the break of day I donned my armor, bright and strong. I didn't wish to tarry long.

Bedecked I rode onto the field where nine good knights also revealed their costly trappings, arms, and dress. They were the soul of courtliness. I broke nine spears on them, and this was done without a single miss. Three knights missed me, their aim was bad, which didn't make them very glad.

662 I gave the six the rings I owed, and then without delaying rode toward Knittelfeld, with joy to tour on down the valley of the Mur. The morrow came and then I broke two spears soon after I awoke and gave two golden rings away. My thoughts dwelt on a lover's pay. 
To Leoben I travelled then and found there twenty noblemen awaiting me with spirits high. When we rode in the city I was well received by every knight for all were friendly and polite. The courtesies which there I viewed deserved in truth my gratitude.

664 Dismounting at the inn at last, I rested till the night was past. That morning when the sun arose, from every alley, I suppose, I heard the flute's delightful sound and saw the knights from all around gayly to a meadow streaming with rich apparel brightly gleaming.

I rode upon the meadow land and took a shining spear in hand. Sir Dietmar von Steier was to face me first; he galloped to his place. We came together at great speed; you should have seen our spears indeedwe both had struck so hard and well in tiny bits to earth they fell.

Then came Sir Siegfried von Torsiol; he had a brave and manly soul, and all his limbs were tough and strong. $\mathrm{He}$ never did one any wrong and acted as a noble should. His joust with me, of course, was good. Both of our lances broke thereby; all there could see the splinters fly.

I'll tell you all, but make it short; while we pursued this knightly sport were thirteen lances broke on me. Since I'm to tell it truthfully, I missed three times in tourneying. At once I gave each knight a ring who'd jousted well and so had won a prize from me. When this was done 
we journeyed on from Leoben's walls to where the Mürz's water falls into the Mur with rush and roar. They catch the fish there by the score. Now up the stream I rode until a castle towers on a hillKapfenberg-high and alone. In all of Styria it's known.

670

The master of it was a lord whose will was constantly set toward the things a noble ought to do to win acclaim; all these he knew. $\mathrm{He}$ was generous, his name was guarded carefully from shame; he was dauntless and well-bred. I haven't lied in what I've said.

He followed honor faithfully. Sir Wülfing von Stubenberg was he and rich in people and in lands; he had those things which wealth commands. Sir Wuilfing, when he came to know of my arrival down below, declared, "As soon as I have seen her I shall greet the noble queen."

678 When he was ready to receive me thirty knights (so I believe) came with him. Down the hill they rode, well-clad and in the courtly mode. Before I travelled to this meeting I'd never had a warmer greeting than I was given by this knight at Kapfenberg. While it was light,

unarmed, but dressed in bright array I sought the place where I would stay and rest in comfort till the dawn. When day had come and night was gone I put my armor on again. My longing, loving heart was then filled with gladness and content, which made itself quite evident. 
When I was clothed and at the last had tied my helmet on me fast I rode to the field with festive air. The Knight of Stubenberg was there and was in all so richly dressed that I was very much impressed. His splendid armor gleamed on him and nearly made the sun look dim.

The proud and gallant noble rode toward me, and all his trappings glowed as if he came from heaven's door. His skill had many times before won highest praises, I'd been told. His course was very swift and bold; his horse so close to mine was guided that he and I almost collided.

The points of both our spears were thrust right through our bucklers with the joust so that a noisy crash rang out and bits of lances flew about as well as parts of each man's shield. His sleeve as well as mine concealed a bruise; some rings of armor fell. The joust was ridden hard and well.

684 A lot of spears were shattered then; I broke a dozen on the men. It went as I had wished it to and I'd not missed when we were through. The worthy nobles rode at me twelve times and each so skilfully that no one failed to break his spear. Twelve golden rings I gave out here.

I had a place to spend the night. As soon as all was clear and light and sunbeams shone on everything I climbed across the Semmering to Gloggnitz on the other side. I found six nobles there astride their mounts who wished to try their skill and I was quick to do their will. 
They rode toward me with armor on;

I had not waited long to don a rich and splendid battle dress.

Von Ringenberg with full success broke off a spear on me. The one I jousted with when this was done I knocked down backwards off his horse, which made him feel ashamed, of course.

The spears I broke then numbered four. On the field had come no more with armor on and lance in hand and so I stopped. At my command the servants gave six rings away. I sought the inn where I should stay and found a pretty hostel there; I got some other things to wear.

I changed my clothing under guard, and then the hostel door was barred. I took with me a servant who would not say anything, I knew. We stole away without a sound and rode with joy to where I found my dearest wife whom I adore; I could not ever love her more.

She greeted me just as a good and loving woman always should receive a husband she holds dear. That I had come to see her here had made her really very pleased. My visit stilled her grief and eased her loneliness. We shared our bliss, my sweet and I, with many a kiss.

She was so glad to see her knight, and I had comfort and delight till finally the third day came; to give me joy was her sole aim. When dawn appeared it was the third. I dressed, an early mass was heard, I prayed God keep me from transgressing, and then received a friendly blessing. 
Right after that I took my leave, lovingly, you may believe, and rode with joyful heart to where I'd left my servants unaware.

I entered Gloggnitz hastily and found them waiting there for me, prepared to journey on again. At once we left the city then.

We rode to Neunkirchen gaily decked and were received as I'd expect of those whose manners are refined. Each knight was courteous and kind who waited there with spear and shield. When I came riding on the field I found them all prepared, adorned with trappings no one would have scorned.

Nine waited there, not more nor less, to joust with me, in battle dress. I saw them and it wasn't long till I'd donned armor, bright and strong. The first to come I'd heard much of; his great desire was ladies' love. It was Sir Ortold von Graz, a name already widely known to fame.

All that he wore was of the best. The good man cut me in the chest so strong and skilful was his joust; through shield and armor went the thrust. When I beheld the wound indeed and saw that it began to bleed I hid it quickly with my coat before the other knights took note.

I broke nine lances there in haste and found my inn. I dared not waste much time before I got in bed. I sent nine rings of golden red to each of them who with his spear had earned from me a present here. My injuries were deftly bound by a doctor whom my servants found. 
His presence there was soon found out; ere long the tale was spread about that Venus had been wounded sore and so that she could joust no more. The knights were sad to lose their sport, but when I heard the false report I said, "Tomorrow I shall stay a while ere going on my way.

"I'd like to let the people see the truth in what is said of me and know that I am well and strong. Although the tale is not all wrong this little wound will quickly heal and I can easily conceal it so that none will be aware that I've been injured by a hair."

There it was I spent the night, but when the second day was bright and when the sun shone in the skies I did what I considered wise and donned my woman's finery to look as pretty as could be in lady's dress as white as snow. I went to church so all would know.

Whoever saw me gaily walk to church that morning thus would talk, "It must be false what people tell; this queen is light of heart and well, her thoughts are gay, her step is strong." I left the church with such a throng around me when the mass was o'er that truly they knocked down the door.

To serve my love and lady then I would have liked to joust again but found that all the knights were gone, so joyfully we travelled on till Wiener Neustadt was in view. I'd often told my retinue, they need no gaiety suppress:

"Good manners go with happiness." 
And thus I entered with my train the town. I called my chamberlain and bade him have someone prepare a water bath for me somewhere outside of town and tell no one. I came as soon as this was done, got in the bath my man had hired and soon forgot that I was tired.

When I climbed in and sat me down my steward started back to town to go into the inn and find some clothing he had left behind. In truth you must believe me that without a servant there I sat which makes me think at any rate that what's to come will never wait.

And I believe without a doubt that what's to be will come about. I learned then some of what this meant and now I'll tell you how it went. As I was sitting there alone a page came up I'd never knownclever, courtly, and well-clad.

I'll tell you what the fellow had.

This smart young man, without a sign or word, put down a carpet fine; before my bath the carpet lay. He placed thereon a woman's array: a skirt, a heavy veil were there (there were no better anywhere), a belt as nice as I have seen, a buckle which would suit a queen,

732 a head-band, bright and glittering, a ruby set into a ring, red as a lovely lady's lips which wound a heart the while it skips. He placed a letter on the stone, with pretty words it should make known the one who sent these gifts to me, so he informed me carefully. 
When I beheld them by my bath my mouth spoke up with honest wrath, "Say, to whom were these things brought? I'll tell you plainly. I've no thought, believe me, either clothes or gem, of taking even one of them.

So take them out, whate'er you do, for I am really vexed with you."

The page departed unconcerned but with two others soon returned who bore rose petals, gleaming red, and these, without a word being said, were scattered on me by the youth until they were so thick, in truth, that bath and I were covered o'er. He would not utter one word more.

Despite my pleading and my rage I got more petals from the page so that the floor around was soon quite lovely with the petals strewn. Thereon he bowed and, though he heard a lot from me, he said no word but only turned and went away. I'd never seen him till that day.

736 He left me angry and harassed. My chamberlain returned at last and brought a robe and towels to dry me with. He saw the gifts nearby and spoke, "My great and noble queen, what's this? And what do these things mean? But you're completely covered o'er and roses color all the floor!"

I told him, "You're to blame. 'T was wrong to leave me all alone so long and it's a fault I must condemn. Some pages brought these things with them: the roses, jewels, and the dress.

The youth who led them, I confess, I do not know, neither his name nor the place from which he came. 
"This makes me very angry still for every bit against my will he laid these things down by my side. Such deeds as this I can't abide and never saw before, I vow. But just give me my bathrobe now; there'll be no bath for me, and I shall leave these presents where they lie."

Then spoke my chamberlain to me, "Good lady, no, that must not be. It truly would be wrong, I fear, were you to leave these presents here. Those working in the place would claim them and would soon find out the name of her whose love has sent them. No, 't would not be right to leave them so.

"Perhaps she has a lot of friends, then you might never make amends if you should cause her any pain by letting what she sent remain in here. So let me keep this prize, in truth I think that this is wise. And hear, it's also good for you to be most careful what you do,

"that you protect yourself and her for it may be a messenger will come and tell you who has sent the gifts which you so much resent and you can then return them still. Let me advise you if you will. She's fond of you, that one can tell, for this one ought to treat her well."

"I'll let you take the things away

but take them only that I may, just as soon as it is known who sends me clothes and precious stone, return the presents I receive;

and this you may as well believe. I can not keep a thing they've brought or else my constancy were naught. 
"I've always heard that no one can give to a woman or a man a present quite against their will. My mind would certainly be ill should I accept what one bestows who's not the lady that I chose to be the one for whom 1 live. I want what she alone can give."

I left the bath house then and rode in secret to the town and strode into the inn where I should stay. I didn't go outside that day and wore a solemn face long after for angry spirits bear no laughter. This truth I easily could guess in seeking that day's happiness.

I thought, "I'll get someone to read the letter. It may be indeed the lady's name is written there." ' $T$ was read to me and, I declare, that note did credit to the sender. It's greeting, though it was quite tender, did not affect me much when read, but listen to what the letter said:

"Lady, could I shape the phrases to greet you well with sweetest praises, I'd do it, on my word, serene Venus, fair and noble queen. Because of your nobility true service you shall have from me. For well do you indeed deserve that noble women all should serve you with praise unceasing, your honor thus increasing. To honor you have turned each thought and so to you my gifts were brought that both of us may gain more honor. Lady, deign to keep the presents I impart, remembering your kindly heart. 
They're sent to you for honor alone and I desire to be unknown because I must be circumspect; may you, dear lady, not object. If my wishes might come true and should my eyes soon gaze on you then I myself will let you know why I have sent these presents so to you, my dearest lady fair. I now commend you to the care of Him who came our ways to straighten and whose power conquered Satan, our adversary grim.

May He take you to Him

and give you many honors here;

this is the hope sincere

of my heart and mind.

In my loyal heart I find

a wish that you will reap the best on this honor-bringing quest."

What more is there for me to say? I felt sorrow and dismay, with anger I was quite distressed and got that night so little rest that I was rather ill and worn. But with the coming of the morn I heard an early mass and then festively set out again.

Toward Austria and down the plain I led a very courtly train.

When we approached the Piesting Stream of shining shields I caught a gleam. Soon after there appeared in sight well-trimmed helmets and spears of white. The nobles riding toward this meeting received me with a friendly greeting. 
The names of some of those I'll tell who welcomed me that day so well. There were some thirty men of horse, and one was called Sir Wolfger von Gors.

So virtuous in deed and word was he that I have never heard a thing of him that one could blame. $\mathrm{He}$ strove for honor and for fame.

The worthy man addressed me there, "My noble queen and lady fair, I come to bring you a request and hope to find my suit is blessed. I ask, dear queen, that you let me become one of your company and through your grace would I obtain the office of a chamberlain."

When I had heard this gallant man Sir Gottfried von Dozenbach began (a noble fit for any task), "Now listen to the boon I ask. I come here at my lord's command to bid you welcome to this land with God, and bring a greeting from my lord, who's glad that you have come.

"Von Regensburg sends it by me. The bishop's governor is he and one who values honor too. Whatever he can do for you you may be sure he'll not be loath to do; on this I'll take an oath. He'll serve you faithfully and for the ladies' favor, nothing more.

"He bids me say that he aspires to serve you and that he desires, most noble queen, that you allow him to be your marshal now. He's rich in property and thought, and he will serve you as he ought. Your worth is such he would persuade you, lady, to accept his aid." 
I had a servant answer then that I'd be glad to have both men: "But he who seeks an office here will need to earn it with a spear and have such skill and temperament that he will never need lament because he didn't joust aright. My office is for such a knight."

Sir Wolfger von Gors spoke right away, "Lady, what more is there to say? Your court is stately, one can win great honor for himself therein. Should I become your chamberlain, I'll hold the post without a stain and shall receive it through my skill at jousting anytime you will."

“. . . [two lines missing] . . .

There at Traiskirchen we can joust. In virtue you have put your trust and are a noble of the sort I like to have about my court. You serve the ladies well, and my respect for you is very high."

The good man thanked me then and bowed with gratitude, for he was proud, and rode off quickly. He was bound for Traiskirchen; it was there he found his armor and his battle steed. Soon he was well attired indeed and like an angel to behold. He wasn't one to save his gold.

When he rode away from me, von Dozenbach spoke courteously, "My gracious queen, by all adored, what message shall I bring my lord from you? I pray that you will show your kindness and will let me know, for here I've nothing more to do. My lord will gladly joust with you." 
"Tell the governor from me, would he serve ladies faithfully, then he may join my retinue. But if he'd be my marshal too then he must joust and break his lance; his honor he may thus advance. I'll gladly place him in this post if honor's what he wants the most."

The courtly noble didn't wait but rode to Vienna to relate to Regensburg without delay the message given him to say. His lord was pleased and spent the night to see that everything was bright which he and all his riders wore. They were adorned as ne'er before.

But meanwhile I had ridden down to Traiskirchen. Just before the town I found awaiting me someone who never in his life had done unknightly deeds. It was, of course, the good Sir Wolfger, Knight of Gors. His armor gleamed from sunny skies and threw their radiance in my eyes.

I saw him and made haste to don my armor, tied my helmet on, and soon was splendidly decked out. "Give way, my lord!" I heard the shout and cries of pleasure filled the air from all the nobles gathered there. We charged at once with leveled spear; as soon as I had galloped near

to him I spurred to greater speed; he also quickly urged his steed. We rode so closely in the joust and were so skillful in our thrust that both his shield and mine were shattered to pieces which were widely scattered. Against the helmet each man broke his lance in splinters with the stroke. 
And so it was my chamberlain received the post he wished to gain. Some other knights opposed me then in courtly manner; there were ten, and seven of them soon were hailed by those around, the others failed to break a spear; their joy was small. I broke eleven spears in all.

I had my servants quickly bring to each of seven knights a ring; Sir Wolfger also got his prize. He was a courtly man and wise who liked good men and, I've heard tell, could also please the ladies well, and with the world it was the same.

He was a man whom none could blame.

Such was this chamberlain of mine.

His servants all looked very fine for they as well were richly clad, and very courtly dress they had. On foot the noble came to me and took my armor so that he could have a servant clean it right; he ordered him to get it white.

On foot he led my horse around to where my hostel was. I found the ease I wanted and a bed. The courtly nobleman then said, "My lady, you must have repose." Whereon he ordered them to close the hostelry, and this was done. I wakened with the morning sun.

I wore the finest things I could as I was feeling very good. I took with me a heavy spear, and soon a knight came riding near, von Horschendorf, a sturdy man. He challenged me and then began his charge. He wanted to obtain a ring and jousted only for gain. 
I'll tell you briefly, it was so:

I broke ten lances in a row on him, and all he did was miss; he got quite vexed because of this, and when we made the final course he missed once more but struck my horse right in the head. The wound was bad, which made the good man very sad.

I laid my armor all away and dressed in feminine array; I had some lovely clothes to don. Then to Vienna I rode on and eighty nobles, good and strong, in happy spirits went along with costly gear and richly dressed. I heard then many a courtly jest.

When it was known that I was there the ladies started to prepare themselves and many a costly gown was put on ladies of the town. They dressed themselves in rivalry and each was jealous as could be; who came in more elaborate state would win another's lasting hate.

819 So fashioned is a woman's mind: though she be young or old, I find, she likes to have a lot of dresses. It is enough if she possesses the things, they are not just to wear but rather so she can declare, "I could, you know, be better dressed than many who always wear their best."

82I Vienna ladies looked right well when I rode in, I'm glad to tell. The streets were filled, as I rode by, with women, and I won't deny I thought it really quite a treat. I saw there many a lady sweet, and all so warmly welcomed me that I was happy as can be. 
We rode along, and when we neared my lodging place a knight appeared who strove for honor and for fame and I shall tell you now his name:

Sir Hadmar von Kiihnringe. With a band of errant knights from all the land he welcomed me before the inn. "Crash!" and "Crash!" They made a din.

The welcome soon was going strong;

before the inn a surging throng of knights contested on a field. The mighty crash of shield on shield was heard from all about, it's true. Sir Hadmar and his noisy crew received me with their knightly sport. I rode into the hostel's court.

824 There was a balcony that faced them. Here in woman's dress I placed myself. To see me was enough to make the sport get pretty rough. In groups the riders raced around, the field became a battle ground, and some collided rather hard.

The young knights sought to win regard.

825 When I saw horses in the dirt and knew that someone would get hurt I bade my marshal through a squire to ask the riders to retire.

When he told them of my request at once they let the jousting rest. They stopped because they wished to please and rode then to their hostelries.

826 Soon after came the end of day, and all the knights had gone away. I wished my courtly page and sent for him. When he had come we went aside from all the other folk and for an hour or two we spoke. I said, "My messenger so dear, I bid you hearty welcome here. 
"Now you must tell me, courtly youth, and not attempt to hide the truth. How does my lovely lady feel? I wish to know (do not conceal a thing) if she is gay or sad for, if her mood is always glad, I know my plans will never miss.

She's all my joy, I'm sure of this."

829 In answer quickly spoke the boy, "She's feeling well and full of joy. I heard the lady once maintain, whatever happiness you gain will make her really glad at heart. The lady had this to impart, "Whatever honors him will be in every way a joy to me."

"Dear messenger, I ask a boon which you must grant me very soon if it can possibly be done.

Go see again my lovely one and ask her by the worthiness which God permits her to possess to send a gift and her consent to wear it in a tournament."

840 "Lord and friend, I'll hurry there. May God help me in this affair! I'll do the best I can for you. If the lady fair is willing to bestow the present you desire, if I am able to acquire the gift from her, and if she's kind, I'll be right back again, you'll find."

84I "Then go! May God not let you slip. Both there and while you're on the trip may blessings and good fortune lead; I pray this from my heart indeed. If she will send me, as her knight, a gift ' $t$ will be a great delight. May God go with you now to her, my friend and faithful messenger." 
842 The page departed as he said he would. I went to find my bed and there remained until the day had come to drive the night away. I heard an early mass, committing myself to God then, as was fitting. Without Him honor will not last until a half a day is past.

843 When I received a blessing there I left the chapel to prepare myself and see that all was good which I put on, as jousters should who want to guard their bodies well and are determined to excel. I hid the armor to the throat then with a white and folded coat.

848 I left the hostel on my horse and saw my chamberlain von Gors with seven squires, all well arrayed. No clothes could have been better made than those of his and of his men. He took my horse's bridle then and, walking, led it festively. Many a noble rode with me.

849 About me was a surging throng. The balconies there all along were filled with ladies, side by side; their glances made me satisfied. I saw then many a lovely form which made my heart feel gay and warm. To look at ladies is a pleasure, their greetings every knight must treasure.

850 We travelled through the city thus. A hundred nobles came with us, with splendid gear and clothes they rode, each knight a handsome steed betrode, and every piece of metal gleamed. With happy hearts the riders streamed along, and singing as they went. For all it was a gay event. 
And so I rode upon the field. There waited, all prepared to wield a lance, the bishop's governor.

He needed now to wait no more and, as I moved toward him, the knight tied on his helmet, trimmed and bright; his squire then handed him his spear. $\mathrm{He}$ wished to serve his lady here.

856 Von Gors, my chamberlain, had seen and spoke, "My lady, noble queen, here comes the governor toward you. Now take a spear; whate'er you do, sit firmly or you'll come to ill, for he has bravery and skill and is a very sturdy man. He'll surely do the best he can.

With care I followed his command;

he put a spear into my hand. The governor began to dash at me, another was so rash that he raced out in front of him (at this the governor was grim).

Sir Gundacker was the other's name, von Stier, and not unknown to fame.

$858 \quad$ This knight rode at me very fast.

The governor, though he'd been passed, continued on, and I could see both riders rushing down on me. Now was the time to spur my horse to charge with all his speed and force. I missed the first, as I designed, and broke my spear on him behind.

859 Where the helmet meets the shield and the collar is revealed, right on the throat the man was hit so violently the collar split.

The noble almost lost his seat and fell down at the horse's feet. We both, of course, regretted this and wished my joust had been a miss. 
That's how I rode my tourney then. And was I missed by both the men?

No. The knights had jousted well and each one broke his spear, they fell in pieces, so it wasn't bad.

The Knight of Stier was very glad to find that he had earned a ring from Venus with his tourneying.

Soon on the field was such a press that I was angry, I confess.

They crowded here, they crowded there and crowded so that I nowhere could find myself an open space. ' $T$ was hard to joust in such a place. The course I ran could not be long, for this there was too great a throng.

All wished to break a lance on me before they left and often three would charge together, for so great was their desire they couldn't wait. You can believe, when I saw that, I sat as firm as e'er I sat and prayed that God increase my skill and save me from a shameful spill.

I often had to dodge and dash in order to avoid a crash; it took some pretty skilful riding to keep from frequently colliding. The field was full of knightly folk. A lot of lances there were broke for ladies valiantly that day and rings of mail were torn away.

Soon after to the inn we went where five-and-thirty rings were sent, a ring for every gallant knight who'd earned one with his skill and might, who'd broke a spear on me, that I myself had seen the splinters fly. To each of these a golden band was gladly given from my hand. 
I rested well when all had gone. I left the hostel with the dawn and rode to Mistclbach to joust and serve my lady sweet with lust. Many had come to share the sport of which I'll tell you now in short: they broke eleven lances then on me and I broke only ten.

Eleven knights with joy and pride received the rings which I supplied, for they were happy to have earned the prize for which they all had yearned. I stopped off at the inn at last and, just as soon as night was passed, from Mistelbach rode on again with many good and sturdy men.

Two hundred knights were in the crowd that rode with me, and most were proud; one saw it in the gear they had and in that they were richly clad. But I was just as proud as they as I rode gaily on the way to Feldsberg. At the journey's end the host received me as a friend.

Sir Kadolt von Feldsberg was his name; from all this man received acclaim, and rightly for his honesty. The worthy noble rode toward me with forty knights with trappings which looked very fine. Their clothes were rich, well-cut and masterfully made.

It was a splendid cavalcade.

I was welcomed by him there much better than I've been elsewhere at times. He was a courteous knight and asked in language most polite that I should come and be his guest. "The queen must grant me this request and stay with me and eat my bread. No one could want her more," he said. 
I sent word to the honest man and asked that he give up the plan. Were I to stay with anyone, I said, I surely wouldn't shun his house. He shouldn't take offense but I must bear my own expense and only take what I had bought and not a single thing for nought.

He spoke, "Stay with us, lady, do. I'd like to introduce to you some noble ladies, fair and gay, well-bred and nice in every way. They want to see you, that I know, and $I$ intend to use them so that to my suit you will give ear and come, to please the ladies here."

I answered him, "I'd like to see the ladies all if it might be that I may do so and decline to let you care for me and mine. Please tell me what you think of this." The knight was sad that I'd dismiss the invitation he had sent. Then to the hostelry we went.

At once I asked someone to call the knights and to announce to all that I would give each one a chance to earn a lady's loving glance. Many a good man thereupon began to put his armor on. I did so too and soon was decked quite nobly, as one might expect.

The noise resounded all about the town of people coming out. At once we rode into a field to serve the ladies with spear and shield. The service there of some was brief and only brought the knights to grief but other men were glad with gain. The service of ladies brings joy or pain. 
Then on the field appeared a bold and worthy man who, as was told, with knightly deeds and knightly ways had often won both prize and praise wherever nobles came to serve. He did so well as to deserve from ladies thanks in any case; from some he got a fond embrace.

Sir Siegfried Weise, so the knight was called, was one who knew no fright and never had a timid thought:

a good man, he, who feared for nought. Where there was striving for a prize he earned the thanks that none despise. With knightly skill in many a test he won the honor he possessed.

With gilded crest the noble came onto the field to spread his fame. The knight, renowned throughout the land, then took a heavy spear in hand with which he wished to joust. I tied my helmet and was set to ride. We spurred our horses and began the course, I and this famous man.

The charge we ran was very long. Sir Siegfried Weise, who was strong, desired to knock me from my horse; I had the same in mind, of course. But still the joust was ridden well and so that neither of us fell although we brushed while riding fast and broke our shields as we rushed past.

The joust was made so close that we struck shield on shield and knee on knee in riding by each other so.

Both knees were badly bruised, I know, and both the shields were split in two. The splinters from the lances flew and in the collar of this lord as well as mine wide holes were bored. 
The joust with which I broke this one, though it was beautifully done, brought pain and harm. I'll tell you how.

It was a pretty joust, I vow, yet I'd been happy with a miss; now listen, what occurred was this.

I'd taken a heavy weapon from a youthful squire when I saw come Sir Ruprecht von Purstendorf, riding hard; he almost caught me off my guard. I charged him, and my spear tip smote right through his collar to his throat; it passed through shield and mail and all. The knight could not avoid a fall.

He landed far behind his steed. At once his wound began to bleed so that the grass about was red; they thought at first that he was dead. This issue caused me deepest woe. I sadly left the field to go into the hostel. I was filled with grief for him I'd nearly killed.

But he was strong and didn't die. The morning after, just as I was all prepared to ride away, a message asked that I would stay. It came from Sir Kadolt, the host of Feldsberg, who loved honor most. He asked that I would visit there his wife and many a lady fair.

I spoke, "This I shall gladly do for him and for the ladies too. I'll come to him to hear a mass and meet the ladies as we pass." The messenger was happy when I told him this; he hastened then to tell the host that I'd appear, which all the ladies were glad to hear. 
At once the noble donned his best

for me and was with splendor dressed.

I also put some fine clothes on

and rode lightheartedly thereon

up to the castle where I got

a friendly welcome on the spot.

I thanked them warmly at our meeting and gladly heard their cordial greeting.

The host received me as a friend. His wife then started to descend a stairway with the ladies all. Their trains with every step would fall down a stair before my gaze.

Their fair appearance, gentle ways, and, more than these, each lovely glance soon made my heart begin to dance.

I saw them coming toward me thus; to wait would not be courteous so I approached with manner mild but gay, and all the ladies smiled that I should walk so merrily with pretty women's clothes on me and lovely braids down to my hips. I met a lot of laughing lips.

The wife spoke up with spritely mien, "I welcome you, my Lady Queen." I bowed politely as I heard; the others came to add a word. I offered one of them a kiss and she turned rosy red at this; I kissed another standing by who blushed, for she was also shy.

When all the greetings had been said the mistress of the castle led me in a chapel, finely done; at once a service was begun and God was glorified in song. Around me was a female throng and I'll confess, the truth to tell, that God was then not served so well. 
I was almost bound by cords of love and by the tender glances of a pair of shining eyes I saw. That I escaped and could withdraw was due alone to faithfulness. If any woman could suppress my constant loyalty, I swear ' $t$ would be a certain lady there.

Her beauty and her charm broke through my wondering eyes before I knew and fell into my heart. It skips whene'er I think of the rose-red lips which I saw laughing then at me and which had spoken so pleasantly. They would have stolen all my sense were constancy not my defense.

For while I looked with heart aglow my constancy addressed me so, "How can this be? What now? What now? For whom will you renounce your vow to the lady you have loved so long, who's never done you any wrong? Away with this! He who permits such feelings must have lost his wits."

I thus continued, lost in thought and unperceiving. So distraught can those become who fix their mind on women. I was deaf and blind, to all around as much as dead until I heard the Bible read. Another priest began it; then I came back to myself again.

The ladies stood. I wished to bring up to the front my offering and asked the wife to lead the way. She spoke, "Why, what would people say? My manners would be rather mean were I to go before a queen. It wouldn't do my honor good; you must not think I ever would." 
So I went first at her request and soon was followed by the rest.

I walked with such a happy air that one heard laughter here and there.

To go and bow and turn around and then come back took time, I found, moving with a lady's stride, no longer than a hand is wide.

Soon afterwards the mass was o'er and I prepared to leave once more. The host and also his lady sweet invited me to stay and eat. I spoke, "I'd gladly do your will, since you seem to wish this still, but constancy has sworn an oath and so I must refuse you both.

"I've made this journey as I vowed," I said, "and never have allowed a knight or lady yet to give a thing but she for whom I live. She gives me all my happiness and is my comfort in distress, it's she who keeps my spirits high; and, if I serve her, that is why."

I rode back to my hostel then and sent the rings to all the men who'd driven spears against my shield and left the splinters on the field. I counted twenty, this is true, but I myself broke twenty-two good lances there as it befell. It pleased me to have done so well.

While at the inn I quickly ate; and, since I wished to leave in state, I saw that all was in good shape, then donned a new and pretty cape. The dress I wore was also new. At last I asked my retinue to ride in splendor through the town, so they paraded up and down. 

a crossing to Bohemian ground.

A lovely meadow was at hand to which I led my festive band and had some messengers proclaim: who for his lady would win fame should arm himself without delay. I donned my armor right away.

A lot of nobles got the word and came, a hundred, so I heard, in splendid dress. They raised the shout, "Give way, my lord, watch out! Watch out!

Let every gallant knight prepare to honor now his lady fair!" They rode toward me with battle lust; I too was anxious for a joust.

I strained just as a falcon might. Against me rode then many a knight; my wish to serve my lady's pride was fairly soon well-satisfied. Before me many knights were massed who rode against me thick and fast and, through bad manners, often three at once would charge their steeds at me.

964

I'll tell you, there was many a spear and shield and helmet lying here. For all about this meadow land by many a knightly rider's hand shields and helmets were broken through; and here and there one saw a few brave and skillful nobles fall who were not used to that at all.

Before the tourneying was o'er up spoke the bishop's governor, "My noble queen, you need not stay with us but can be on your way. Your journey's ended, well and good, now you can travel where you would. I'll take your horses and your men until you want them back again." 
As he advised I left the place and so as not to leave a trace. But first I gave out rings, nineteen, and went into a wood, unseen, and took my armor off in haste for I had little time to waste. I called my servants then to tell them every one a fond farewell.

With stealth, to carry out my plan I rode off with a single man; one of the governor's was he, the very soul of loyalty.

Von Fronhoven he was, Sir Kol, and well could lead me to my goal, Vienna. Almost every stone and every street to him was known.

The journey there was quickly made; I found an inn in which I stayed three days and nights, but while I hid, just listen well to what I did.

I had them make the battle dress for half-a-hundred steeds, no less; all these were masterfully done and quite expensive, every one.

But while I had these things prepared hear how my loyal servants fared. After I'd left them all behind my steward with his courtly mind took my three horses and my shirts, as well as cloaks and capes and skirts. Soon all the woman's clothes he found upon the horses' backs were bound.

From the meadow he took everything to where some knights were gathering. They hurried quickly toward him then and saw my retinue. But when they didn't see me anywhere and all the clothes that I'd left there upon the horses' backs were seen, they said at once, "Where is the queen? 
"Yes, tell us where! Where has she gone?" Some other knights rode up thereon.

My steward answered them and spoke, "The queen has played an evil joke on me that will bring grief, I fear, for she has gone and left me here and where she is I do not know. This changes all my joy to woe.

"These many articles of dress, these horses add to my distress. She left them here, what shall I do with them? I'd like advice from you. 'T were wrong to take all this away; should I just simply let it stay right here? Now tell me what is best. I'll do whatever you suggest."

The governor said gallantly, "Good youth, it seems the best to me to give the minstrels here with us these things, and not to worry thus; she can get new ones for the old. If she's as rich as we've been told and as one judges by her thrift, she won't be injured by the gift."

My steward answered in this wise, "Lord, it shall be as you advise." He gave the minstrels every bit, just as the governor saw fit.

At once the latter undertook to care for those whom I forsook and, since I'd given my consent, he led them with him when he went.

Right after that the noblemen rode back to Austria again. They left the Thaya soon behind and came to Feldsberg, there to find a good and rightly famous host. If hospitality can boast that it bears honor one should praise Sir Kadolt von Feldsberg all his days. 
The man just would not be denied. He brought the nobles all inside to spend the night with him and dine.

He served good food, and mead and wine were brought as long as they remained; thus till his death he entertained. They were well treated by this knight and rode away with morning light.

Soon they were in Vienna too. I was delighted when I knew for there was nought I wanted more than to have my servants as before. I had the hostel decorated at once, for I was most elated that I should see the nobles there. We had a merry time, I swear.

987 I bade them bring around my horse. I wished the governor, of course, to see me in my altered state. The courtly noble didn't wait and, ere my horse was gotten out to me so I could ride about, before the inn the knight was seen. He spoke to me, "God greet you, queen.

"We see God's wonders," he began, "in you, that you are here a man and were but four short days ago a woman. You have altered so; I'll never understand just how. You were a wealthy queen and now are just another man we've known. To whom did you leave your realm and throne?"

989 The knights and I all laughed a bit as always at such clever wit.

Then those who'd ridden out to me came thronging in the hostelry.

They wished to see who'd been so bold. Then many a tale and joke was told to me. We passed the evening thus; a lot of drinks were brought to us. 
Since I had something to confide I led the governor aside and told him what I planned to do. I said, "I'd be obliged to you if you would help me and consent to wear throughout the tournament my coat of arms. I'll not forget and shall be always in your debt."

Then spoke the high-born nobleman, "I'll help you any way I can, for you need never be afraid that I'll refuse to you my aid. I'll gladly give it to you now and wear your coat of arms, I vow, throughout the tourney on my steed." I thanked him and was pleased indeed.

When he had given me his word and when the other knights had heard that he'd agreed to my request I had no trouble with the rest and just asked those of highest ranks. They all assented and with thanks: the barons, counts, and vassals then until I had my fifty men.

We stayed in Vienna four more days and passed the time in pleasant ways. We saw some women there in truth the sight of whom restores one's youth. Whoever is a gallant knight will feel, I know, his heart beat light to see a lady and to find that she's both beautiful and kind.

On Sunday all were up at dawn and in a hurry to be gone. Inside the city all about were sounds of riders moving out. We rode away as if to war toward Korneuburg. With us we bore a costly banner which was made, I'll tell you how, for this parade. 
The standard had been made with care.

White taffeta it was, a pair

of bars were sewn thereon (a span

in breadth they were and black) which ran

obliquely from the right and down.

My buglers, when we left the town, were blowing as we rode along

some marching music, high and strong.

Behind the banner there was borne the helmet which I'd always worn but now it shone just like a sword, I do not lie, and with a cord of finest silk a fan was bound to it. Thus was the helmet crowned and very prettily, it seemed.

The fan was gold and brightly gleamed.

It all was fashioned with great pains.

To every tip were bound the vanes of peacock feathers, skilfully and as I wanted them to be.

The fan was wrought with many a fold, to each were fastened leaves of gold so that the whole was covered o'er with shining leaflets by the score.

Beside the helmet was my shield. The whitest ermine made the field and over this was sewn in place two sable bars from chief to base. Upon these bars which ran across the field was fixed a costly boss. To hold the shield were heavy bands made up of many silken strands.

1007 I rode to Korneuburg that day decked in the best of knights' array. Before the town the Kühnringe brothers awaited me with many others. It was a very friendly meeting and very courteous was their greeting. The nobles with them were polite and received me as beseems a knight. 
Thereon into the town we rode each noble went to his abode, inviting another whom he knew but who had made arrangements too. I rode into my hostel then; to hostels went the other men where they consumed good food and wine. Soon many a knight was feeling fine.

IOIO

No food was left, no wine was spurned by them, and wax was freely burned, one saw a lot of flaming lights. As often is with merry knights, they wandered here and wandered there around the city everywhere.

Who had no torch, the truth to tell, could see by other torches well.

That evening many nobles came to visit me. I did the same and gladly went to hostelries to see such merry men as these. Thus half the night was squandered though I would not change a thing, I know, for there were lots of friendships made which never after were betrayed.

The other half was spent in bed, but when the eastern sky was red to church we hastened right away. Many a knight had come to pray that God would help him to succeed. One ought to ask God's help indeed; except for God and for his grace none would be happy any place.

When mass was over word was sent to choose sides for the tournament. This soon was done as it should be, and all divided equally. Two-hundred-fifty knights had come because their hearts were venturesome and since it was their ladies' will.

They wished to demonstrate their skill. 
IOIS

1016

1017

IOI 8

1019

Without delay they all began

to arm themselves, each gallant man.

It did not take me long to don

my shoulder armor and put on

that for my legs. How bright they were!

' $T$ was then I saw my messenger.

This pleased me in my inmost heart

but he soon caused me many a smart.

When I beheld him waiting thus

I bade my squires depart from us

and, free of other ears and eyes,

addressed the courier in this wise,

"My messenger, to me so dear,

I offer you a welcome here.

What is the story that you bring and did she send me anything?"

He sighed with sorrow then and said no word but stood with lowered head.

I spoke to him, "How's this? What meant the sigh? What has the lady sent

to me? Why are you acting so?

You've never looked so filled with woe.

My joys are gone and I'm accursed;

your silence makes me fear the worst."

He spoke, "I'll tell you with regret, my lord, what I would fain forget;

't would make me happy, it is true.

The message I'm to bring to you

is so distressing, I am sure,

that if your lifetime should endure

a thousand years you'd still bewail

what you'll discover in my tale.

"Your lady wishes me to state,

for you she feels nought else but hate

and will not see you any more.

She says, you well deserve this for

disloyalty of every kind,

and that she very soon will find

a way to punish what you've done.

She told me this, the virtuous one. 
"She told me why her wrath is such and how you angered her so much. She said, the news was given her as really true that you prefer to serve another lady now, and this was stated as a vow; she knows your lack of constancy. Thus spoke your lady fair to me."

I cried, "Alas, the dreadful pain which I shall always bear in vain within my heart until I die: to choose a lady fair whom I desire and love with faithfulness and have her cause me such distress. I've only grief, my joy has fled; I wish to God that I were dead!

"Or that I never had been born! How did I earn her wrath and scorn and, being constant, lose her favor, with loyalty that would not waver? How could my fortune be so bad! God knows indeed I never had disloyal thoughts and was not peeved whatever treatment I received."

I wept there as a child who fears and I was nearly blind with tears; I wrung my hands the while I wept. My aching heart could not accept this sorrow and with pain was racked. In every joint my members cracked as one breaks sticks to feed a flame. My grief was not a childish game.

While I was weeping, filled with gloom, the governor came in the room and spoke, "What can this be? What's this?" He turned around then to dismiss the page. "Go out," he said quite grim and closed the door right after him.

"Now," spoke the knight so brave and strong, "just tell me who has done you wrong." 
That he should speak so kindly then made all my grief come back again so that my tears flowed as before. I cried, "Alas, forevermore. I sorrow that I cannot say to any why I grieve this way. The cause of all the pain I feel is something I may not reveal."

But when the faithful man had seen and heard my grief and knew how keen the torment was, he sorrowed too and, by my truth, I say to you, soon joined in my lament and cried as if his father dear had died though why he wept he did not know; a strange occurrence but it's so.

I032 And, as I saw him weeping there, within my breast the pain and care once more became so great I bowed my head with woe and cried aloud, "Alas that I have life and breath, may God in mercy give me death! From this sad world would I depart." I longed for death with all my heart.

r033 While we displayed such anguish here who but Sir Heinrich should appear. Von Wasserberg, as he was named, for chivalry was widely famed and was my sister's husband. He exclaimed, "See here, what might this be? And who has ventured to provoke such woe in you?" With wrath he spoke.

"In truth I'd like to hear your tale.

This is a most unknightly wail, for you lament as loud and wild as any orphaned beggar child or any woman who's afraid. Is this the way a knight is made? No. Whatever is amiss you ought to be ashamed of this." 
"Sir Heinrich," said the governor, "Sir Ulrich's suffering is more than I have ever seen or heard but I don't know what has occurred. It's something he will not relate although his trouble is so great it pains me too. I cannot guess what is the cause of such distress."

Sir Heinrich was a forthright man. "Sir Governor," he thus began, you ought to leave us two alone and what it is that makes him groan and weep he'll surely have to share for I shall ever help him bear his sad misfortune faithfully. To aid my friend is joy to me."

I037 The governor soon went away. Sir Heinrich then without delay made sure the door was firmly tied and angrily began to chide, "This isn't how you ought to act. We should be happy, that's a fact, because of all the praise you've won with knightly deeds that you have done."

1039

I spoke and answered thus the knight, "My heart will never more be light, in this you can believe your ears. Were I to live a thousand years I would not cease to sorrow still. Though you may think it good or ill I'll grieve because of what befell but what it was I cannot tell."

He said as soon as I was through, "I know what has befallen you. Listen, I'll tell you what is wrong: the lady you have served so long and faithfully, my worthy lord, to gain a lover's fair reward, who has your service and your vow and promised much to you till now 
I042 her favor has denied at last.

This must be why you're so downcast and why one hears these cries of woe. You must admit that this is so." At once when he said this the blood came from my mouth, in truth a flood out of my nose began to race till it had reddened all my face.

As soon as he beheld me bleed the courtly man cried out indeed, "Dear God, I offer thanks to Thee that Thou permittest me to see before my death a gallant man of whom in very truth I can maintain, he loved without deceit or wavering his lady sweet."

He knelt before me as I bled and raised his hands above his head and thankfully these words confessed, "In seeing it my soul is blessed! I'm grateful just to know of this, it fills my heart with sweetest bliss to make me happy all my days. I'll always think of this with praise."

$\operatorname{105} 2$

Again my sobbing made me weak. I started wretchedly to speak, "I must give up the tournament.

One can not tourney and lament; in knightly games one can't be sad, what one does then will turn out bad. To serve a lady well a knight must joust but do so with delight."

I054 The honor-loving honest man laughed at my statement and began, "All this has been decided on, your armor you will have to don. Though it be joy or more distress you'll get into your battle dress." He put it on me hastily but got no word of thanks from me. 
He placed my helmet on me last, then with his hands he tied it fast and led me out of there with force to where I found, all decked, my horse. I mounted with my grief unhealed, at once he gave to me my shield and so with sorrow and belated I rode to where the others waited.

They waited right before the inn, with shining trappings, to begin.

Their battle dress too gleamed and glowed as to the jousting field we rode.

I saw Sir Hadmar von Kühnringe then surrounded by a troop of men and also saw Sir Heinrich, his brother, who was the center of another.

I057 While helmets onto heads were tied we formed the groups with which we'd ride.

I took a sturdy spear in hand and rode away then from our band. I came forth all alone indeed and then began to spur my steed to race as fast as he could go. I charged Sir Hadmar's forces so.

I058 And when I reached the troop I broke my spear off with a skilful stroke; it shattered well though it was large. I did not slow my rapid charge but rode their spears and shields in two. Sir Hadmar's men did not pursue, for courleously he cried, "Don't stay him now, just let him ride away."

I rode as fast as I could spur back to where my comrades were and spoke, "Let's start the tournament;

I got away by their consent. Were I to splinter thirty spears against them, they, so it appears, would let me keep escaping thus. I think, because they're courteous." 
At once I took another lance.

We saw Sir Hadmar's troop advance

toward us and at a rapid pace.

I turned my men about to face

the strong attack the noble led;

he was both skilled and spirited.

We charged the foe just as one should, riding as closely as we could.

1064

I065

And when the other troop was nigh

I spurred my charger so that I

was moving very swiftly when

I struck the first of Hadmar's men.

On him I broke my spear in two,

plunged in the troop and then crashed through.

My knights all followed after me

and struck them hard and skilfully.

When we broke through his squadron so

Hadmar von Kühnringe wasn't slow

to get his troop in shape once more.

He caught three of my men before

they ever got their horses turned;

he was a master, as they learned.

He knew a lot and was precise

and often gave some good advice.

I066 But we surrounded him and might

have captured Hadmar when a knight

(his brother Heinrich) led a raid

against us, coming to his aid.

Sir Heinrich's troop rode well and fast

and rammed our horses as thcy passed.

One heard their lances loudly crack

and saw them slowly force us back.

1067 As we by focs were ringed about

a squadron came to help us out:

it was Sir Wolfger with his band.

He galloped up with spear in hand.

The valiant knight had taken care

to catch the foe quite unaware;

the charge was carried out with skill,

for Hadmar this meant only ill. 
There were no others who could ride to help; two troops on either side, no more, were in the tournament. The honor-loving nobles spent their strength and lances so that they won glory and renown that day. But it was clearly true that none gained easily the fame he won.

1070

Many a man in these affrays through gallant exploits won high praise. Low-minded nobles were not there to strive; it's like that everywhere. The true knight seeks an honored name to others it is all the same if they have ease and property. The difference isn't hard to see.

"Crash! Bang!" until the day was o'er rode Lengenbach, the governor. Sir Wolfger von Gors was tireless here and on the foe broke many a spear, he never stopped throughout the fight. Sir Dietmar von Liechtenstein, a knight who's always striving to excel, was one who tourneyed very well.

Sir Heinrich von Wasserberg had done that day as much as anyone; von Kiowe, who was very stout, was praised by everyone about; Sir Ulrich von Steutz displayed such skill that people talk about it still; and what the knight, von Ottenstein, did to the enemy was fine.

Sir Engelschalk used many a lance and risked his honor on pure chance; this Lord of Königsbrunnen threw it often on the scales, it's true, one owes him praise for recklessness. Von Rebstock strove and with success for fame and his desire was such, he thought no labor was too much. 
Were I to name you all the men whose exploits were outstanding then, who strove and honor there would find, and name all those of gallant mind, and tell how one crashed through the foe, how that man's lance was splintered so, how he was bold, and he was strong, you'd think my story much too long.

1075

You've heard a lot of tourneying so I'll not add a single thing to what I've told except to say that I used up nine spears that day. In brief, it's this I want to tell, that all the sturdy knights did well and each man strove with every limb; these sought to gain renown for him.

1076

The darkness stopped the tournament and from the field at last we went back to the inns with manly pride. I rode to mine and found inside the knights I'd taken prisoner. I let them go just as they were, without a loss, through courtesy. They all expressed their thanks to me.

I077 In Korneuburg we spent the night, and with the early morning light all travelled home with spirits high. I rode from there with many a sigh. When he beheld my lowered head the loyal messenger then said, "It causes me much pain and woe when I must see you sorrow so."

1078 I spoke to him, "Dear friend, now say, how could my heart again be gay, how could I hope for happiness? My lady grants me no success, which means that I shall never more be happy-hearted as before. My joyful spirit now is gone and I can only sorrow on." 
The youth replied, "Lord, I believe that it will do no good to grieve; do not despair of pleasure now. Of course, I cannot tell you how your lady actually may feel; it's possible her wrath is real but maybe it's a test for you. These are things that women do.

1080

"I'd like to recommend a plan with which I'll help you all I can: why don't I see if I can find if she's unfavorably inclined or whether this is just a test. Before I'll see you so distressed I'll try it once again indeed. God grant my efforts may succeed."

"Page, you've never failed me yet and I'll be always in your debt. I say, the plan you recommend is one which pleases me no end. It's really more than I dared ask but you yourself assume the task of helping me. May God confer rich blessings on you, messenger."

The messenger departed then and I rode onward, sad again, until at last I came to where I found a lot of loving care, to my sweet wife. She couldn't be in any way more dear to me although I'm in the service of another, who's my lady love.

I090 But hear what happened to the squire: he needs what help he can acquire from luck and from a gracious fate. When he arrived at her estate she laughed because he looked so grim but welcomed and then questioned him, "Now tell me what your lord has done. Say, am I still his chosen one?" 
"Yes, lady, though you be unkind to him he has so fixed his mind that no one else can be so dear, not even life itself, I fear.

He loves you more than any thing and serves you with no wavering. I'll take an oath and swear to this by all my hope of heaven's bliss."

I097

She spoke, "I grant him my esteem and tell you truly, though I seem to show disfavor, it's not so; but this is what you need to know: that which he wishes in return for service he can never earn. He should not think this hate or spite, the same is true of any knight.

"Ride to your master now and say what I told you. If there's a way I'd like to meet him secretly, could it be managed so that he might take such care and not expose us when he comes and when he goes that none will know the guest I've had. If this can be then I'll be glad.

"My counsel, since he's venturesome, is this: as lepers you must come on Sunday morning (don't be late) and join the lepers by the gate. You'll knock as soon as you arrive and very shortly I'll contrive to send a maid; what she directs, so do it that no one suspects.

"You must tell him another thing: he should not come here wondering if I shall let him in my bed; he must not be so far misled. That I'll be glad to see him here does not mean (you must make this clear) that he will gain the love he's sought. This prospect isn't worth a thought. 
"I only let him come to me because you've often said that he has served me well his lifetime through. Now mark what I shall say to you. I want him as a secret guest so I can make this one request: that he will let this service end. I ask this truly as a friend."

"I'll tell him, lady, your desire and know he'll do as you require. He'll come as quickly as he can: this news will make a happy man. My lord will surely not decline but come at once, as you design, in clothing like the lepers wearjust as you wish him, he'll be there."

The messenger departed then and rode to where I just had been; since I'd already left the place he followed at a hurried pace. He galloped onward night and day and seldom rested on the way; he proved himself a friend of mine. $\mathrm{He}$ found me there at Liechtenstein.

I IO9

The moment that I saw him ride so hastily toward me I cried with joy, "Here comes the page at last; now I'll no longer be downcast. Perhaps he has good news to tell (no other does it near so well) and it may be that he'll impart that which will ease my aching heart."

I rode to him -I couldn't wait but had to hear what he'd relateand said, "You're welcome, messenger, and more so than you ever were. I must admit in very truth, I'm really glad to see you, youth. I hope to God that you'll report good tidings from the lady's court." 
"The lady wishes me to say, she'd like to see you right away but you must meet her secretly. On Sunday it's supposed to be and early, ere the sun is high. Before the gate some ruins lie and you're to come there in disguisethus says your lady sweet and wise.

"You must appear in ragged dress such as a leper might possess and what her courier may direct, that carry out; be circumspect so no one guesses you're a knight. Thus speaks the lady fair and bright: if you are smart there'll be no shame for you, and she will get no blame.

"And you should know what else she said: you must not come if you're misled; no matter how you beg or sigh she's never going to let you lie with her. That simply may not be but just the same she'd like to see you. She'd enjoy a friendly chat. The charming lady told me that."

"I must get ready for the ride and hope that God is on my side. I'll see if I can make it there; the days are long, the weather's fair, one travels far from sun to sun. I think perhaps it can be done and I can get there when she wanted. At least my spirit is undaunted.

"We'll take with us a single groom, a man who's capable, on whom I can depend, who'll not discuss the trip. There'll be just three of us. Six horses, known for strength and speed, shall go along. If there is need I'll race them till they all are dead, to be there Sunday, as she said." 
The Adventure of How Sir Ulrich Came as a Leper to His Lady and of How He Saw Her

I 24 'T was Friday night so we stayed on but Saturday morning, just at dawn, we three set out to make the trip. I took great care that none let slip where we were travelling or why and was resolved to show that I could manage so that not a soul might ever guess the journey's goal.

II25 On my knightly word I vow I rode that Saturday somehow one-hundred-sixty miles and more. When that day's trip at last was o'er I was so tired. Along the way I lost two horses, dead they lay beside the road. I dared not wait and did not think their loss too great.

I 126 ' $T$ was in the town where we arrived so late that night that I contrived to get some clothing, poor and torn, and beggar's bowls. On Sunday morn we donned the rags with many a curse, they couldn't possibly be worse. Instead of swords we took some knives, which we might need to save our lives.

I127 On Sunday morning early we rode eight miles further. Carefully I hid the groom and horses, then the page and I went on again for seven miles until we stood before a castle. There the good and gracious lady chiefly dwelt. I cannot tell you how I felt. 
We walked up closer till we found some wretched people all around who showed their poverty and need. There were a lot, I think, indeed full thirty lepers. Most of these had suffered much from their disease and some of those I saw with dread were very sick and nearly dead.

II 29

I had to go to them and sit (I didn't care for this a bit and did it at my friend's command) as if I were too weak to stand. They greeted us, the sickly group, with many a gasping cough and whoop, and so diseased I could not bear to look, but still I joined them there.

II30 While we were seated they began to ask us questions, every man desired to know from whence we'd come. I found this query troublesome. I spoke, "We come from no place near, we both are total strangers here and want has brought us to this spot to see if they are kind or not."

I 3 I One said to us, "You couldn't pick a better time; the lady's sick who is the mistress of the place, and so they purchase heaven's grace by bringing us the food we crave. Before you came a maiden gave us bread and even wine. For this I pray she gains eternal bliss."

I 33 Then, going from the lepers, we approached a little balcony, before which hung a heavy shade; of costly fabric this was made. They often hang such curtains to keep light and wind from coming through. This one was sturdy and was fast; through it no breezes ever passed. 
I 34 I took my bowl out (in the light it looked a bit too clean and bright) and knocked with it so loud that all could hear who then were in the hall. As soon as I had knocked I stood and begged as loudly as I could that I might get a piece of bread, for many days I'd not been fed.

A maiden, when she heard my plea, looked down at once from the balcony to find out who had made the fuss and saw there were just two of us. She quickly closed the shade and went to tell her lady of my lament and that below were two strange men. The lady sent her to us then.

I138 She came up close and spoke quite low to us, "You two must let me know just who and what you are; now say! I must find out and right away for I'm supposed to only pause a moment. Did you come because my noble lady sent for you? Make sure that what you tell is true."

II39 I spoke thus to the pretty maid, "My lady, you shall be obeyed. For I am here at her command; know this, that I am he whose hand has always been at her employ, and I am he whose only joy may come from her. She can depend on me to serve her till the end."

I14I "The lady waits for my return. I'll go to her and she shall learn that you are here because she sent for you. With that she'll be content. I'll quickly come back here again and give instructions to you then of what she wants of you today." With that the maiden went away 
to find at once the lady fair and let her know that I was there. She told her all and did not hide a thing. The lady thus replied, "I'm very pleased indeed to hear of his arrival. Go, my dear, and tell him what I said, in sum, that I am glad that he has come.

I 44

"He must return this evening. I shall send a message telling why I bade him come, and he shall find just what it is I have in mind. He'll then know everything he should. But you must take him something good to eat: some chicken, bread, and wine; give him God's greeting too, and mine."

The maiden, when she knew her will, returned and found me waiting still. She and another girl now bore what she'd been told to bring and more. When I saw she had company, I set my bowl some yards from me and spoke, "My lady, fill it quick and go for I am very sick."

At that the second maid stopped dead but she I knew came near and said, "I'll take whatever fate decrees and not be scared by your disease. My worthy lady sends to you a welcome and God's greeting too. She says, she'll gladly see the one who serves her, when this can be done.

II48 "Go now, and when the sun has set come back up here and I shall let you hear whatever she may tell to me. I know she likes you well. Of this at least you can be sure, that of a truth my lady pure such favor ne'er before has shown." And then she left me there alone. 
I carried off, when she had gone, the food and drink to pass it on to lepers who were waiting there. I spoke, "I've got enough to share with you. May God this lady bless with many years of happiness. She's given more than I shall need; I'll gladly share with you indeed."

We all sat down to form a ring and placed inside it everything that had been given by the maid. The hands I saw were so decayed they looked-I dare not tell you how; it's more than manners will allow. Upon my honor, I contend, my hair in horror stood on end.

A foul disease was there disclosed. Some fingers were as decomposed, the flesh and bones as foul and rotten as those of bodies long forgotten and buried for a hundred days. It's true, and not an idle phrase: no dog could have such evil breath; already they belonged to death.

I 53 And with these sick I had to eat. How much I wanted to retreat and never share with them a meal but I was forced to stay, conceal my dread, and carefully preserve the name of her I wished to serve, for if I had refused to stay they would have wondered right away.

I 60 To pass the time I walked to town and begged until the sun went down and lit the mountain with its glow. ' $\mathrm{T}$ was nearly evening, time to go back to the castle gate once more. I took my place there as before among the others. Cordially the many lepers greeted me. 
When I'd been sitting there a while the maiden came and led a file of servants bearing food and wine. There was enough for all to dine. She spoke to me, "You must arise and go. Now do as I advise.

Be back again with morning light and take especial care tonight."

I spoke, "Why did my lady dear command my strange existence here if I am not to talk with her?" The maiden spoke, "This can't occur before tomorrow night. Her plan is this: to see you when she can and certainly before you're gone. Just see that no one catches on."

I hurried from the castle ground into a distant field. I found some grain there, growing thick and high, in which we hid from every eye (the messenger was there as well). The field of grain was our hotel and, I assure you, it was bad.

That was a dreary night we had.

I 167 For just as soon as day was done and when the night had scarce begun a stormy wind swept o'er the grain and brought with it a driving rain. ' $T$ was most unpleasant in the field, against the rain my only shield a shabby robe and scanty cloak: as shelter both were just a joke.

I 68 From wet and cold I almost died, but I had other ills beside.

Although I should leave something out I really ought not talk aboutthe unnamed insects caused me grief the whole night long without relief, they didn't give me any rest.

That night I boarded many a guest. 
A night like this I'd never spent and, had I not such fond intent that night to help me to endure all this, I would have died, I'm sure.

Good thoughts we can't have too much of and better yet are thoughts of love. Who has these with him in distress will get much help from happiness.

II7I The morning sun came up at last. Then through the fields I quickly passed and stood before the castle gate. I knocked thereon and asked with great concern if I perhaps could get some clothes, since all I had were wet and I was cold. I begged for aid; once more I saw the pretty maid.

I 72 A lot of food and drink she brought. "My lady wishes," so I thought, "that I get sick and perish here." At once the maiden hurried near and said, "Last night I wondered whether you'd found a shelter from the weather. You look as though you'd had no bed, nor even roof above your head."

I 173 I said, "I've suffered misery.

The cold was most the death of me, and other things tormented us that I should really not discuss. But this and even more I'll bear and I'll be paid for it whene'er the lady takes me as her knight. I live in hope of such delight."

1174 She spoke, "Sit down and eat your fill, then leave the castle and the hill, return this evening when you're due. Upon my word I promise you my worthy lady will not let you wait much longer, cold and wet, for you are soon to come to her. Tonight this meeting shall occur." 
When she said this to me we parted, her words had made me happy-hearted. I hurried to the lepers then, I had to eat with them again but this I did with great distaste, and afterwards I went in haste down to a forest where I heard the songs of many a little bird.

I sat in the forest down below till evening and 't was time to go. I then got up and almost ran in happy temper like a man whose heart with love is all afire and thinks she'll grant him his desire; of course his spirits would be high. In such a fancy there went I.

I left the forest to ascend the hill when day was at an end, driven away by dismal night with all its dark, mysterious might. I climbed down in the moat a ways and hid myself from people's gaze with many stones. As I recall, it really took no time at all.

I 88 So too the page had hidden him; we didn't dare to move a limb. While we lay covered on the ground the warden made his nightly round. $\mathrm{He}$ searched the castle in and out to see no strangers were about and that no one was hiding there. He carefully looked everywhere.

I 89 While he displayed such energy, just hear what happend next to me. That rascal bade his comrades stay and walked right straight to where I lay; he came as close as he could get and pissed till I was soaking wet. I couldn't move or do a thing a quite uncommon happening. 
With this he went in through the gate while there I lay in this sad state and suffered both distress and shame. Out from the balcony there came a light. I climbed up from the moat and quickly doffed the beggar's coat which I had worn as a disguise and hid it from the watchman's eyes.

I stole to the balcony and found a loop of bedding, tightly bound. At once I stepped into the band, my comrade lent a helping hand as from below he gave a shove; my spirit hastened to my love while tender hands drew up the sheet, and so I rose-for several feet.

It happened thus: as soon as I was lifted from the ground so high that my companion could bestow no more assistance from below, the ladies found they couldn't haul me up. I dangled by the wall, annoyed that they should pull in vain. This also caused the ladies pain.

They let me down to rest and then they quickly pulled me up again, right to the place I was before. They couldn't move me anymore, not upward, by a single hair. By all my courtliness I swear both they and I were in distress. Three times they tried without success

The third time down I knew indeed this method never would succeed. I left the bedding in a rage and hurriedly addressed the page. I spoke, "Good friend, I'm sure you are less heavy than I am by far.

Step in, we'll find out if they can lift up a smaller, lighter man." 
II95

I 196

I 197

I 198

As soon as he was seated therc I lifted him into the air, the ladies pulled him up with ease, and I was happy as you please.

He came into their room like this and then was greeted with a kiss. My aunt mistook the page for me; she was embarrassed as could be.

He saw that he'd been kissed instead of me and did not lose his head, but quickly let the bedding fall; 't was this I wanted most of all. It surely wasn't long until I sat therein with all good will. My spirit stoutly pulled with those above as steadily I rose.

This time I reached with no more slips the balcony. My aunt's red lips were pressed with tenderness on mine. The charming lady made a sign for me to follow, and we went into a room and there she lent to me a robe of baldaquin that I could see my lady in.

Therewith I entered thus belated the room in which my lady waited; she sat upon a rich divan.

The sweet and lovely one began with greatest courtesy to greet me while I yet approached her seat. She bade me welcome to the place. I answered, "Lady, grant me grace."

Let me describe how she was clad. A snow-white blouse the lady had put on-'t was delicate and neatand over this my lovely sweet displayed a scarlet garment such that one could never praise too much: all trimmed in ermine; till that night I never saw a fur so white. 
The lady sat in front of me and I am sure I'll never see a lovelier beneath the sun. I knelt before the charming one and spoke, "My lady, by your truth, by your celebrated youth, by your pure and noble mind, I pray, be good to me and kind.

"Lady, you're my chief delight, may I be favored in your sight, may your compassion take my part. Consider the longing of my heart which constant love for you inspired. Consider that I have not desired a thing more beautiful than you, a lovelier I never knew.

"You're dearer far than all that I have ever seen. If I could lie with you tonight then I'd possess all that I've dreamed of happiness. My life will gain by your assent a lofty spirit and content more and more until it ends. It's you on whom my joy depends."

Then spoke the lady sweet and kind, "It never should have crossed your mind that I would let you lie with me. You should not come with such a plea, nor let a prayer like this be heard, for I shall tell you on my word and truly that you will not sway me-now-no matter what you say.

"Your many valiant deeds have brought to you such fame a woman ought to grant you gladly this request; and, could I do as you suggest, I would. But still you should be proud and honored that I have allowed you in my room. This is a lot and more than any other got. 
"You see, my husband and my lord would never want me to reward another so or give my love.

Were I not checked by God above or by my honor, he would guard me closely though this would be hard. Indeed a watch would be in vain had I not honor to maintain.

"My pure intent does him more good than any watching ever would. That I should risk my honor still and also risk my lord's good will is only done to honor you.

And, if some people ever knew of this, my honor would disappear. You owe me thanks that you are here."

"I thank you. I am in your debt and, lady, I shall ne'er forget what you have done and do for me. For I've no doubt your sympathy will cause you, blessed lady fair, to drive away my pain and care by granting me tonight love's bliss, right here and now. I'm sure of this."

She spoke to me, "If what you prize is my esteem, it's most unwise to ask for what could harm my name although I tell you, what you claim can simply not be granted now. If you persist you'll lose, I vow, what favor you have won. It's so." I got up startled by this blow

and quickly went to where I'd seen my aunt and asked, "What can this mean? If $I$ have come up here in vain I haven't won a thing but pain. I can't believe her so unkind; it must not be what she designed for she's not acting as she ought. The lady has to give this thought." 
My aunt spoke up, "It's what she meant; I know for sure, her sole intent was what she said and nothing more, that's all you were invited for.

There's something else which I should say: she had so many of us stay in case you thought of using force, to which men sometimes have recourse.

"I know it's true and must declare, if you so much as touch a hair against her will she'll not receive you ever after (this believe), and even should you not succeed. One thing I've heard her say indeed: if in her service you'll not waver she yet may grant to you this favor."

"I'll not contend with her a bit against her will but, I admit, it's just because I know those here would very quickly interfere. If there weren't such a lot of you I'd wrestle her. When we were through she'd grant the prize of victory. I'll tell you, this is what would be."

"Nephew, hear me and obey. I know she likes you anyway; just do now as she wants, and I am rather sure that you will lie with her quite soon. For you will find the lady really is so kind and is so very feminine that pretty soon you're bound to win."

I went back to the lady sweet and said, "Dear lady, I entreat you by the grace and loveliness which through God's mercy you possess, do not permit that we should part like this. They praise your tender heart: reveal it here to me, and so that I may be happy ere I go. 
"Mistress, greatest joy I know, mistress, you my pleasure's glow, mistress of my heart and soul. mistress of my every goal. mistress over every stone I have and all I'll ever own, mistress, only you can give content, for you alone I live.

"You it is who must preserve my happiness. It's you I'll serve with faithfulness until the last. And should a thousand years go past my service always would endure, my loyalty would be as sure.

That's why you ought to grant me bliss in tenderness. I ask for this."

Then spoke the lady pure and fair, "I cannot listen to your prayer. If I had planned to make love now I'm smart enough to find somehow a way to meet you privately.

Now listen to this word from me: if you continue thus to prate you're really going to win my hate.

1237 "I've told you twice; you can depend on this, that I do not intend to give you love, not right away. Were you as smart as people say, and if you valued my good will, you'd surely keep such wishes still through which from me you'll never gain a thing, and which can bring you pain."

I239 Unhappily I stood up then; I went to see my aunt again and, when I found her, spoke dismayed, "Aunt, once more I need your aid and honest counsel for," I said, "you know, I'd rather far be dead than have her favor thus denied and go away unsatisfied. 
"I'm very sure that if I choose to stay till morning I shall lose at once and certainly my life, but yet with me the worthy wife will have her good repute to mournI would have better not been born. She needs to give the matter thought for I shall never leave for nought."

Then said my aunt, "I'd better go at once and let the lady know that you have said you're going to wait right here, regardless of your fate, and don't expect to change your mind, and that, if she is not resigned to losing honor, she must fear, for you intend to perish here."

I245 My aunt then left me standing there and went to find my lady fair. She spoke, "See, lady, what you get, my nephew Ulrich's so upset that he won't leave the place, it's true, till he gets what he wants from you. Now see, my lady, that you act so that your honor stays intact."

The lady fair and virtuous then said, "It's bad for both of us; you're right, for me as well as him. Though he not fear for life and limb he should be careful just the same and not endanger my good name. This certainly he should defend and leave here quickly as a friend.

"You must go back to him and say, he doesn't need to act this way, that he may well be light at heart. If he'll obey me and depart he has my word that I'll fulfill his hopes and later do his will. If he'll act now as I suggest I'll gladly grant him his request. 
"Now tell him, had he acted right and had he done my will tonight there'd be no reason to complain, he'd not have had his trip in vain for I'd have quickly given in. But, if he thinks that he can win my love like this and can compel assent, then he's not thinking well."

My aunt then left her and returned to where I waited, still concerned. She said, "At last you can be merry and all your sorrows you can bury. Your worries are quite needless for no lady ever offered more than she will give if you'll agree to follow her guidance willingly.

I253 "Dear nephew, you must be content and not get in an argument for, if you don't do what she said, then truly all your hopes are dead and you'll have nothing but regret. Woo her gently and you'll yet enjoy her love before you go. The gracious lady told me so."

I254 While she was talking with me thus my charming lady came to us and spoke to me just like a queen, "God knows that I have never seen a man who has so little sense. You'll sooner drive my favor hence than be successful in your suit by this quarrelsome dispute.

I260 "If, when you came, I'd greeted you," the lady said, "as lovers do then I would never let you go away from here while feeling so. Obey me now, it's for the best, and do for once as I request. Get back again into the sheet, I'll let you down for several feet 
"then pull you up without delay and greet you in another way. When I've received you, not until, then I'll be subject to your will, whatever you may want with me. I've chosen you, as you will see, of all the knights both far and near," thus spoke the lady fair and dear.

"Were I but sure of that, I would do quickly what you say I should but my offense makes me afraid. I fear that it may be repaid in that you'll let me down and then will never pull me up again.

My spirit would be so forlorn that I were better never born."

The lady spoke, "If you demand security just hold my hand, I'll let you do it if I must. Perhaps you're not a man to trust since you don't trust me from your sight although I chose you as my knight above all others whom I knew. As I'm a woman, this is true."

"I shall, my lovely lady fair, put soul and body in your care and at your mercy, as is fit. Though good or ill may come of it I'll do whatever you propose.

Because you told me that you chose me as your lover I shall bless and gladly trust your tenderness."

I265 She said then, "This will serve you well. If you will do now as I tell you to I'll give my promise here: You needn't have the slightest fear; I'll do your will, whate'er it be, and you at last may lie with me. Your wants shall all be satisfied." Thus spoke the lady by my side. 
The fair one took my hand and we went over to the balcony and found the bedding on the floor. She told me to get in once more and said, "Don't have the slightest fear; I gladly give my promise here: you won't leave now, it's not the end. I've chosen you to be my friend."

Though worried, I then took my seat inside the tightly knotted sheet. They let me down a little ways to where they were supposed to raise me up. My sweet continued slyly, "God knows, I never thought so highly of any noble in the land as of the knight who holds my hand.

"My friend," she spoke, "be welcome so. We both are freed from care and woe and I can now invite you in." While speaking thus, she raised my chin and said, "Dear one, give me a kiss." I was so overjoyed with this I let her hand go free and I quite soon had cause to grieve thereby.

I kissed her then as I was bid and let her hand loose as I did; so very swift was my descent that, had not God in mercy lent protection, there can be no doubt, I surely would have tumbled out, but I came down without a fall.

They pulled the sheets back up the wall.

I270 I sat right down in great despair.

The grief was more than I could bear and reason fled in my distress;

I was so mad and comfortless

I cried aloud in bitter pain, "Alas, alas, and all in vain! Alas, that I was ever born my hopes and honor thus to mourn!" 
I sprang up then so overwrought that I had neither sense nor thought and raced unthinking down a steep incline to water which was deep to drown myself in that dark lake, which would have been a bad mistake. My comrade followed hastily else it had been the end of me.

I272 They'd quickly lowered him down too. When he, so courteous and true, heard how I cried at being spurned my loyal friend was quite concerned. He stayed close by me through it all; when I was just about to fall into the water, deep and black, he grasped my arm and held me back.

He cried out, "What do you intend to do, my master and my friend? It's terrible that you should try to jump into this lake and die. You'd lose both soul and body then and had much better never been. Why you're a man who's strong and brave; is this the way you should behave?"

"It has to be this way," I said, "and truly I shall soon be dead for here shall I give up my life since I have lost the lovely wife and that because of my own fault. So it's myself I shall assault and seek this so ignoble death. In truth, I want no life or breath.

"How sadly I have been deceived by this sweet lady, I believed! She said, I should have faith in her, that such a thing would not occur, and then she let me hold her pale and tender hand as precious bail. She got it back through plain deceit, 't was not a very honest feat." 
My comrade's voice was full of cheer:

"My lord, this you'll be glad to hear

(I'll tell you truly, as is right) -

she wants you back tomorrow night.

The charming lady, you will find,

will then be loving and so kind

that you will get your will with ease

and do with her just as you please.

I 279

"But here you can no longer stay, we must be quickly on our way, the dawn has come, it's getting late and it is dangerous to wait.

We need to leave here while we can and see if your young, foolish man is with the horses, as expected, or whether he has been detected.

I 280

"I truly fear that we were wrong in leaving him alone so long for anyone who sees him there will also soon be quite aware those horses must belong to you, and think what damage that can do. Unless the horses stay concealed the whole affair will be revealed."

I282 I spoke, "What you have said is wise and I shall do as you advise, this thought has also come to me; we ought to go at once and see. And, if we have the horses still, then we can come again, and will, to find out whether she will let me back into her chambers yet."

1283 Without delay we hastened then to where the horses once had been.

We found them there and with the boy who greeted me with honest joy and said, "My Lord, I cannot tell how glad I am to see you well. I've suffered so from fear and dread; I was afraid that you were dead." 
Quickly spoke the courtly youth,

"Sir, you will have to know the truth.

I dare not hazard more delay

and need to tell you right away

what is the lady's real intent.

But promise first that you repent this morning's madness, as you should;

the news is really pretty good."

I said, "My friend, you'd best relate the truth to me and simply state the message you were told to bring; for God's sake, don't conceal a thing, just tell me what it was you heard. Don' $t$ be afraid, I give my word that I shall not fall prey once more to madness, as I did before."

"This is the message she conveys through me to you: in twenty days from now she wants you to return. Hear this, you need have no concern, the lady will receive you so that you'll be happy when you go. The beautiful and worthy wife will make you happy then for life.

I289 "That which occurred to you just now she had no choice but to allowI got this from your lady fair.

Among the women who were there . . . . [line missing]

You must believe she had to let this wretched incident occur; 't would not have happened but for her.

"That woman soon will travel on and they'll be happy when she's gone. Then you're supposed to come back here (your lady made this very clear). Ten days she wishes you to dwell with her, and it's the truth I tell. This time she'll really treat you right, as a lady ought to treat her knight." 
With this, I mounted up and rode to Liechtenstein, for there abode my retinue. They greeted me with joy. I thanked them readily. They said, "We're glad your trip is done and glad to see you, every one. Where you had gone, we could not learn and we are pleased at your return."

I 293

I thanked them for the joy expressed and sought a room where I could rest. I stayed three days, then led my band toward Austria, and in this land. For at St. Pölten had been set a tournament. I wished to get there with my half-a-dozen men. The messenger rode with me then.

And as I passed along the road my pain became a heavy load. I spoke thus to the messenger, "If you should want to prove you were my friend I'd like to have you ride no longer with us by my side but to my lady kind and true. I ask this favor now of you.

"Find out for me just how she fecls and everything her mind reveals: if she's an enemy or friend, if she has plans to recommend, how I'm to come there in disguisc and hide myself from curious eyes. Find out these things and what's her mood. I'll owe you deepest gratitude."

I296 "I'll go again since it's your will; God grant that I not serve you ill and that I find her well-inclined. I'll gladly tell you what's her mind, if she has blame for you or praise; I should be back in several days. Be gallant in the tournament for she'll discover how it went." 
He quickly rode from me to where he found my lady sweet and fair.

She saw him and addressed him thus, "I'm glad to have you here with us. Now tell me honestly, good youth, and see you don't conceal the truth, how is your master making out and what did you come to talk about?"

1298

"My lady," he replied, "I know, if you'd be kind enough to show him favor he'd not feel so badly. God knows, you treat him pretty sadly (since I'm to tell what's true and right), for I have never seen a knight who ever loved a woman more than he loves, though his heart is sore.

I299 'I'll tell what happened here to him and how from woe his mind grew dim. Right after he had left this hall, while I was lowered down the wall suddenly I heard him cry, 'Alas! Alas!' As soon as I got down I ran to him; his pain had made the man go quite insane.

I300 "It was a most distressing thing for he was just about to spring into the water. Were my wit not sharp enough to hinder it, he would have drowned before my eyes;

- I stopped him with some hurried lies. I gave him cheerful news from you which brought him to himself anew.

I302 "I counselled him to go and see where groom and horses then might be; we found them all where they had been. As we came back to them again I told him more things you had said, whatever came into my head. I told him you had made it clear, in twenty days he must be here. 
"I also told him that you bade me let him know your heart was sad since you had made him go away. I said, you couldn't let him stay for fear a lady here might tell the one you didn't know so well; because of her you must be on your guard, but she would soon be gone.

1304

"Thus did I lie to him of you, I didn't know what else to do because I feared that in despair he might do something foolish there which he could never more recall. But I must tell you once for all: if you continue so unkind to him, he soon may change his mind.

"I must return to him and say what you intend without delay. For at St. Pölten he will be, where he will serve you gallantly. They have arranged a tournament and, in your service, he too went to prove he can be knightly still and honor you with strength and skill."

The good one spoke, "He should not carry so sad a look for were he merry he'd have more luck. I may be dumb but still I know what's wearisome. No knight who has a mournful face will ever win a lady's grace.

Whene'er a woman is sad at heart because of love, you've not been smart.

"What happened here made quite a show when he forgot his manners so that he should piteously cry out 'Alas! Alas!' and really shout till he was heard. The watchman went down quickly from the battlement and through the castle halls to tell that he had heard the devil yell. 
"They had to ask him when and where. He spoke, 'See, by the wall down there I heard the devil loudly roar, "Alas! Alas! Forever more."

The way he bounded to the lake was quite enough to make me quake but then I almost died of fright when his companion came in sight.'

"And everywhere the watchman said, 'You should have seen the way he fled.

$\mathrm{He}$ almost tore the rocks along, I can't imagine what was wrong. I prayed that God would guard me well and bade the devil go to hell. I ne'er before was so aghast and never ever prayed so fast.'

"Would you have ever thought your brave and valiant knight would so behave? Who lets his knighthood count so small is really not a man at all.

How could this worthy knight go wailing just like a woman who is ailing; and, if he had been recognized, from that time on he'd been despised."

The courier answered, "I admit, he had a painful time of it.

So clouded was his reasoning that life itself meant not a thing. He'd be already in his grave had I not managed then to save him with reports that I contrived, without which he'd have not survived.

I3I3 "I've never seen a love so strong and never known a knight to long so urgently as he for you;

you can be sure that this is true. I know that he's of such a mind that, if you are not soon more kind, he well may sicken in his prime and pass away before his time." 
"Messenger, when you return, pray tell your lord, if he would earn my love then he must take for me a journey far across the sea. If God will bring him back again I promise you that I will then reward this knight so lovingly he'll have great joy because of me.

1316

"I'll give myself as his reward; no woman ever gave her lord or knight in truth a better pay than he'll receive. Now you must say: when he returns from this crusade as wages he'll at once be paid with me, and nothing shall he lackand, after all, he may come back."

"I'll let him know of your request and I am sure he'll not protest. He's told me often heretofore that he could ask for nothing more than that you'd give him deeds to dare; of this I'm sure you werc aware. He'll scrve you now as in the past and faithfully while life shall last."

I318 The page then left and went straight on to Wasserberg where I had gone after the tournament was through. A lot of spears were broke in two in honor of many a lady fair by the noble knights who gathered there. And quite a few of those who came won by their valor lasting fame.

I319 The messenger found me where I sat with other men. To have a chat we went where no one else was near. I spoke, "Now you must let me hear all that my lady fair commands and what to hope for at her hands. If she will grant me what is right my heart will once again be light." 
He spoke, "I'll tell you what I heard.

The noble lady sends you word that you have never earned the prize of love with deeds of any size.

She wants that you go journeying to honor her. If God should bring you safely through the pilgrimage you'll get whate'er you want as wage.

"The lady wishes you to fare across the sea. In truth, I swear, if you will do her will, she said, the trip will stand you in good stead. Indeed she promises to give herself as long as she may live, and what belongs to her alone you can dispose of as your own."

I said, "Her wish shall be fulfilled and all besides she may have willed. There is no obstacle which I can't overcome and I shall die or earn myself a lover's pay, and this in such a knightly way that she at last in charity will grant a woman's love to me.

"I'll do whatever she may ask, be it a great or little task. How glad I am that she's employed me as her knight! I'm overjoyed! There is no trip so long or hard I would not take for her regard and nothing else I wouldn't do. All that I've said, my friend, is true."

I324 He spoke, "I don't like this at all. You know, of course, there will befall you often pain and misery.

If you should sail across the sea it well may be your death indeed and then might come the greatest need: that you'd lose out on paradise, which would be much too great a price. 
"No man should make a pilgrimage

to win a lovely woman's wage.

We do this only for our Lord;

He also gives us our reward.

Who journeys for a woman's pay

and perishes along the way

will surely find his soul is lost.

You must consider, sir, the cost."

1326

I answered him, "God is so good, with sympathetic fatherhood, and such a noble, lofty mind.

Who serves with honor womankind need never fear that He'll object.

He wants that we should not neglect to serve them; that is His design.

This is the truth, $\mathrm{O}$ friend of mind.

"Forever more shall I be glad that my so lovely lady bade me take the trip in her employ for I have served her since a boy without her thanking me a bit. If I should hesitate with itnow that my lady's given me a task -'t would seem quite cowardly."

I329 "Since you're to follow her request (although I do not think it best) send someone now and tell her so. She'll be delighted, as I know. I'll gladly be your messenger for I've been well received by her. The lady's temperament is such, this news will please her very much."

I332 I left him and it wasn't long till I'd composed another song. I rhymed a little book beside and in its verses I replied that her command would be obeyed. More loving verse has ne'er been made than that I put into this book in which my lady was to look. 
With song and booklet he bestrode his horse and speedily he rode to bring them to my lady fair. He got a hearty welcome there. She spoke, "Good youth, tell me, I pray. docs he intend to earn his pay by going to that distant land and thus fulfilling my command?"

"He sends me, lady, here to you. His heart's desire is just to do you service; nothing will he shun and everything be gladly done. He's ready for the pilgrimage for this I'll pledge my soul as gageand is quite happy. It is plain, no task he does for you is pain.

"He sent to you, my lady dear, by me this little booklet here and sent a song, both new and gay. $\mathrm{He}$ asked me when I rode away to put them both into your hand. The booklet lets you understand, he'll make the journey 'cross the sea for you with constant loyalty."

She took them and when she had read all that the little booklet said she found it pleased her very well. And this is why I now can tell you that my lady good and wise read with bright and shining eyes without delay and greatly cheered the page on which the song appeared.

I338 When she had read it to the end she went at once back to my friend and spoke, "I always shall accord my thanks, and rightly, to your lord because he thinks so well of me that he will do and eagerly whate'er I ask. That does him good and I'll reward him as I should. 
"Ask of him that he prepare to make the journey and with care so that when I shall let him know he will be ready and can go. I want to see your lord again and will arrange a time ere then. He needn't be concerned thereby; as I'm a woman, it's no lie."

He left the lady and returned, but I had travelled on, he learned. ' $T$ was in Vienna that he found me where I'd gone to look around. I saw there many a pretty maid and lovely lady, well arrayed, and thoroughly enjoyed the sight; it makes one's heart feel warm and light.

When I beheld the messenger I welcomed him and asked of her. He let me know without delay all that she wanted him to say. I was prepared for nothing less and did not lack in faithfulness. It pleased me so that she'd consent to see me once before I went.

In tournaments the summer through I jousted and it's surely true that I had tied my helmet on a lot of times ere it was gone. With tilts I served my lady fair most willingly and everywhere until the winter came once more and all the tourneying was o'er.

"Good Lord, when will it be," I thought, "till she for whom I've often fought sends me the message I await?

How am I going to know the state after these months of her regard?

To wait around is pretty hard; I'd like to hear from her somehowwould God, a messenger came now!" 
She had somebody go and find my messenger and was so kind to quickly send him on to me; he told me all and faithfully. The message that he brought was such that I'm afraid I'll say too much and so I'll stop ere something slips for chivalry must close my lips.

But that which afterwards befell is something I'm allowed to tell. The lady said, I shouldn't take the distant journey for her sake; the virtuous and lovely dear wanted me to stay right here. My lover's sorrow now was goneand then the summer too came on.

I35I My heart was happy and at ease; I sang two summer melodies, a march and then another song. I'd been an orphan for so long but joy can make the spirit wholeI felt it in me, and my soul could barely hold its secret bliss.

Now hear! The verses go like this:

THE SIXTEENTH IS A MARCH

He who with honor would pass the time gaily, would know true delight and enjoy himself daily should faithfully serve a fair lady of station for love's compensation. Its sweetness and splendor will only surrender to those kind and tender. 
Who courts as a knight and hopes for successes must give heart and hand and the goods he possesses, but love will reward him with wealth beyond measure, so great is her treasure.

She honors, appeases

her pupil and eases

his care as she pleases.

Knighthood demands both good manners and daring, dishonor, deceit, and its fellows forswearing, for God can't endure in his service the babble of such wretched rabble.

His men must endeavor to find honor ever and infamy never.

Malice and coarseness, ill nature and scheming to neither the shield nor the helmet is seeming, for knighthood's a roof that no evil can cover. Its glance shall discover the honorless, fearful, the frightened, half-tearful where brave men are cheerful.

High-minded ladies, remember with favor the faithful companion whose heart will not waver. Love him in your thoughts and with all your affection that thus your protection may keep with the power of love him each hour from griefs that devour.

Through no fault of mine is the lady offended, though I am her knight and for her have contended. And now for protection from anger and sorrow no shield can I borrow but one: I still love her and think kindly of her. None else is above her. 
I'll battle with patience her warlike resistance, opposing her anger with guileless insistence. Protected because I am faithful and loyal, all falsehood I'll foil. My battle attire against her dread fire is constant desire.

Singing this song with heart so light that summer many a gallant knight went jousting, that was their way of life; they served their ladies with this strife. Believe me when I say to you, there were tournaments the summer through in every country, here and there. I didn't miss a one, I swear.

The summer was very summery and full of summer gaiety. It grew in summer's strength and power but still was squandered, hour by hour, for ladies with chivalric sport.

The noble knights of every court used up their weapons tourneying as if the spears weren't worth a thing.

That summer the lady did to me an awful thing. If it might be a knight could tell to you this tale the honest folks would help him wail that a lady could ever so offend and wound her faithful knight and friend. Her action was so mean and small I never could lament it all.

I362 When with hoarfrost, cold and keen, the fall destroyed the forest green and when the heath had lost its gay attire which it had donned in May of flowers - every hue and kindand when the summer had declined and stealthily had fled away, I sang this melancholy lay: 


\section{THE TWENTIETH DANCE TUNE}

You noble ladies, so refined and lovely, take my part; before you all do I accuse the mistress of my heart for she has robbed me so of joy and left me only pain that because of her I must evermore complain.

I grieve that she'll not recognize my service, as is right, although I've served her long and truly like a faithful knight. That she is praised so highly everywhere by many a tongue is because I've spread her fame with the songs I've sung.

I charge my lady with committing theft and robbery, for it is robbery and theft (what other could it be?) that she should seize my happiness without declaring war and deprive my heart of joys, all for evermore.

I say she is a robber and is guilty of a theft so great I'll ne'er replace the things of which I am bereft. If she should give me back enjoyment, which she can and may, yet imagine what I've lost: many a lovely day.

Because of her I suffer more than I can tell or share from agonizing, yearning pangs which secretly I bear. Alas! Alas, that she was born to cause me such distress, she whose love I most of all wanted to possess.

Were I not silenced by good manners and by hopes of love, Then you'd believe, because of all the things she robbed me of (should I reveal my longing heart and give each crime a name), that the color of her face would turn red with shame.

If anyone can reconcile us this would please me so I'd not be angry anymore nor burdened down with woe, no one would hear me say of her a word of censure then and, whate'er she later does, this, at least, has been. 
When my lady heard this song she wouldn't try to right the wrong but did a thing which hurt a lot though I shall never tell you what. Even today and more and more with suffering my heart is sore; I won't reveal the reason why but keep her secret till I die.

1364

Alas, that she would do this thing! Alas, that I should ever sing of her in anger as I've done, so that long after many a one condemned this book and also me who did not know the cruelty with which my honest love was spurned, nor with what deeds my wrath was earned.

Since she continued these affronts

I gave up serving her at once and turned away both mind and heart. Who from long service does not part when one gives no reward, nor can, is really quite a foolish man.

My service went for nought or lessI sang this song in bitterness:

$\mathrm{O}$ to lose and to regret that which I cannot forget evermore!

Joy and all my better daysgone with melancholy lays.

Wounded sore, I must bear life given o'er to grieving care: death is less than such distress. 
There my service was to be with such constant loyalty through the years.

Still no pay will she accord and no prospect of reward.

O my tears!

$\mathrm{O}$ ! and $\mathrm{O}$ !

Had I hopes, as long ago,

I could then

laugh again.

She once filled me with delight when she let me be her knight and for life.

I did not complain a bit at that time, I must admit without strife.

But so small is the thanks which she lets fall that we're poorboth-that's sure.

Many years, I see with pain, I have squandered all in vain for someone who can never fully pay me for just a single day that is done, since her mind is no more so good and kind as when she conquered me.

She was beautiful and true, she was lovely through and through when I chose her to be the lady fair whom I honored everywhere, as she knows.

Then her name was exalted without shame; later on thanks was gone. 
Thus she discovered from this song that, though I'd served her well and long, I would not serve her anymore.

Alas for this! Alas therefor, that she should deal to me the blow for which I'd have to leave her so and that it ever might occur to me to speak so ill of her.

Now tell me if you think I had good reason to be very sad that I could not be reconciled to one I'd worshipped as a child. I had to tell her thanklessness though I'd have suffered less distress if I had perished, I believe.

Such loss and pain was mine to grieve.

No gracious ladies, I know well, will censure me because I tell how much my lady did me ill. If it depended on my will to keep it secret that I'd do. No one should claim that I'm untrue. She well deserves that I have turncd from her; it's what her deeds have earned.

I376 I did not scold her anymore nor did I serve her as before, and after what she did to me I was a while quite lady-free down to the bottom of my heart. But I could not neglect my art nor leave off singing women's praise. I sang of love and happy days: 
In the warm and fragrant Maytime when the woods are dressed in green through the happy hours of daytime all that loves in pairs is seen.

Every heart is filled with bliss and the spring was made for this.

Loving pairs in pleasant hours soon are free from all distress; in the hearts of both there flowers all the season's happiness.

Sorrow love cannot abide when two loves are side by side.

When two loving hearts are plighted faithfully without deceit, when the two are so united that their love must be complete, they are joined by God to capture all that life can hold of rapture.

Constant love is minne. Truly love and minne are the same. l cannot distinguish duly ought between them but the name nor can tell the two apart.

Love is minne in my heart.

Find a heart that does not vary, constant love and constant mind, then with grief you can be merry. Constant love is good and kind and to constant hearts will give constant pleasure while they live.

If I ever found enduring love then I would surely be always loyal, with it curing all the cares that come to me. Faithless love will never do, I must find a love that's true. 



\section{BIBLIOGRAPHY}

The following works have been consulted. Further information concerning most of these works can be found in

Carl von Kraus, ed. Deutsche Liederdichter des 13. Jahrhunderts, vol. II (Tübingen, 1958), pp. 519-520.

The following abbreviation has been used in the Bibliography: ZfdA, Zeitschrift für deutsches Altertum und deutsche Literatur.

Abert, A. "Das Nachleben des Minnesangs im liturgischen Spiel," Musikforschung, I (I948), 95-I05.

Arens, Hans. Ulrichs von Lichtenstein "Frauendienst." Untersuchungen über den höflichen Sprachstil. Leipzig, 1939.

Review by Arthur Witte, Literaturblatt für germanische und romanische Philologie, vII-VII (1942), 190-196.

Bartsch, Karl and Wolfgang Golther, eds. Deutsche Liederdichter des 12.-14. Jahrhunderts. Berlin, 1928, pp. lvii-lviii.

Bechstein, Reinhold, ed. Ulrich's von Liechtenstein Frauendienst. 2 vols. Leipzig, 1888. Review by Anton Schönbach, Deutsche Literatur Zeitung, Ix (1888), I I I 2-I I 14.

Becker, Anton. "Der Weg der Venusfahrt in Niederösterreich," Monatsblatt des Vereins für Landeskunde von Niederösterreich, xxrv (1925), 34-43.

Becker, Reinhold. Ritterliche Waffenspiele nach Ulrich von Lichtenstein. Programm des Dürener Realprogymnasiums, No. 458. Düren, 1887.

Becker, Reinhold. Wahrheit und Dichtung in Ulrich von Lichtensteins Frauendienst. Halle, I888.

Beckh-Widmanstetter, L. von. Ulrichs von Liechtenstein, des Minnesängers, Grabmal auf der Frauenburg. Graz, 1871 .

Beckh-Widmanstetter, L. von. "Das Grabmal auf der Frauenburg," Tagespost. Graz, No. 274 (Oct. 13, 1871).

Bodmer, J. J. and J. J. Breitinger, eds. Sammlung von Minnesingern aus dem schwäbischen Zeitpunkte. Vol. II. Zürich, 1759, pp. 24-46.

Boor, Helmut de. Geschichte der deutschen Literatur. Vol. II. München, 1953, pp. 337-346. Vol. UI. München, 1957, pp. 313-319.

Bouterwek, Friedrich. Geschichte der Poesie und Beredsamkeit seit dem Ende des 13. Jahrhunderts, ix. Göttingen, I812.

Brecht, Walther. "Ulrich von Liechtenstein als Lyriker," $Z f d A$, $\operatorname{xLIX}(1908), \mathrm{I}-\mathrm{I} 22$. Review by Anton Schönbach, Allgemeines Literaturblatt, xvI (1907), 749-752.

Bruder, Annemarie. Studien zu Ulrich von Liechtensteins "Frauendienst." Diss. Freiburg, 1923.

Bub, Felix. Beiträge zur Genealogie und Geschichte der steierischen Liechtensteine. Graz, 1902.

Ehrismann, Gustav. "Die Grundlagen des ritterlichen Tugendsystems," ZfdA, LVI (1918), 137-216.

Ehrismann, Gustav. Geschichte der deutschen Literatur bis zum Ausgang des Mittelalters. Vol. n, 2. München, 1935, pp. 262-265.

Falke, Jacob. Geschichte des fürstlichen Hauses Liechtenstein. Vol. I. Wien, I868, pp. 57-I24. 
Falke, Jacob. "Ein alter Grabstein," Tiagespost. Graz, No. 267 (Oct. 6, 1871).

Gennrich, Friedrich, Troubadours, Trouvères, Minnesang und Meistergesang. Köln, 1960, p. 71 . Goedeke, Karl, ed. Grundriss zur Geschichte der deutschen Dichtung. Vol. I. Dresden, 1894, pp. 168-170.

Görner, Otto. "Ulrich von Lichtenstein in Zerbst," Mitteldeutsche Blätter für Volkskunde, v (1930), 33-48.

Grimme, Friedrich. "Beiträge zur Geschichte der Minnesänger II," Germania, xxxII (I887), 4II-427.

Grimme, Friedrich. "Zum Leben Ulrichs von Lichtenstein," Germania, xxxv (1890), 406-407.

Hagen, Friedrich von der, ed. Minnesinger: Deutsche Liederdichter des 12. 13. und 14. Jahrhunderts, 5 vols. Leipzig, 1838-1861.

Vol. I, pp. 32-62. Vol. III, pp. 657-661. Vol. IV, pp. 32I-405.

Haupt, Moriz. “Urkundliches zu Mittelhochdeutschen Dichtern," ZfdA, vu (1849), 168-169.

Hauptmann, Gerhart. Ulrich von Lichtenstein. Komödie. Berlin, 1939.

Höfler, Otto. "Ulrichs von Liechtenstein Venusfahrt und Artusfahrt," Studien zur deutschen Philologie des Mittelalters. Ed. Richard Kienast. Heidelberg, 1950, pp. I 3 I-1 52.

Hösele, Alfred. "Ulrich von Lichtenstein. Der Roinan eines Minnesängers," Jahresbericht des Gymnasiums Carolinum-Augustineum. Graz, 1954, 3-I I.

Huisman, J. A. NeueWege zur dichterischen und musikalischen TechnikWalthers von der Vogelweide. Utrecht, 1950, p. 147.

Kalchberg. "Ulrich von Lichtenstein. Geschichtlich untersucht," Wöchentliche Nachrichten für Freunde der Geschichte, Kunst und Gelahrtheit des Mittelalters, I (1816), 47-50. II (1816), $231-234$.

Knorr, Karl. Über Ulrich von Lichtenstein. Quellen und Forschungen zur Sprach- und Culturgeschichte, Vol. Ix (Strassburg, I875). Review by Otto Behaghel, Germania, xxI (1876), 434-436.

Kosch, Wilhelm. Deutsches Literatur-Lexikon. Vol. Iv. Bern \& Miinchen, ro58, pp. 30843085 .

Kracher, Alfred. "Der steierische Minnesang," Zeitschrift des historischen Vereins für Steiermark, xLVII (1956), 123-137.

Kraus, Carl von, ed. Deutsche Liederdichter des 13. Jahrhunderts. 2 Vols. Tübingen, 19521958. Vol. 1, pp. 428-495. Vol. I, pp. 519-558.

Kuhn, Hugo. Minnesangs Wende. Tübingen, 1952. Hermaea. Vol. I, pp. 85-87.

Kummer, Karl F., ed. Die poetischen Erzählungen des Herrand von Wildonie und die kleinen innerösterreichischen Minnesinger. Wien, 1880, pp. 21-26, 47-52.

Lachmann, Karl, ed. Ulrich von Lichteristein. Mit Anmerkungen von Theodor von Karajan. Berlin, I841.

Langenbucher, Hellmuth. Das Gesicht des deutschen Minnesangs und seine Wandlungen. Heidelberg, 1930, pp. 69-70.

Lichtenstein, Franz. Review of: Felix Niedner, Das Deutsche Turnier im XII. und XIII. Jahrhundert. Anzeiger für deutsches Altertum, vur (1882), 14-19.

Lind, K. "Ulrich's von Lichtenstein, des Minnesängers Grabmal auf der Frauenburg," Mitteilungen der kaiserlichen königlichen Zentralkommission für Denkmalpflege, XvII (1872), 102-103.

Loehr, Maja. "Die Grabplatte auf der steirischen Frauenburg und die Ruhestätte Ulrichs von Liechtenstein," Mitteilungen des Instituts für österreichische Geschichtsforschung, LXv (1957), 53-70.

Lucas, Wilhelm. Das Adjektiv bei Ulrich von Lichtenstein. Diss. Greifswald, IOI 4.

Lunzer, J. "Stejermark in der deutschen Heldensage," Sitzungsberichte der Akademie der Wissenschaften in Wien, ccIv (1929), I-196.

Millot, Claude François. Histoire Littéraire Des Troubadours, III. Paris, 1774, pp. 127-1 28.

Milnes, Humphrey. "Ulrich von Lichtenstein and the Minnesang," German Life and Letters, XVII (1963-1964), 27-43. 
Minis, Cola. "Ulrich von Lichtenstein," Die Deutsche Literatur des Mittclalters. Verfasserlexikon. Vol. v. Ed. Karl Langosch. Berlin, 1955, pp. 1098-1099.

Misch, Georg. Geschichte der Autobiggraphie. Vol. Iv, 1. Frankfurt a. M., 1967, pp. 433-437. Morgan, Bayard Quincy. A Critical Bibliography of German Literature in English Translation, 1481-1927. Stanford, 1938, p. 491.

Morgan, Bayard Quincy. A Critical Bibliography of German Literature in English Translation. Supplement, 1928-1955. New York \& London, 1965, p. 486.

Müller, Günther. "Strophenbindung bei Uirich von Lichtenstein," ZfdA, Lx (1923), 33-69.

Ncumann, Fricdrich. "Ulrich von Lichtensteins Fraucndienst. Eine Untersuchung uiber das Vcrhältnis von Dichtung und Leben," Zeitschrift fiir Deutschkunde, XL (I926), 373-386.

Nigg, Mariannc. Zum Gedächtnis an den Minnesänger und Dichter Ritter Ulrich von Lichtenstein zu seinem 700. Geburtsjahre. Korneuburg, 1899.

Ortner, M. "Ulrich von Lichtenstein und Steinmar," Germania, xxxu (1887), I 20-125.

Ottokars Österreichische Reimchronik. Ed. Josef Scemüller. Monumenta Germaniae Historica, Deutsche Chroniken. Vol. v, pts. I \& 2. Hannover, I 890-1893, 11. I97I f., 2296f., 5944 f., 6002 f., $6012 f$., 6027 f., 6059 f., 9866 f., 9878 f., 9905 f., 9997 f., 1000I f., 100I 5 f., 1005 If., 10058f., 10539f.

Pctzet, Erich and Otto Glauning, eds. Deutsche Schrifttafeln des IX. bis XVI. Jahrhunderts. Vol. III. München, 1912, Tafel xxxvi.

Pfaff, Fridrich, ed. Die Grosse Heidelberger Liederhandschrift. Heidelberg, 1909, pp. 771-823.

Pfaff, Fridrich, cd. Der Minnesang des 12.-14. Jahrhunderts. Vol. I. Stuttgart, 1892, pp. 133142.

Pfeiffer, Franz, cd. Die Alte Heidelberger Liederhandschrift. Hildesheim, 1962, pp. 126-127, 258.

Puff, Rudolf. "Beiträge zur Geschichte des ritterlichen stcirischen Sängers Ulrich von Lichtenstein," Prograntm des Staatsgymnasitms in Marburg. Marburg, 1856, pp. I-1 I.

Reuschel, H. "Ulrich von Lichtenstein," Die Deutsche Literatur des Mittelalters. Verfasserlexikun. Vol. Iv. Ed. Karl Langosch. Berlin, 1953, pp. 584-589.

Rödiger, Max. "Zu Ulrichs von Lichtenstein Büchlein," ZfdA, XXII (1878), 380-382.

Ruhemann, Alfred. "Einleitung," Frauendienst, oder Geschichte und Liebe des Ritters und Sängers Ulrich von Lichtenstein. Tr. Ludwig Tieck. Volksbibliothek für Kunst und Wissenschaft, Abtlg. Varia, Heft 213. Leipzig, 1885, pp. I-3.

Rust, Werncr. Freud und Leid in Ulrich von Lichtensteins Frauendieist. Diss. Greifswald, I918.

Scherer, Wilhelm and Oskar Walzcl. Geschichte der deutschen Literatur. 4th ed. Leipzig, 1928 , pp. 162-163.

Scherer, Wilhelm "Der Kürenberger," ZfdA, xvII (1873), 56I-58I.

Schlereth, Martha. Studien zu Ulrich "on Lichtenstein. Diss. Wuirzburg, 1950.

Schmidt, Erich. Reinmar von Hagenail und Heinrich von Rugge. Qucllen und Forschungen zur Sprach- und Culturgeschichte. Vol. IV (Strassburg, 1874), pp. I16-I 20.

Schneider, Karl Ludwig. "Die Selbstdarstellung des Dichters im Frauendienst Ulrichs von Lichtenstein," Festgabe für Ulrich Pretzel. Berlin, 1963, pp. 216-223.

Schönbach, Anton. "Zu Ulrich von Lichtenstein," $Z f d A$, XXV1 (1882), 307-326.

Schönbach, Anton. "Ulrich von Licchtenstein," Allgemeine deutsche Biographie. Vol. xvill. Lcipzig, 1883, pp. 620-623.

Schönbach, Anton. "Zum Fraucndienst Ulrichs von Liechtenstcin," Zeitschrift für deutsche Philologie, xxvmI (1896), 198-226.

Schönbach, Anton. "Zu Ulrich von Liechtenstein," Anzeiger fïr deutsches Altertum, xxix (1904), 277-278.

Schopf, A. W. "Die Töne Uolrichs von Liehtenstcin [sic]," Viertes Programmn des K. K. kathol. Gymnasiunis zu Pressburg. Pressburg, I854, pp. 3-16.

Schröder, Edward. "Herrand von Wildon und Ulrich von Lichtenstein," Göttinger Nachrichten, I923, pp. 33-62.

Schröder, Edward. "Zur Texckritik Ulrich von Lichtensteins," ZfdA, LXIX (1932), 323-332.

Silberstein, August. Denksäulen im Gebiet der Cultur und Literatur. Wien, 1879, pp. 79-163.

Sprenger, R. “Zu Ulrichs von Lichtenstein Fraucndienst," Germania, xxxvII (1892), 174-I 80. 
Tieck, Ludwig, tr. Minnelieder aus dem schuäbischen Zeitalter. Berlin, 1803, pp. I26-144.

Tieck, Ludwig, tr. Frauendienst, oder Geschichte und Liebe des Ritters und Sängers Ulrich von Lichtenstein. Stuttgart \& Tübingen, 1812.

Touber, A. H. "Der literarische Charakter von Ulrich von Lichtensteins Frauendienst," Neophilologus, II (1967), 253-262.

Uhland, Ludwig. Schriften zur Geschichte der Dichtung und Sage. Vol. v. Stuttgart, I870, pp. 210-244.

"Alte steierische Gedichtsfunde und Dichter. II. Herr Ulrich von Liechtenstein" (anon.), Tagespost. Graz, No. 269 (Nov. 24, I864).

Utz, Franz. Das Moralsystem bei Ulrich von Lichtenstein. Diss. Greifswald, 1920.

Wackernagel, Wilhelm. Geschichte der deutschen Literatur. Vol. 1, 2. Basle, 1889, p. 285.

"Wandelhalle der Bücherfreunde" (anon.), Zeitschrift für Bücherfreunde, xxxvII (1933), I53.

Weinhold, Karl. Über den Antheil Steiermarks an der Deutschen Dichtkunst des Dreizehnten Jahrhunderts. Almanach der Akademie der Wissenschaften. Wien, 1860, pp. 18-23.

Werner, Richard Maria. Review of: Ferdinand Michel. Heinrich von Morungen und die Troubadours. Anzeiger für deutsches Altertum, vII (1881), I2I-I 5I.

Wilmanns, Wilhelm. Review of: Konrad Burdach, Reinmar der Alte und Walther von der Vogelweide. Ein Beitrag zur Geschichte des Minnesangs. Anzeiger für deutsches Altertum, vII (I88I), 258-273.

Wilmanns, Wilhelm. Review of: Rumpelt, Das natürliche System der Sprachlaute. Sokrates: Zeitschrift für das Gymnasialwesen, xXIV (1870), 578-602.

Woratschek, Margareta. Eine Reimuntersuchung zu Ulrich von Lichtenstein: Frauendienst und Frauenbuch. Diss. Wien, 1956.

Zahn, “Der Frauenburger Grabstein," Tagespost. Graz, No. 279 (Oct. 18, 1871).

Zitzenbacher, Walther, tr. Ulrich von Liechtenstein. Narr im hohen Dienst. Graz \& Wien, 1958.

Zois, Michelangelo, tr. Der Frauendienst des Minnesängers Ulrich von Liechtenstein. Stuttgart, 1924. 



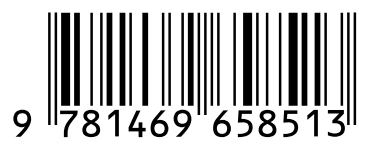

